\title{
WestVirginiaUniversity
}

THE RESEARCH REPOSITORY @ WVU

Graduate Theses, Dissertations, and Problem Reports

2002

\section{Three essays on trade policy and factor mobility}

\author{
Baishali Majumdar \\ West Virginia University
}

Follow this and additional works at: https://researchrepository.wvu.edu/etd

\section{Recommended Citation}

Majumdar, Baishali, "Three essays on trade policy and factor mobility" (2002). Graduate Theses, Dissertations, and Problem Reports. 1711.

https://researchrepository.wvu.edu/etd/1711

This Dissertation is protected by copyright and/or related rights. It has been brought to you by the The Research Repository @ WVU with permission from the rights-holder(s). You are free to use this Dissertation in any way that is permitted by the copyright and related rights legislation that applies to your use. For other uses you must obtain permission from the rights-holder(s) directly, unless additional rights are indicated by a Creative Commons license in the record and/ or on the work itself. This Dissertation has been accepted for inclusion in WVU Graduate Theses, Dissertations, and Problem Reports collection by an authorized administrator of The Research Repository @ WVU.

For more information, please contact researchrepository@mail.wvu.edu. 


\title{
Baishali Majumdar
}

\author{
Dissertation Submitted to the \\ College of Business and Economics \\ at West Virginia University \\ in partial fulfillment of the requirements \\ for the degree of \\ Doctor of Philosophy \\ in \\ Economics
}

Subhayu Bandyopadhyay, Ph.D., Chair

Ashok B. Abbott, Ph.D.

Stratford M. Douglas, Ph.D.

Ming-Jeng Hwang, Ph.D.

Russell S. Sobel, Ph.D.

Department of Economics

Morgantown, West Virginia

2002

Keywords: Transfers, Immigration, Liberalization

Copyright 2002 Baishali Majumdar 


\title{
ABSTRACT \\ THREE ESSAYS ON TRADE POLICY AND FACTOR MOBILITY
}

\author{
Baishali Majumdar
}

This dissertation consists of three essays on trade policy and factor mobility. The first essay of the dissertation deals with issues on trade policy. It focuses on the possibility of recipient immiserization under optimal export taxation in a multi-country framework. We find asymmetry between two nations is very crucial for recipient immiserization. The interesting finding is that being more aggressive in taxation is a disadvantage in gaining from receipts of transfers. The larger exporter exercises more market power and is also more vulnerable to the adverse welfare effects of transfer.

The second and third essays explore the issues of trade policy as well as factor mobility. Process of trade liberalization is discussed in both essays. Factor mobility is described in the form of labor movement. In particular the two essays talk about migration. The second essay discusses illegal immigration between Mexico and the U.S. and how trade liberalization affects the flow of illegal immigrants. Results show that trade liberalization in Mexico reduces the undocumented labor flow from Mexico to the U.S. The focus of the third essay is on legal immigration to the U.S. from seven different source countries. We analyze the importance of push factors e.g. low GNP, high unemployment rate and increasing population for the level of legal immigration. Obviously, the key push factor is the tariff rate. We find that trade liberalization in the seven source countries impedes the flow of legal immigration to the U.S. In addition, growing population of the origin countries is found to stimulate the flow of legal immigration, whereas a higher GDP at origin reduces the flow of legal immigration. 
For Ma, Papa and Shonu 


\section{ACKNOWLEDGEMENTS}

As I come to the completion of my dissertation, I treasure the contributions of several individuals. This work would not have been a reality without their support. I would like to take this opportunity to thank them.

First and foremost, I would like to express my sincere gratitude to my dissertation advisor, Dr. Subhayu Bandyopadhyay. It's been a privilege to know and work with Dr. Bandyopadhyay. His sharp ideas and mathematical ingenuity have been a continuous source of motivation. I would like to thank him for the encouragement he has provided and the confidence he has shown in me. He has been extremely generous with his time and always ready to answer my questions and provide me guidance. I am deeply grateful for the commitment he has shown to improve the quality of my dissertation.

I extend my profound appreciation to the rest of my committee members; Dr. Abbott, Dr. Hwang, Dr. Sobel and Dr. Douglas. They have provided invaluable comments and suggestions in various aspects of my dissertation. Thanks to all of you for your time and guidance.

I would like to acknowledge the outstanding guidance of Dr. Jon Vilasuso in the early part of my dissertation. I will always remember his enthusiasm in research work. I owe him a special debt of gratitude for his encouragement.

Special thanks go to our program assistant Barbara Michniak. Barb thanks a lot for providing me all kind of assistance whenever I needed. I would also like to thank Dr. Ron Balvers for being very supportive.

I owe special thanks to my dearest friends, Ancy and Dhanu for their love and support. I value you friendship tremendously.

My appreciation for my family cannot be expressed in words. I could not be the person I am today, without the love, support and sacrifices of my parents (Ma and Papa). They instilled in me a value of education that made me accomplish this difficult task. Without their blessings it would have been impossible for me to overcome all the hurdles. I would like to thank them for giving me this opportunity to make them proud. My dearest brother (Mainak) has always given me tremendous love and caring in his own quiet way. I know how happy you are for me. My dear little Gutun, you are like a brother to me. You have brought so much joy in my life. I am very fortunate to have an aunt like my Masi and a grandmother like my Didu. I have received immense love from them all my life. They had a great aspiration that I earn my doctoral degree successfully. Finally, I would like to thank my dear husband (Shonu). The unstinting support, encouragement, love and patience of my husband made me come this long way. He made me believe that I can finish my dissertation. He always kept me focused towards my goal and never let me get too discouraged. He is the one who truly understood and experienced the crests and troughs along with me in the accomplishment of this work. 


\section{TABLE OF CONTENTS}

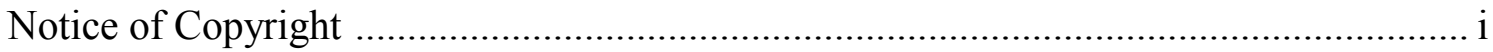

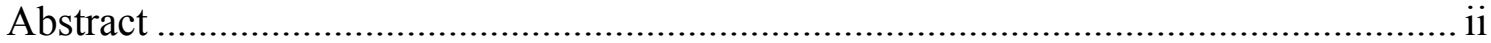

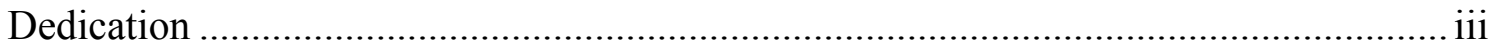

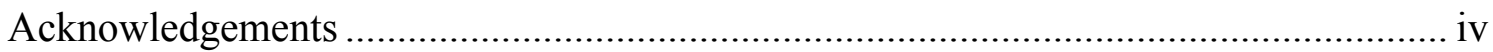

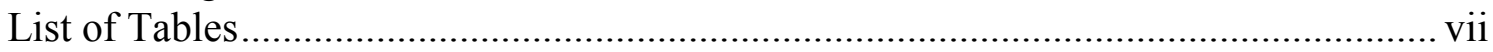

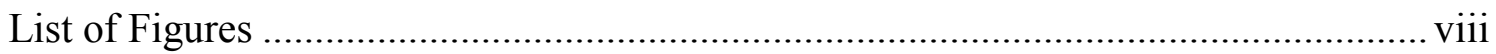

Chapter 1:

Introduction, Review of the Literature, and Overview of the Dissertation ....................... 1

Chapter 2:

The Transfer Paradox in a Multi Country framework ..................................................... 5

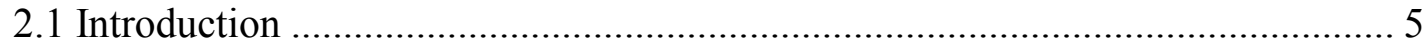

2.2 The Model with Nash Welfare Maximizing Taxes ......................................... 10

2.3 Some Useful Welfare and Price Effects ........................................................... 12

2.4 The Case of Bilateral Transfers ..................................................................... 14

2.5 The Case of Multilateral Transfers ................................................................. 17

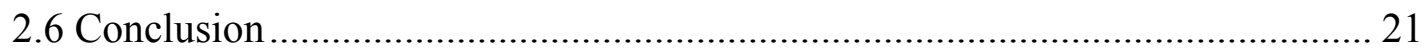

2.7 Simulation Results Supporting Multilateral Transfer....................................... 23

2.8 Mathematical Derivations Supporting the Text................................................ 28

Chapter 3:

Trade Liberalization and Illegal Immigration between Mexico and the United States... 33

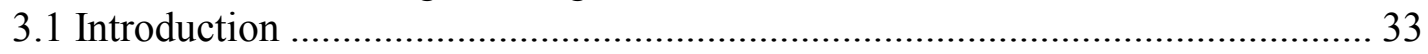

3.2 Illegal Immigration: The Policy Debate ……………………………………... 35

3.3 Mexican Maquiladora System and Its Impact on Illegal Immigration ............... 38

3.4 Trade Liberalization as Captured in NAFTA ………………………................. 39

3.5 Trade Liberalization and Illegal Immigration: What are the Linkages................ 41

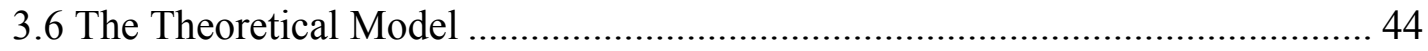

3.7 The Empirical Model.................................................................................. 47

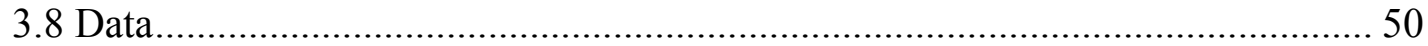

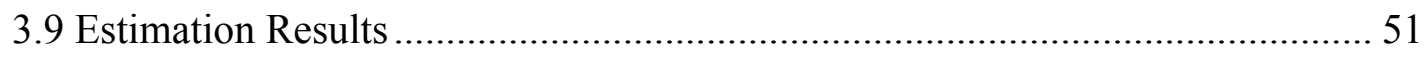

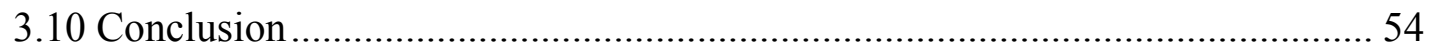

Chapter 4:

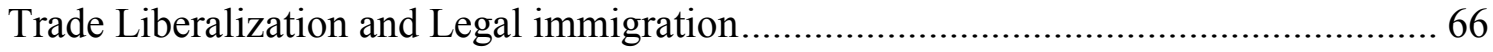

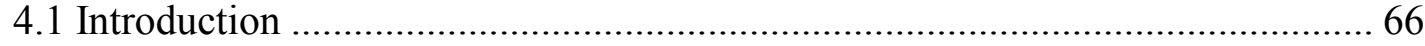

4.2 Legal Immigration, Immigration Laws and Related Basic Concepts ................. 68

4.3 Trade Liberalization as Experienced by Countries in Our Sample .................... 72 


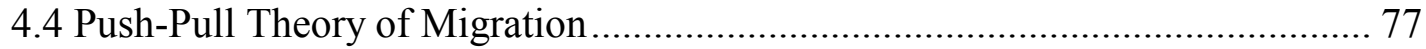

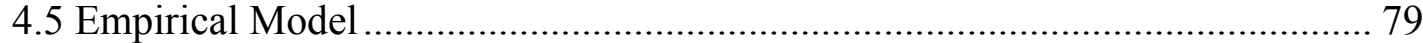

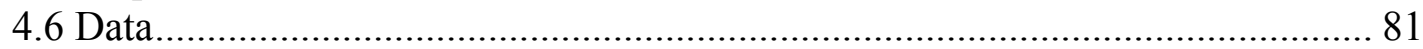

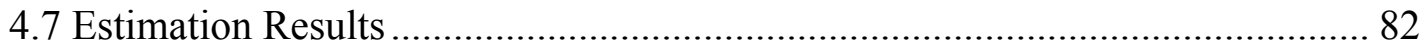

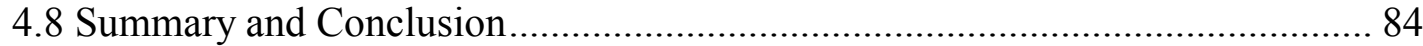

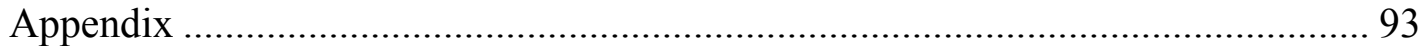

Chapter 5:

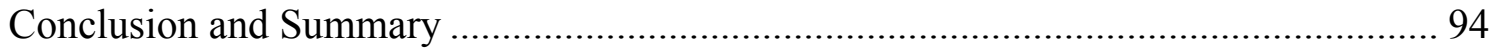

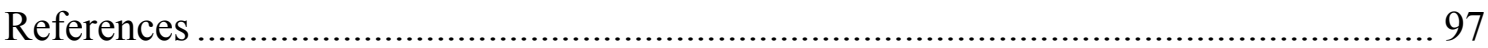




\section{List of Tables}

Table 3.1: First AR(1) Specification of Border Apprehension with Border Patrol Budget as Enforcement Measure 56

Table 3.2: Second AR(1) Specification of Border Apprehension with Border Patrol Budget as Enforcement Measure ......................................................................... 57

Table 3.3: Third AR(1) Specification of Border Apprehension with Border Patrol Budget as Enforcement Measure.

Table 3.4: Fourth AR(!) Specification of Border Apprehension with Border Patrol Hours as Enforcement Measure................................................................................... 59

Table 3.5: Fifth AR(1) Specification of Border Apprehension with Border Patrol Hours as Enforcement Measure

Table 3.6: Sixth AR(1) Specificaion of Border Apprehension with Border Patrol Hours as Enforcement Measure

Table 3.7: First Difference Specification of Border Apprehension ............................... 62

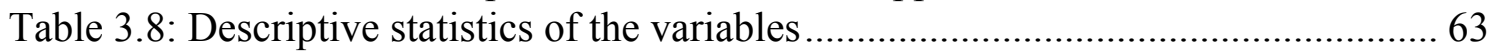

Table 4.1: The Immigration Act of 1990 .................................................................... 71

Table 4.2: OLS, Fixed Effect and GLS Estimation of the first model ............................ 86

Table 4.3: OLS, Fixed Effect and GLS Estimation of the second model ....................... 87

Table 4.4: OLS, Fixed Effect and GLS Estimation of the third model ........................... 88

Table 4.5: OLS, Fixed Effect and GLS Estimation of the fourth model........................ 89

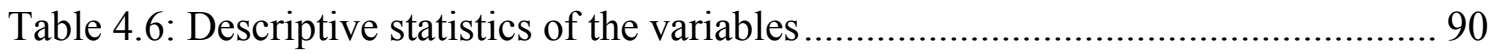




\section{LIST OF FIGURES}

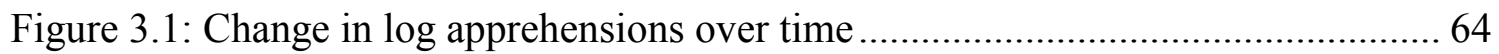

Figure 3.2: Change in log border patrol budget over time .............................................. 64

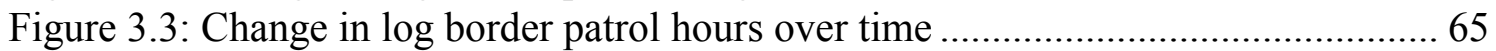

Figure 3.4: Change in Log Mexican and Log U.S. tariff rates over time........................ 65

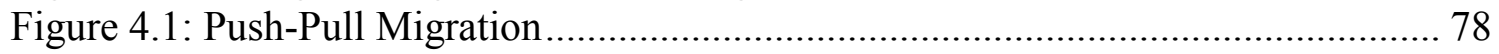

Figure 4.2: Legal Immigrants ............................................................................ 91

Figure 4.3: Origin Tariff Rate for Selected Economies ................................................ 92

Figure 4.4: Origin Tariff Rate for Selected Economies ................................................. 92 


\section{Chapter 1}

\section{Introduction, Review of the Literature, and \\ Overview of the Dissertation}

This dissertation presents three essays on trade policy and factor mobility. Chapter 1 is an introductory chapter that gives an overview of the dissertation and also reviews the related literature. Chapter 2 presents the first essay that deals with issues on trade policy. It discusses the issue of optimal export taxation and immiserizing transfers ${ }^{1}$. Chapter 3 and chapter 4 present the second and third essays respectively. Both essays discuss the linkage between trade policy and factor mobility. The second essay studies the impact of trade liberalization on illegal immigration. The third essay focuses on how trade liberalization affects legal immigration. Chapter 5 concludes the dissertation by reviewing the conclusions and implications from each essay.

In trade theory, optimal export taxation has traditionally been analyzed in the context of two-country general equilibrium models. However, in reality several nations export a particular commodity. For example, nations like Cote d'Ivoire and Brazil export cocoa and also employ export taxes. Clearly, the world cocoa price is dependent on the tax policies of each of these exporting nations. Hence the trade polices of the exporting nations are interdependent and the terms of trade movements for an exporting nation depends on the existing taxes (or tax policies) of the competing nations.

\footnotetext{
${ }^{1}$ Immiserizing transfer occurs when the welfare level of a nation is worsened due to receipts of transfer payments.
} 
The first essay analyzes the welfare consequences of transfers in the presence of Nash optimal taxes. In particular, we study the issue of immiserizing transfers. Immiserizing transfers occur when an induced adverse terms of trade effect on the recipient exceeds the primary gains of transfer itself. Samuelson (1947) argues that immiserizing transfer can be ruled out in a two-country framework if the international market equilibrium is stable. However, Bhagwati, Brecher and Hatta (1983) show that the immiserizing transfer paradox cannot be ruled out in a multi-country context. The presence of a third country can lead to an amplified adverse terms of trade movement that outweighs the primary gains of transfers and results in recipient immiserization (consistent with market stability).

We adopt a three-country (A, B and C) two-good (1 and 2) framework where domestic consumption of the export good is allowed. Nation A and B export good 1 to nation C and impose optimal taxes on their export good. Apart from exporting good 1, A and B also consume good 2. Nation C consumes both goods but produces good 2 only. C makes transfer payments to A and B. We consider four scenarios. First, can a bilateral transfer from $\mathrm{C}$ to $\mathrm{A}$ immiserize $\mathrm{A}$ ? Second, under an equiproportionate transfer from $\mathrm{C}$ to $\mathrm{A}$ and $\mathrm{B}$ (where transfers are proportional to the exports of $\mathrm{A}$ and $\mathrm{B}$ ) is recipient immiserization possible? Third, can recipient immiserization happen when equiproportionate transfers are made by $\mathrm{C}$ to $\mathrm{A}$ and $\mathrm{B}$ where transfers are not proportional to the exports of A and B? Finally if $\mathrm{C}$ makes equal transfers to $\mathrm{A}$ and $\mathrm{B}$, can it lead to recipient immiserization? The first essay attempts to answer these questions in a general equilibrium context. 
The second and third essays study the linkage between trade policy and factor mobility. The trade policy issue studied is the process of trade liberalization. Factor mobility focuses on movement of labor. The second essay considers the impact of trade liberalization on illegal immigration. The third essay looks at how trade liberalization affects the flow of legal immigration.

Ethier (1986) and Bond and Chen (1987) are the pioneers in the literature on illegal immigration. Migration involves labor movement. Labor movement is different from capital mobility, as it does not generate in exchange a flow of payments unless wages are repatriated (see Ethier, 1986). Ethier (1986) presented a model where he studied several immigration policies and enforcement measures to reduce the level of illegal immigration. Bond and Chen (1987) extended Ethier's results by examining the optimal level of enforcement in a two-country model and also studied the effects of capital mobility.

Our essay builds on the work by Hanson and Spilimbergo (1999a), where they analyze the factors affecting illegal immigration from Mexico to the United States. The novelty of our study is to introduce trade liberalization and analyze the impact of trade liberalization on the undocumented labor flow from Mexico to the United States. The role of border enforcement in controlling illegal immigration is also discussed. The issue is addressed here both theoretically and empirically.

In a similar vein the third essay studies the effect of trade liberalization on legal immigration to the U.S. originating from seven different countries (Canada, El Salvador, 
India, Korea, Mexico, the Philippines and the United Kingdom). This essay is built on the push-pull theory of migration. It analyzes push factors such as low GNP, high unemployment rate, and increasing population in origin countries that force people to migrate. Obviously, the focus is on the tariff rate of the origin countries and how it affects the level of legal immigration to the U.S. In the immigration literature there is no existing study that has empirically analyzed the role of trade liberalization on legal immigration. This essay attempts to make some contribution by establishing a linkage between trade liberalization and legal immigration. 


\section{Chapter 2}

\section{The Transfer Paradox in a Multi Country framework}

\subsection{Introduction}

One of the interesting questions in international trade theory is the issue of immiserizing growth and immiserizing transfer. Immiserization has been studied and analyzed extensively in trade theory. Bhagwati (1958) showed that immiserizing growth occurs when an adverse movement in the terms of trade of the growing country outweighs the primary gain in the real income due to growth. The issue of immiserizing transfer is similar to immiserizing growth. Immiserizing transfer or transfer paradox occurs when the welfare level of a nation is worsened due to receipt of a transfer. This happens as the adverse movement in the terms of trade offsets the initial gain from the receipts of transfer.

Samuelson (1947) showed that stability in the international market equilibrium is sufficient to rule out the transfer paradox (i.e. immiserizing transfer) in a two-country two-good framework. One of the most notable works on the transfer issue is by Bhagwati, Brecher and Hatta (1983, henceforth referred to as BBH). They analyze the transfer problem or immiserizing transfer in a multi-country framework and show that the paradox of recipient immiserizing transfers cannot be ruled out in a multi-country framework under free trade. The presence of a non-participant third country creates conditions that make the transfer paradox possible even in the face of market stability. 
The presence of the third country can lead to adverse terms of trade effects to be magnified to such an extent that it outweighs the primary gains from the transfer for the recipient. If the recipient's marginal propensity to consume its export good is less than the donor's propensity to consume the same good, the transfer will lead to an excess supply of recipient's export good and a consequent terms of trade decline. If the nonparticipant is a net exporter of the same good and responds perversely (backward bending offer curve) to this price decline, then the excess supply becomes larger, leading to an amplified terms of trade decline, which allows the transfer paradox. The authors further show that if the two participating countries impose an optimal trade tax vis-à-vis the nonparticipant country then the paradox of immiserization cannot occur. The optimal trade tax neutralizes the adverse terms of trade effect on welfare and hence the possibility of immiserization can be ruled out.

The bilateral transfer paradox discussed above and the closely related problem of immiserizing growth, while being theoretically plausible, are generally regarded as remote possibilities. In addition, the positive experience of Asian nations in export expansion does not lend support to immiserization concerns. However, in recent years it has been recognized that terms of trade concerns are still alive for primary productexporting nations, and there is some evidence suggesting that rapid export expansion by these nations may be self-defeating. ${ }^{2}$ Several of these primary product exporting nations also employ export taxes, which affect terms of trade movements. For example, nations

\footnotetext{
${ }^{2}$ See for example Diakosavvas and Scandizzo (1991), Panagariya and Schiff (1991). For a survey of these issues see Rodrik (1995).
} 
like Cote d'Ivoire and Brazil export cocoa and also employ export taxes. Clearly, the world cocoa price is dependent on the tax policies of each of these exporting nations. Thus the trade policies of the exporting nations are interdependent and the terms of trade movement for an exporting nation depends on the existing taxes (or tax policies) of the competing nations. Panagariya and Schiff (1995) extended the analysis of trade taxes to a multicountry setting. They demonstrated that revenue-maximizing Nash taxes might lead to a higher welfare level than welfare maximizing optimal Nash taxes. Panagariya and Schiff emphasized the strategic interdependence in a multicountry context. However, they used partial equilibrium analysis in their model. Along similar lines, Bandyopadhyay (1992, 1995 and 1996) employs general equilibrium Nash export taxation models to show that immiserizing growth and investments are possible in spite of unilateral export taxation. Recently, Lahiri and Raimondos-Moller (1997a and 1997b) analyze trade policy in the allocation of foreign aid in a multi country general equilibrium model. Their analysis shows that if the donor maximizes its own welfare while deciding on the allocation of aid, and the marginal propensities to consume are the same in the two recipient countries, then a country with higher tariff will receive a lower share of the foreign aid than a country with lower tariff. However, the result is just the opposite when the donor maximizes the collective welfare of the recipient countries. These contributions provide a consistent framework within which one can address the concerns of primary product exporting nations.

In this essay, the transfer problem is analyzed with the help of a general equilibrium model in a three-country, two-good framework. This multi country setting is consistent 
with the real world, where aid is given by the multilateral agencies to several primary product- exporting developing nations. In reality, the nations vary in terms of their market share and export taxes. Thus we address the issue of asymmetry in analyzing the effects of transfer. Nations A and B export good 1 to nation C. There is a transfer of income from nation $\mathrm{C}$ to nations $\mathrm{A}$ and $\mathrm{B}$. Nation $\mathrm{C}$ specializes in the production of commodity 2. Nations A and B impose optimal tax while C follows free trade. ${ }^{3}$ This model differs from Bandyopadhyay (1992) because it incorporates domestic consumption in exporting nations.

The welfare effect on nation A due to the receipt of transfer payment can be decomposed into three parts: (a) the direct effect; (b) the indirect effect; and (c) the external effect. The direct effect is composed of two parts, one is the extra income received from nation $\mathrm{C}$ and the other is the negative terms of trade effect caused by the transfer between A and C. The indirect effect is the effect of A's transfers to the tax rate of B. Nation B being the exporting nation cuts its tax rate in response to a demand reduction of good 1 in the post transfer case, assuming a relatively high propensity to consume for nation $\mathrm{C}^{4}$ Hence, this indirect effect is likely to be negative. Third is the external effect i.e., the effect of the transfer to B on A's welfare. This is the adverse terms of trade externality created on A by C's gift to B. This external effect is absent in the case of a bilateral transfer where B receives no transfer payment. A-priori it is impossible to know the sign of the total

\footnotetext{
${ }^{3}$ This is a reasonable assumption since developed countries are unlikely to retaliate to export taxes on primary products exported primarily by developing nations.

${ }^{4}$ Good 1 is consumed by all the three nations. In the post transfer situation if the marginal propensity to consume of $\mathrm{C}$ (now with a lower income) is higher than that of $\mathrm{B}$ then there is a reduction in net demand of good 1 .
} 
effect. Hence we need to analyze in detail the bilateral and the multilateral case.

First, consider a bilateral transfer (where $\mathrm{C}$ makes a transfer to $\mathrm{A}$ ), where we have the direct and indirect effects of transfer. As discussed above, the indirect effect is likely to be negative. Hence, the sign of the total welfare effect of nation A hinges on the sign and magnitude of the direct effect. We obtain the condition that inelastic offer curve for the nonparticipant (nonrecipient) nation is necessary for the direct effect to be negative (i.e. immiserization of A). This is similar to the condition discussed by BBH under free trade. We further show that immiserization is likely to occur when the recipient has a higher tax rate than the non-participant. Inferiority of the importable in the consumption of the donor is also identified as a condition for immiserization.

Next, we analyze the case of multilateral transfer. Three scenarios are considered. First, we consider equiproportionate multilateral transfer and show that transfers proportional to the exports of the recipient nations cannot immiserize either of the recipient nations provided the tax response of $\mathrm{B}$ is sufficiently small. This ensures that the negative indirect effect is small, and is outweighed by the positive direct and external effects combined together. This finding shows that the BBH (1983) result - that equiproportionate (transfers proportional to the exports) multilateral transfer under free trade cannot immiserize the recipients — can be extended to optimal taxation. Next, we consider equiproportionate multilateral transfer where the proportions are not equal to the exports of the recipient nations. We demonstrate that nation A is likely to be immiserized provided it receives a smaller share of the transfer and marginal propensity to consume good 1 by $\mathrm{C}\left(\right.$ i.e. $\left.\mathrm{g}_{1 \mathrm{M}}\right)>$ marginal propensity to consume good 1 by B (i.e.mpc $\mathrm{c}_{1 \mathrm{~B}}$ ). Finally, 
we show that when equal transfers are made to the exporting nation, then the nation with the higher optimal tax rate is likely to be immiserized. Here, the issue of asymmetry between exporting nations becomes crucial in analyzing the effects of transfer.

\subsection{The Model with Nash Welfare Maximizing Taxes}

Let us consider a general equilibrium model where there are three countries: A, B and C; and two goods: 1 and 2. Nations A and B not only export good 1 to nation $\mathrm{C}$ but also consume it domestically. $\mathrm{C}$ makes transfers $\mathrm{g}_{\mathrm{A}}$ and $\mathrm{g}_{\mathrm{B}}$ to $\mathrm{A}$ and $\mathrm{B}$, respectively. $\mathrm{C}$ consumes both goods but is specialized in producing good 2. A and B impose taxes $t_{A}$ and $t_{\mathrm{B}}$, respectively, while $\mathrm{C}$ follows free trade.

Let the expenditure functions of nation $A, B$ and $C$ be $E^{A}\left(p_{1}\left(1-t_{A}\right), 1, U^{A}\right)$, $E^{B}\left(p_{1}\left(1-t_{B}\right), 1, U^{B}\right)$ and $E^{C}\left(p_{1}, 1, U^{C}\right)$ respectively where $U^{A}, U^{B}$ and $U^{C}$ are the three nations utilities. Let good 2 be the numeraire good and the price of good 1 is denoted by $\mathrm{p}_{1}$. $\mathrm{R}^{\mathrm{A}}\left(\mathrm{p}_{1}\left(1-\mathrm{t}_{\mathrm{A}}\right), 1\right)$ and $\mathrm{R}^{\mathrm{B}}\left(\mathrm{p}_{1}\left(1-\mathrm{t}_{\mathrm{B}}\right), 1\right)$ are the respective revenue functions, $\mathrm{E}_{1}{ }^{\mathrm{A}}(),. \mathrm{E}_{1}{ }^{\mathrm{B}}($.$) and$ $\mathrm{E}_{1}{ }^{\mathrm{C}}\left(\mathrm{p}_{1}, 1, \mathrm{U}^{\mathrm{C}}\right)$ are the three countries' demand functions and $\mathrm{R}_{1}{ }^{\mathrm{A}}($.$) and \mathrm{R}_{1}{ }^{\mathrm{B}}($.$) are the$ respective supply functions. The following equations describe trade equilibrium in this general equilibrium framework.

$$
\begin{aligned}
& \mathrm{E}^{\mathrm{A}}\left(\mathrm{p}_{1}\left(1-\mathrm{t}_{\mathrm{A}}\right), 1, \mathrm{U}^{\mathrm{A}}\right)=\mathrm{R}^{\mathrm{A}}\left(\mathrm{p}_{1}\left(1-\mathrm{t}_{\mathrm{A}}\right), 1\right)+\mathrm{t}_{\mathrm{A}} \mathrm{p}_{1}\left(\mathrm{R}_{1}{ }^{\mathrm{A}}-\mathrm{E}_{1}{ }^{\mathrm{A}}\right)+\mathrm{g}_{\mathrm{A}} \\
& \mathrm{E}^{\mathrm{B}}\left(\mathrm{p}_{1}\left(1-\mathrm{t}_{\mathrm{B}}\right), 1, \mathrm{U}^{\mathrm{B}}\right)=\mathrm{R}^{\mathrm{B}}\left(\mathrm{p}_{1}\left(1-\mathrm{t}_{\mathrm{B}}\right), 1\right)+\mathrm{t}_{\mathrm{B}} \mathrm{p}_{1}\left(\mathrm{R}_{1}{ }^{\mathrm{B}}-\mathrm{E}_{1}{ }^{\mathrm{B}}\right)+\mathrm{g}_{\mathrm{B}} \\
& \mathrm{R}_{1}^{\mathrm{A}}(.)+\mathrm{R}_{1}^{\mathrm{B}}(.)=\mathrm{E}_{1}{ }^{\mathrm{A}}(.)+\mathrm{E}_{1}{ }^{\mathrm{B}}(.)+\mathrm{E}_{1}{ }^{\mathrm{C}}\left(\mathrm{p}_{1}, 1, \mathrm{U}^{\mathrm{C}}\right)
\end{aligned}
$$

The general equilibrium demand for good 1 by country $\mathrm{C}$ is defined as: 
$\varphi_{1}\left(p_{1}, 1, g_{A}, g_{B}\right)=E_{1}^{C}\left(p_{1}, 1, U^{C}\right)=g_{1}\left(p_{1}, 1, M\right)=g_{1}\left(p_{1}, 1, R^{C}\left(p_{1}, 1\right)-g_{A^{-}}-g_{B}\right)=g_{1}\left(p_{1}, 1, \bar{X}_{2}-g_{A^{-}} g_{B}\right)^{5}$

where $\mathrm{g}_{1}\left(\mathrm{p}_{1}, 1, \mathrm{M}\right)$ is the Marshallian demand for good 1 in nation $\mathrm{C}$ and $\mathrm{M}$ represents the national income of nation $C$. Since nation $C$ is completely specialized in good 2 , its national income M equals $\bar{X}_{2}-\mathrm{g}_{\mathrm{A}}-\mathrm{g}_{\mathrm{B}}$, where $\bar{X}_{2}$ is the maximum output of good 2 that $\mathrm{C}$ can produce, given its resources and technology. Equation (2.1) implicitly defines $\mathrm{U}^{\mathrm{A}}$ as a function of $\mathrm{p}_{1}, \mathrm{t}_{\mathrm{A}}, \mathrm{g}_{\mathrm{A}}$. Similarly equation (2.2) implicitly defines $\mathrm{U}^{\mathrm{B}}$ as a function of $\mathrm{p}_{1}, \mathrm{t}_{\mathrm{B}}, \mathrm{g}_{\mathrm{B}}$

$\mathrm{U}^{\mathrm{A}}=\mathrm{U}^{\mathrm{A}}\left(\mathrm{p}_{1}, \mathrm{t}_{\mathrm{A}}, \mathrm{g}_{\mathrm{A}}\right)$

$\mathrm{U}^{\mathrm{B}}=\mathrm{U}^{\mathrm{B}}\left(\mathrm{p}_{1}, \mathrm{t}_{\mathrm{B}}, \mathrm{g}_{\mathrm{B}}\right)$

Using the implicit functions (2.4) and (2.5) in (2.3) we have:

$\mathrm{R}_{1}{ }^{\mathrm{A}}\left(\mathrm{p}_{1}\left(1-\mathrm{t}_{\mathrm{A}}\right), 1\right)+\mathrm{R}_{1}{ }^{\mathrm{B}}\left(\mathrm{p}_{1}\left(1-\mathrm{t}_{\mathrm{B}}\right), 1\right)-\mathrm{E}_{1}{ }^{\mathrm{A}}\left(\mathrm{p}_{1}\left(1-\mathrm{t}_{\mathrm{A}}\right), 1, \mathrm{U}^{\mathrm{A}}\right)$

$-E_{1}^{B}\left(p_{1}\left(1-t_{B}\right), 1, U^{B}\right)-\varphi_{1}\left(p_{1}, 1, g_{A}, g_{B}\right)=0$

Equation (2.6) is the market clearing equation that implicitly defines $\mathrm{p}_{1}$ as a function of $t_{\mathrm{A}}, \mathrm{t}_{\mathrm{B}}, \mathrm{g}_{\mathrm{A}}, \mathrm{g}_{\mathrm{B}}$

$\mathrm{p}_{1}=\mathrm{p}_{1}\left(\mathrm{t}_{\mathrm{A}}, \mathrm{t}_{\mathrm{B}}, \mathrm{g}_{\mathrm{A}}, \mathrm{g}_{\mathrm{B}}\right)$

The tax policies of the two nations are obtained from the Nash optimal tax rules which maximize the welfare levels of each nation with respective to their tax rates given the tax rate of the other nation.

Differentiating (2.4) and using (2.6') we have the Nash optimal tax rule for nation A as:

$\partial \mathrm{U}^{\mathrm{A}} / \partial \mathrm{t}_{\mathrm{A}}=\mathrm{U}_{1}^{\mathrm{A}} \mathrm{p}_{11}+\mathrm{U}_{2}^{\mathrm{A}}=0$

\footnotetext{
${ }^{5}$ Note, $\varphi_{13}=\varphi_{14}=-g_{1 M}$ i.e. the effect of the transfer payment on the general equilibrium demand of nation $\mathrm{C}$ is the negative of nation C's income effect on its Marshallian demand function (i.e. nation C's marginal propensity to consume good 1)
} 
The tax rule for country B is:

$\partial \mathrm{U}^{\mathrm{B}} / \partial \mathrm{t}_{\mathrm{B}}=\mathrm{U}_{1}^{\mathrm{B}} \mathrm{p}_{12}+\mathrm{U}_{2}^{\mathrm{B}}=0$

(2.7) implies $t_{A}=t_{A}\left(g_{A}, g_{B}\right)$

(2.8) implies $t_{B}=t_{B}\left(g_{A}, g_{B}\right)$

Equations (2.1), (2.2), (2.6), (2.7) and (2.8) describe the general equilibrium system which solves for $\mathrm{U}^{\mathrm{A}}, \mathrm{U}^{\mathrm{B}}, \mathrm{t}_{\mathrm{A}}, \mathrm{t}_{\mathrm{B}}$ and $\mathrm{p}_{1}$.

\subsection{Some Useful Welfare and Price Effects}

Using equations (2.1) and (2.4) we can derive:

$\mathrm{U}_{1}^{\mathrm{A}}=\frac{R_{1}^{A}-E_{1}^{A}+t_{A} p_{1}\left(1-t_{A}\right)\left(R_{11}^{A}-E_{11}^{A}\right)}{E_{U}^{A}+t_{A} p_{1} E_{1 U}^{A}}$

The term $\mathrm{U}_{1}{ }^{\mathrm{A}}$ gives the effect of $\mathrm{p}_{1}$ on the welfare level of $\mathrm{A}$. To determine the sign of the expression we have to consider the numerator and the denominator separately. The denominator is positive under normality of good 1 . The numerator can be decomposed into two parts (a) $\mathrm{R}_{1}{ }^{\mathrm{A}}-\mathrm{E}_{1}{ }^{\mathrm{A}}$ denoting excess supply of good 1 , hence positive since nation $A$ is a net exporter of good 1 (b) $t_{A} p_{1}\left(1-t_{A}\right)\left(R_{11}{ }^{A}-E_{11}{ }^{A}\right)$. Now, the slope of the excess supply function given by $\mathrm{R}_{11}{ }^{\mathrm{A}}-\mathrm{E}_{11}{ }^{\mathrm{A}}$ is positive from the convexity of the $\mathrm{R}($.$) and the$ concavity of the $\mathrm{E}($.$) functions. Hence, the effect of \mathrm{p}_{1}$ on the welfare of nation $\mathrm{A}$ is positive. The intuition is that good 1 being the export good for nation A, the increase (decrease) in its price raises (reduces) the welfare level of nation A. Similarly,

$\mathrm{U}_{2}^{\mathrm{A}}=\frac{t_{A} p_{1}^{2}\left(E_{11}^{A}-R_{11}^{A}\right)}{E_{U}^{A}+t_{A} p_{1} E_{1 U}^{A}}<0$ 
$\mathrm{U}_{3}{ }^{\mathrm{A}}=\frac{1}{E_{U}^{A}+t_{A} p_{1} E_{1 U}^{A}}>0$

Equation (2.4b) suggests that an increase in its own tax rate leads to a reduction in the welfare level, because of the production and consumption distortion. Equation (2.4c) captures the direct income effect on A due to the receipt of $g_{A}$, which raises its welfare.

Compiling (2.4a), (2.4b) and (2.4c), we have

$\mathrm{U}_{1}^{\mathrm{A}}=\left[\operatorname{Exp}_{1}{ }^{\mathrm{A}}+\mathrm{t}_{\mathrm{A}} \mathrm{p}_{1}\left(1-\mathrm{t}_{\mathrm{A}}\right)\left(\mathrm{R}_{11}{ }^{\mathrm{A}}-\mathrm{E}_{11}{ }^{\mathrm{A}}\right)\right] \mathrm{U}_{3}{ }^{\mathrm{A}}$

$\mathrm{U}_{2}^{\mathrm{A}}=\mathrm{t}_{\mathrm{A}} \mathrm{p}_{1}^{2}\left(\mathrm{R}_{11}{ }^{\mathrm{A}}-\mathrm{E}_{11}{ }^{\mathrm{A}}\right) \mathrm{U}_{3}^{\mathrm{A}}$

The effects of nation A's tax rate, nation B's tax rate, nation A's transfer payment and nation B's transfer payment on the price level are given by $\mathrm{p}_{11}, \mathrm{p}_{12}, \mathrm{p}_{13}$ and $\mathrm{p}_{14}$ respectively. The expressions can be derived from (2.6) as:

$\mathrm{p}_{11}=\frac{p_{1}\left(R_{11}^{A}-E_{11}^{A}\right) E_{U}^{A}}{E_{U}^{A}+t_{A} p_{1} E_{1 U}^{A}} \cdot \frac{1}{M L C}$

$\mathrm{p}_{12}=\frac{p_{1}\left(R_{11}^{B}-E_{11}^{B}\right) E_{U}^{B}}{E_{U}^{B}+t_{B} p_{1} E_{1 U}^{B}} \cdot \frac{1}{M L C}$

$\mathrm{p}_{13}=\frac{E_{1 U}^{A} U_{3}^{A}+\phi_{13}}{M L C}=\frac{E_{1 U}^{A} U_{3}^{A}-g_{1 M}}{M L C}$

$\mathrm{p}_{14}=\frac{E_{1 U}^{B} U_{3}^{B}+\phi_{14}}{M L C}=\frac{E_{1 U}^{B} U_{3}^{B}-g_{1 M}}{M L C}$

where MLC is the slope of the global excess supply function.

$M L C=R_{11}{ }^{A}\left(1-t_{A}\right)+R_{11}{ }^{B}\left(1-t_{B}\right)-E_{11}{ }^{A}\left(1-t_{A}\right)-E_{1 U}{ }^{A} U_{1}^{A}-E_{11}{ }^{B}\left(1-t_{B}\right)-E_{1 U}{ }^{B} U_{1}^{B}-\varphi_{11}>0$ from Marshall Lerner condition for stability of international equilibrium. 


\subsection{The Case of Bilateral Transfers}

Set $\operatorname{dg}_{\mathrm{B}}=0$

Differentiating (2.4) and using (2.6') and (2.7), we have the welfare effect for nation A:

$\mathrm{dU}^{\mathrm{A}}=\mathrm{U}_{1}{ }^{\mathrm{A}} \mathrm{p}_{12} \mathrm{dt}_{\mathrm{B}}+\left(\mathrm{U}_{1}{ }^{\mathrm{A}} \mathrm{p}_{13} \mathrm{dg}_{\mathrm{A}}+\mathrm{U}_{3}{ }^{\mathrm{A}}\right) \mathrm{dg}_{\mathrm{A}}$

Note: Here the first term on the right-hand side denotes the indirect effect and combining the second and the third term we have the direct effect.

$\mathrm{dU}^{\mathrm{A}} / \mathrm{dg}_{\mathrm{A}}=\mathrm{U}_{1}{ }^{\mathrm{A}} \mathrm{p}_{12} \mathrm{dt}_{\mathrm{B}} / \mathrm{dg}_{\mathrm{A}}+\left(\mathrm{U}_{1}{ }^{\mathrm{A}} \mathrm{p}_{13}+\mathrm{U}_{3}{ }^{\mathrm{A}}\right)$

As mentioned before, $\mathrm{dt}_{\mathrm{B}} / \mathrm{dg}_{\mathrm{A}}<0$

The optimal tax rule of A can be rewritten as:

$\mathrm{U}_{1}^{\mathrm{A}}=\mathrm{t}_{\mathrm{A}} \mathrm{p}_{1} \mathrm{MLC} / \mathrm{E}_{\mathrm{U}}^{\mathrm{A}}$

Using (2.6b) and (2.10) we have:

$\mathrm{U}_{1}^{\mathrm{A}} \mathrm{p}_{12}=\frac{t_{A} p_{1}^{2}\left(R_{11}^{B}-E_{11}^{B}\right) E_{U}^{B}}{\left(E_{U}^{B}+t_{B} p_{1} E_{1 U}^{B}\right) E_{U}^{A}}>0$

$\Rightarrow \mathrm{U}_{1}{ }^{\mathrm{A}} \mathrm{p}_{12} \mathrm{dt}_{\mathrm{B}} / \mathrm{dg}_{\mathrm{A}}<0$

Therefore, $\mathrm{dU}^{\mathrm{A}} / \mathrm{dg}_{\mathrm{A}}$ is likely to be negative if $\mathrm{U}_{1}{ }^{\mathrm{A}} \mathrm{p}_{13}+\mathrm{U}_{3}{ }^{\mathrm{A}}<0$.

Using (2.10) and (2.6c) we have:

$\mathrm{U}_{1}{ }^{\mathrm{A}} \mathrm{p}_{13}+\mathrm{U}_{3}^{\mathrm{A}}=\frac{1-t_{A} p_{1} g_{1 M}}{E_{U}^{A}}$

Thus immiserization might occur if $1-\mathrm{t}_{\mathrm{A}} \mathrm{p}_{1} \mathrm{~g}_{1 \mathrm{M}}<0$

The optimal tax rule of $\mathrm{A}$ in (2.7) can be rewritten as:

$\operatorname{Exp}_{1}{ }^{\mathrm{A}}=\mathrm{t}_{\mathrm{A}} \mathrm{p}_{1}\left[\mathcal{E}_{1}^{B}-\mathrm{E}_{11}{ }^{\mathrm{C}}+\mathrm{g}_{1} \mathrm{~g}_{1 \mathrm{M}}\right]$ 
where, $\operatorname{Exp}_{1}{ }^{\mathrm{A}}=$ exports of $\mathrm{A}$ and $\left.\mathcal{E}_{1}^{B}=\left(1-\mathrm{t}_{\mathrm{B}}\right)\right)\left(\mathrm{R}_{11}{ }^{\mathrm{B}}-\mathrm{E}_{11}{ }^{\mathrm{B}}\right)-\mathrm{E}_{1 \mathrm{U}}{ }^{\mathrm{B}} \mathrm{U}_{1}{ }^{\mathrm{B}}$ is the slope of the excess export supply for nation B.

Similarly, the optimal tax rule of B:

$\operatorname{Exp}_{1}{ }^{\mathrm{B}}=\mathrm{t}_{\mathrm{B}} \mathrm{p}_{1}\left[\mathcal{E}_{1}^{A}-\mathrm{E}_{11}{ }^{\mathrm{C}}+\mathrm{g}_{1} \mathrm{~g}_{1 \mathrm{M}}\right]$

where, $\operatorname{Exp}_{1}{ }^{\mathrm{B}}=$ exports of $\mathrm{B}$ and $\varepsilon_{1}^{A}$ is the slope of the excess export supply for nation $\mathrm{A}$.

Consider, $\operatorname{Exp}_{1}{ }^{\mathrm{A}}+\operatorname{Exp}_{1}{ }^{\mathrm{B}}=\mathrm{g}_{1}=\mathrm{t}_{\mathrm{A}} \mathrm{p}_{1} \mathrm{~g}_{1} \mathrm{~g}_{1 \mathrm{M}}+\mathrm{t}_{\mathrm{A}} \mathrm{p}_{1}\left[\mathcal{E}_{1}^{B}-\mathrm{E}_{11}{ }^{\mathrm{C}}\right]+\mathrm{t}_{\mathrm{B}} \mathrm{p}_{1}\left[\mathcal{E}_{1}^{A}-\mathrm{E}_{11}{ }^{\mathrm{C}}+\mathrm{g}_{1} \mathrm{~g}_{1 \mathrm{M}}\right]$

Hence, $\mathrm{g}_{1}\left[1-\mathrm{t}_{\mathrm{A}} \mathrm{p}_{1} \mathrm{~g}_{1 \mathrm{M}}\right]=\mathrm{t}_{\mathrm{A}} \mathrm{p}_{1}\left[\mathcal{E}_{1}^{B}-\mathrm{E}_{11}{ }^{\mathrm{C}}\right]+\mathrm{t}_{\mathrm{B}} \mathrm{p}_{1}\left[\mathcal{E}_{1}^{A}-\mathrm{E}_{11}{ }^{\mathrm{C}}+\mathrm{g}_{1} \mathrm{~g}_{1 \mathrm{M}}\right]$

$=\mathrm{t}_{\mathrm{A}} \mathrm{p}_{1}\left[\mathcal{E}_{1}^{B}-\mathrm{E}_{11}{ }^{\mathrm{C}}\right]+\mathrm{t}_{\mathrm{B}} \mathrm{p}_{1} \operatorname{Exp}_{1}{ }^{\mathrm{B}}$

We know $\operatorname{Exp}_{1}{ }^{\mathrm{B}}>0$ and $\mathrm{E}_{11}{ }^{\mathrm{C}}<0$. Therefore, the negativity of $\mathcal{E}_{1}^{B}$ is a necessary condition for the occurrence of immiserization.

Equation (2.15) can be rewritten as:

$\mathrm{g}_{1}\left[1-\mathrm{t}_{\mathrm{A}} \mathrm{p}_{1} \mathrm{~g}_{1 \mathrm{M}}\right]=\mathrm{p}_{1} \varepsilon_{1}^{B}\left[\mathrm{t}_{\mathrm{A}}-\mathrm{t}_{\mathrm{B}}\right]-\mathrm{t}_{\mathrm{A}} \mathrm{p}_{1} \mathrm{E}_{11}{ }^{\mathrm{C}}+\mathrm{t}_{\mathrm{B}} \mathrm{p}_{1} \mathrm{MLC}$

where MLC $=\varepsilon_{1}^{A}+\varepsilon_{1}^{B}-\mathrm{E}_{11}^{\mathrm{C}}+\mathrm{g}_{1} \mathrm{~g}_{1 \mathrm{M}}$

Consider, $\varepsilon_{1}^{B}<0$

Case 1: $\quad t_{\mathrm{A}} \leq \mathrm{t}_{\mathrm{B}}$

$\left[1-t_{A} p_{1} g_{1 M}\right]>0$ since $E_{11}{ }^{C}<0$ and MLC $>0$. Therefore, immiserization is not possible.

Case 2: $\quad t_{\mathrm{A}}>\mathrm{t}_{\mathrm{B}}$

In this case the first term on the right hand side of the final expression is negative and the remaining terms are positive. Therefore, we cannot rule out immiserization of $\mathrm{A}$ if it is the nation with a higher tax. 
Note: Here immiserization occurs when $1-t_{A} p_{1} g_{1 M}<0$. This implies $t_{A} p_{1} g_{1 M}>1$ i.e.

$\mathrm{p}_{1} \mathrm{~g}_{1 \mathrm{M}}>1$ since $0<\mathrm{t}_{\mathrm{A}}<1$.

We know from Engel's law, $\mathrm{p}_{1} \mathrm{~g}_{1}\left(\mathrm{p}_{1}, 1, \mathrm{M}\right)+\mathrm{g}_{2}\left(\mathrm{p}_{1}, 1, \mathrm{M}\right)=\mathrm{M}$

Therefore, $\mathrm{p}_{1} \mathrm{~g}_{1 \mathrm{M}}+\mathrm{g}_{2 \mathrm{M}}=1$

$\mathrm{p}_{1} \mathrm{~g}_{1 \mathrm{M}}>1$ iff $\mathrm{g}_{2 \mathrm{M}}<0$ i.e. inferiority of good 2 is necessary for the outcome of transfer immiserization for nation A.

\section{$\underline{\text { PROPOSITION } 1}$}

Necessary conditions for recipient immiserization are that the non-participant nation's offer curve is backward bending and good 2 is inferior in consumption for nation C. Immiserization cannot be ruled out if the recipient's tax rate exceeds that of the nonparticipant.

\section{$\underline{\text { Proof and Comment }}$}

The proof follows from the above discussion. Backward bending supply curve implies that the supply of export good rises as relative price falls. Hence due to transfer as soon as the price of good 1 falls, nation B increases the supply due to its backward bending offer curve, which reinforces the price fall and results in immiserization. However, a high tax rate of $\mathrm{B}$ arrests this perverse price response and rules out immiserization.

When good 2 is inferior in consumption for nation C, good 1 shows large income effects. This results in a large terms of trade deterioration for nation $\mathrm{A}$ and $\mathrm{B}$ while nation $\mathrm{C}$ loses 
income in the transfer process. Nation B enjoys a free ride on the high tax rates imposed by nation $\mathrm{A}$ and is able to retain most of its gain, whereas nation A suffers a welfare loss.

\subsection{The Case of Multilateral Transfers}

In this case the welfare effect for nation $\mathrm{A}$ is given as:

$\mathrm{dU}^{\mathrm{A}}=\mathrm{U}_{1}^{\mathrm{A}} \mathrm{p}_{12} \mathrm{dt}_{\mathrm{B}}+\left(\mathrm{U}_{1}^{\mathrm{A}} \mathrm{p}_{13}+\mathrm{U}_{3}^{\mathrm{A}}\right) \mathrm{dg}_{\mathrm{A}}+\mathrm{U}_{1}^{\mathrm{A}} \mathrm{p}_{14} \mathrm{dg}_{\mathrm{B}}$

Note: Here we have the external effect of transfer (i.e. $\mathrm{U}_{1}{ }^{\mathrm{A}} \mathrm{p}_{14} \mathrm{dg} \mathrm{g}_{\mathrm{B}}$ ) which is the effect of transfer to B on A's welfare.

Using (2.12) we can rewrite (2.17) as:

$\mathrm{dU}^{\mathrm{A}}=\frac{1-t_{A} p_{1} g_{1 M}}{E_{U}^{A}} \mathrm{dg}_{\mathrm{A}}+\mathrm{U}_{1}{ }^{\mathrm{A}} \mathrm{p}_{12} \mathrm{dt}_{\mathrm{B}}+\mathrm{U}_{1}{ }^{\mathrm{A}} \mathrm{p}_{14} \mathrm{dg}_{\mathrm{B}}$

Let dg be the total transfer made by $\mathrm{C}$ to $\mathrm{A}$ and $\mathrm{B}$. Let $\alpha$ be the fraction going to $\mathrm{A}$. Consider transfers to be proportional to the exports of the two nations then the paradox can be ruled when nation B's tax response is sufficiently small.

Hence, $\operatorname{dg}_{\mathrm{A}}=\frac{\operatorname{Exp}_{1}^{A}}{\operatorname{Exp}_{1}^{A}+\operatorname{Exp}_{1}^{B}} \mathrm{dg}=\frac{\operatorname{Exp}_{1}^{A}}{g_{1}} \mathrm{dg} ; \mathrm{dg}_{\mathrm{B}}=\frac{\operatorname{Exp}_{1}^{B}}{g_{1}} \mathrm{dg}$ and assume $\mathrm{dt}_{\mathrm{B}} / \mathrm{dg}$ is sufficiently small.

Hence (2.18) reduces to:

$\mathrm{dU}^{\mathrm{A}} / \mathrm{dg}=\frac{t_{A} p_{1}}{E_{U}^{A} g_{1}}\left[\frac{\left(1-t_{B}\right)\left(R_{11}^{B}-E_{11}^{B}\right) E_{U}^{B}}{E_{U}^{B}+t_{B} p_{1} E_{1 U}^{B}}-\mathrm{E}_{11}{ }^{\mathrm{C}}\right]+\mathrm{U}_{1}{ }^{\mathrm{A}} \mathrm{p}_{12} \mathrm{dt}_{\mathrm{B}} / \mathrm{dg}>0$

since, $\mathrm{U}_{1}^{\mathrm{A}} \mathrm{p}_{12}>0$ 


\section{PROPOSITION 2}

Multilateral transfers made in proportion to the exports of the two exporting nations must raise A's welfare, provided nation B has a sufficiently small tax response.

\section{PROOF AND COMMENT}

(2.19) provides the proof. We have run extensive simulations and in all of them the tax response $\left(\mathrm{dt}_{\mathrm{B}}\right)$ is sufficiently small. The only possible losses in this scenario are caused by the adverse externality created by the other nation due to its receipts of transfer payment and, as we have shown above, when transfers are proportional to the exports of the recipient nations, this externality is not strong enough to outweigh the primary gains from transfers. This finding extends the $\mathrm{BBH}$ result that equiproportionate transfers cannot immiserize under free trade to the case of export taxation.

Now consider equiproportionate transfers that are not proportional to the exports of the recipient nations.

Hence, $\operatorname{dg}_{\mathrm{A}}=\alpha \mathrm{dg}$ and $\mathrm{dg}_{\mathrm{B}}=(1-\alpha) \mathrm{dg}$

Simplifying (2.17) we get:

$\mathrm{dU}^{\mathrm{A}} / \mathrm{dg}=\frac{1-t_{A} p_{1} g_{1 M}}{E_{U}^{A}} \alpha+\mathrm{U}_{1}{ }^{\mathrm{A}} \mathrm{p}_{14}(1-\alpha)+\mathrm{U}_{1}{ }^{\mathrm{A}} \mathrm{p}_{12} \mathrm{dt}_{\mathrm{B}} / \mathrm{dg}$

According to our argument made before $\mathrm{U}_{1}{ }^{\mathrm{A}} \mathrm{p}_{12} \mathrm{dt} \mathrm{t}_{\mathrm{B}} / \mathrm{dg}$ is likely to be negative. Clearly, if $\alpha$ is small, then a multilateral transfer is likely to immiserize nation $\mathrm{A}$ if $\mathrm{p}_{14}$ is negative i.e. $\mathrm{p}_{1}$ falls due to the receipt of transfer by $\mathrm{B}$. This happens when B's marginal 
propensity to consume good $1\left(\mathrm{mpc}_{1 \mathrm{~B}}\right)$ is less than that of $\mathrm{C}\left(\mathrm{g}_{1 \mathrm{M}}\right)$. The intuition is provided in the proof and comment of this proposition.

\section{$\underline{\text { PROPOSITION } 3}$}

Multilateral transfers which are not proportional to the exports of the recipient nations are likely to reduce the welfare of nation A, provided A receives a smaller share of the total transfer and $\mathrm{g}_{1 \mathrm{M}}>\mathrm{mpc} \mathrm{c}_{1 \mathrm{~B}}$.

\section{PROOF AND COMMENT}

When $\mathrm{C}$ makes transfer to $\mathrm{B}$, it ends up with lower income. Hence, $\mathrm{C}$ demands less of good 1. However, good 1 is also consumed by nation B, which has a higher income due to the receipts of transfer. It is obvious if nation C's marginal propensity to consume $\left(\mathrm{g}_{1 \mathrm{M}}\right)$ is greater than that of $\mathrm{B}\left(\mathrm{mpc}_{1 \mathrm{~B}}\right)$ then post transfer net demand for good 1 falls, hence the price of good 1 itself falls. Nation A being the exporter of good 1 gets hurt in this process. The assumption $\mathrm{g}_{1 \mathrm{M}}>\mathrm{mpc}_{1 \mathrm{~B}}$ is consistent with the real world situation of cocoa where domestic consumption in the exporting nation is not so significant.

Now consider equal transfer where $\mathrm{dg}_{\mathrm{A}}=\mathrm{dg}_{\mathrm{B}}=\mathrm{dg}$ and (2.17) becomes:

$d U^{A} / d g=U_{1}^{A} p_{13}+U_{1}^{A} p_{14}+U_{3}{ }^{A}+U_{1}^{A} p_{12} d_{B} / d g$

Using (2.12) we can rewrite (2.21) as:

$\mathrm{dU}^{\mathrm{A}} / \mathrm{dg}=\frac{1-t_{A} p_{1} g_{1 M}}{E_{U}^{A}}+\mathrm{U}_{1}^{\mathrm{A}} \mathrm{p}_{14}+\mathrm{U}_{1}^{\mathrm{A}} \mathrm{p}_{12} \mathrm{dt}_{\mathrm{B}} / \mathrm{dg}$ 
It can be shown that $\frac{1-t_{A} p_{1} g_{1 M}}{E_{U}^{A}}+\mathrm{U}_{1}{ }^{\mathrm{A}} \mathrm{p}_{14}$

$=\frac{t_{A} p_{1}}{g_{1} E_{U}^{A}}\left[\mathrm{U}_{3}{ }^{\mathrm{B}} E_{1 U}^{B} \operatorname{Exp}_{1}^{A}-E_{11}^{C}+\left(1-\mathrm{t}_{\mathrm{B}}\right)\left(R_{11}^{B}-E_{11}^{B}\right) E_{U}^{B} \mathrm{U}_{3}{ }^{\mathrm{B}}+\frac{t_{B}}{t_{A}}\left(\varepsilon_{1}^{A}-E_{11}^{C}\right)+\left(\frac{t_{B}}{t_{A}}-1\right) \mathrm{g}_{1} \mathrm{~g}_{1 \mathrm{M}}\right]>0$

provided $\varepsilon_{1}^{A}>0$ and $\mathrm{t}_{\mathrm{B}}>\mathrm{t}_{\mathrm{A}}$ where $\mathrm{U}_{3}{ }^{\mathrm{B}}=\frac{1}{E_{U}^{B}+t_{B} p_{1} E_{1 U}^{B}}$

Notice that: $\varepsilon_{1}^{A}=\left(1-\mathrm{t}_{\mathrm{A}}\right)\left(R_{11}^{A}-E_{11}^{A}\right)-E_{1 U}^{A} \mathrm{U}_{1}^{\mathrm{A}}$. In the absence of consumption of good-1 in the exporting nations as assumed in Panagariya-Schiff (1991 and 1995), $E_{1 U}^{A}=0$, and $\varepsilon_{1}^{A}$

is strictly positive. As long as $E_{1 U}^{A}$ is small, $\varepsilon_{1}^{A}$ (i.e., the slope of the export supply curve of A) is likely to be positive. This implies that for a sufficiently small tax response of nation $\mathrm{B}$,

$\mathrm{dU}^{\mathrm{A}} / \mathrm{dg}=\frac{1-t_{A} p_{1} g_{1 M}}{E_{U}^{A}}+\mathrm{U}_{1}{ }^{\mathrm{A}} \mathrm{p}_{14}+\mathrm{U}_{1}{ }^{\mathrm{A}} \mathrm{p}_{12} \mathrm{dt}_{\mathrm{B}} / \mathrm{dg}>0$

\section{$\underline{\text { PROPOSITION } 4}$}

When an equal multilateral transfer is made to the two exporting nations then for a sufficiently small tax response of nation $B$, nation $A$ cannot be immiserized provided $t_{B}>$ $t_{A}$. On the other hand if $t_{A}>t_{B}$, then $A$ can be immiserized.

\section{PROOF AND COMMENT}

We have provided simulation examples that establish nation A may be immiserized if $t_{\mathrm{A}}>t_{\mathrm{B}}$. Note that a larger exporter is likely to have a higher export tax because it faces a 
less elastic residual demand curve. Thus proposition 4 suggests that the larger exporter is more vulnerable to immiserization through multilateral transfers. This is related to Bandyopadhyay's (1996) finding that larger exporting nations with higher Nash welfare maximizing export taxes are more vulnerable to immiserizing growth. The reason behind these findings derives from the public good property of the export tax imposed by a nation. The smaller exporting nations free rides on the high export tax imposed by the larger exporter and, thereby, do not adequately restrict exports (from the point of view of the larger exporter). Thus, adverse terms of trade movements can be significant enough in a multicountry context to lead to immiserization of the larger exporter.

\subsection{Conclusion}

The issue of transfers has been extensively analyzed in international trade theory. However, there has been very little work dealing with the connections between export taxation, welfare effects of transfers, and asymmetry between the recipients. This essay discusses some of these important issues. The analysis shows the importance of asymmetry in analyzing interdependence in a multi country framework. Being more aggressive in taxation is a disadvantage in terms of gaining from the receipts of transfer. The larger exporter exercises more market power and is also more vulnerable to the adverse welfare effects of transfer. Welfare effects of transfer are analyzed in both bilateral and multilateral scenarios. In the bilateral case, the necessary conditions for immiserization are very stringent. Thus, in reality, immiserization is unlikely to happen. 
However, this is not true in the multilateral case, where the simulation results strongly support the possibility of immiserization through equal and proportionate transfers. 


\subsection{Simulation Results Supporting Multilateral Transfer}

In this section, simulation examples are presented supporting propositions 2,3 and 4 . We have run extensive simulations using GAMS to establish the propositions discussed in the multilateral transfer. For a better understanding, we present the simulation results in a tabular form for proposition 4. We start with the functional forms of the revenue, expenditure and utility functions.

\section{THE RELEVANT FUNCTIONAL FORMS}

\section{(a) $\quad \underline{\text { Revenue Function }}$}

We assume Cobb-Douglas production functions for the two goods in order to derive the revenue functions.

Let the production functions for good 1 and 2 be:

$$
\mathrm{X}_{1}=\mathrm{L}^{\mathrm{a}} \mathrm{K}^{1-\mathrm{a}} \text { and } \mathrm{X}_{2}=\mathrm{L}^{\mathrm{b}} \mathrm{K}^{1-\mathrm{b}}
$$

Therefore, the revenue function of nation $\mathrm{i}$ is:

$$
\mathrm{R}^{\mathrm{i}}\left(\mathrm{p}_{1}, \mathrm{p}_{2} ; \mathrm{N}, \mathrm{K}\right)=\mathrm{N} \mathrm{B}_{1}{ }^{\mathrm{s} 1} \mathrm{~B}_{2}{ }^{\mathrm{s} 2} \mathrm{p}_{1}{ }^{-\mathrm{s} 1} \mathrm{p}_{2}{ }^{-\mathrm{s} 2}+\mathrm{K} \mathrm{B}_{1}{ }^{\mathrm{s} 3} \mathrm{~B}_{2}{ }^{\mathrm{s} 4} \mathrm{p}_{1}{ }^{-\mathrm{s} 3} \mathrm{p}_{2}{ }^{-\mathrm{s} 4}
$$

where $s 1=(b-1) /(a-b) ; s 2=(1-a) /(a-b) ; s 3=b /(a-b) ; s 4=-a /(a-b)$

Hence the revenue function for nation $\mathrm{A}$ is:

$$
\mathrm{R}^{\mathrm{A}}\left(\mathrm{p}_{1}\left(1-\mathrm{t}_{\mathrm{A}}\right), 1\right)=\mathrm{N}_{\mathrm{A}} \mathrm{B}_{1}{ }^{\mathrm{s} 1} \mathrm{~B}_{2}{ }^{\mathrm{s} 2} \mathrm{p}_{1 \mathrm{~A}}{ }^{-\mathrm{s} 1}+\mathrm{K}_{\mathrm{A}} \mathrm{B}_{1}{ }^{\mathrm{s} 3} \mathrm{~B}_{2}{ }^{\mathrm{s} 4} \mathrm{p}_{1 \mathrm{~A}}{ }^{-\mathrm{s} 3} \text {, where } \mathrm{p}_{1 \mathrm{~A}}=\mathrm{p}_{1}\left(1-\mathrm{t}_{\mathrm{A}}\right)
$$

Revenue function for nation $B$ is:

$$
\mathrm{R}^{\mathrm{B}}\left(\mathrm{p}_{1}\left(1-\mathrm{t}_{\mathrm{B}}\right), 1\right)=\mathrm{N}_{\mathrm{B}} \mathrm{B}_{1}{ }^{\mathrm{s} 1} \mathrm{~B}_{2}{ }^{\mathrm{s} 2} \mathrm{p}_{1 \mathrm{~A}}{ }^{\mathrm{s} 1}+\mathrm{K}_{\mathrm{B}} \mathrm{B}_{1}{ }^{\mathrm{s} 3} \mathrm{~B}_{2}{ }^{\mathrm{s} 4} \mathrm{p}_{1 \mathrm{~A}}{ }^{-\mathrm{s} 3} \text {, where } \mathrm{p}_{1 \mathrm{~B}}=\mathrm{p}_{1}\left(1-\mathrm{t}_{\mathrm{B}}\right)
$$

(b) Expenditure Function 
The utility functions assumed here are also Cobb-Douglas, which lead to our specific expenditure functions.

$$
\mathrm{U}=\mathrm{C}_{1}{ }^{\alpha} \mathrm{C}_{2}{ }^{1-\alpha}
$$

Hence, the expenditure function is:

$E\left(p_{1}, p_{2}, U\right)=p_{1} C_{1}+p_{2} C_{2}=(1-\alpha)^{\alpha-1} \alpha^{-\alpha} p_{1}^{\alpha} p_{2}^{1-\alpha} U$

The expenditure function for nation $\mathrm{A}$ is:

$$
\mathrm{E}^{\mathrm{A}}\left(\mathrm{p}_{1}\left(1-\mathrm{t}_{\mathrm{A}}\right), 1, \mathrm{U}^{\mathrm{A}}\right)=(1-\alpha)^{\alpha-1} \alpha^{-\alpha}\left[\mathrm{p}_{1}\left(1-\mathrm{t}_{\mathrm{A}}\right)\right]^{\alpha} \mathrm{U}^{\mathrm{A}}
$$

Similarly, the expenditure function for nation B is:

$$
E^{B}\left(p_{1}\left(1-t_{B}\right), 1, U^{B}\right)=(1-\alpha)^{\alpha-1} \alpha^{-\alpha}\left[p_{1}\left(1-t_{B}\right)\right]^{\alpha} U^{B}
$$

\section{(c) Demand function for good 1 by nation $\mathrm{C}$}

The utility function for nation $\mathrm{C}$ postulated here is an addilog utility function that generates strong income effects. This helps the occurrence of immiserization.

Let the indirect utility function of the donor nation be an addilog function of the form:

$$
\mathrm{v}\left(\mathrm{p}_{1}, \mathrm{p}_{2}, \mathrm{y}\right)=\left(\mathrm{y} / \mathrm{p}_{1}\right)^{\mathrm{z} 1}+\left(\mathrm{y} / \mathrm{p}_{2}\right)^{\mathrm{z2}}
$$

Hence the Marshallian demand function for good 1 is of the form:

$$
\mathrm{g}_{1}\left(\mathrm{p}_{1}, \mathrm{p}_{2}, \mathrm{y}\right)=\mathrm{y}^{\mathrm{z1}} \mathrm{p}_{1}{ }^{-(1+\mathrm{z} 1)} \mathrm{z} 1 /\left(\left(\mathrm{y}^{\mathrm{z} 1-1} \mathrm{p}_{1}{ }^{-\mathrm{z} 1} \mathrm{z} 1+\mathrm{y}^{\mathrm{z2}-1} \mathrm{p}_{1}{ }^{-\mathrm{z} 2} \mathrm{z} 2\right)\right.
$$

The income for the donor nation is $\mathrm{y}=\mathrm{p}_{2} \mathrm{X}_{2}{ }^{*}$ where $\mathrm{X}_{2}{ }^{*}=\left(\mathrm{N}^{*}\right)^{\mathrm{b}}\left(\mathrm{K}^{*}\right)^{1-\mathrm{b}}$

where $\mathrm{N}^{*}$ and $\mathrm{K}^{*}$ are the labor and capital endowments of the donor nation. Since good 2 is the numeraire commodity, the price of good 2 is unity. Hence the general equilibrium demand function for good 1 by nation $\mathrm{C}$ is:

$$
\varphi_{1}\left(p_{1}, 1\right)=y^{z 1} p_{1}^{-(1+z 1)} z 1 /\left(\left(y^{z 1-1} p_{1}^{-z 1} z 1+y^{z 2-1} z 2\right)\right.
$$

The parameter configurations used in all the examples are: 
$\alpha=0.1, \mathrm{a}=0.7, \mathrm{~b}=0.2, \mathrm{z} 1=2.0, \mathrm{z} 2=1.0, \mathrm{~s} 1=-1.6, \mathrm{~s} 2=0.6, \mathrm{~s} 3=0.4, \mathrm{~s} 4=-1.4$ and $\mathrm{y}=2000$.

\section{PROPOSITION 2: SIMULATION EXAMPLE}

In this example, equiproportionate (proportional to the exports) transfers are made to nations $\mathrm{A}$ and $\mathrm{B}$ in the amounts of 0.702 and 0.298 . The labor endowments of $\mathrm{A}$ and $\mathrm{B}$ are 9000 and 1000, respectively, and the capital endowments of the two nations are 5000 and 800. The optimal Nash tax rates of nation A and B are 0.48683746 and 0.06000518 , respectively, in the pre-transfer case. The welfare level of nation A is 4974.269. When nation $\mathrm{C}$ makes an equiproportionate transfer to both the nations, the welfare level of nation $\mathrm{A}$ rises to 4974.439 and the tax rate of nation $\mathrm{B}$ falls to 0.05998841 . The fall of the tax rate of nation $\mathrm{B}$ is 0.00001677 , which can be considered as a very small tax response by nation $B$. If we consider equation (17) in our paper, the first term on the right

hand side, $U_{1}^{A} p_{12} d t_{B}$ captures the tax response of nation B that explains only $3.69 \%$ of the welfare increase. Thus, the tax response of nation B, even though negative, has a very small effect in the total welfare effect of nation A, leading to an increase in its welfare. This supports proposition 2 .

\section{PROPOSITION 3: SIMULATION RESULTS}

In this example proportional (not proportional to the exports) transfers are made to nations $\mathrm{A}$ and $\mathrm{B}$ in the amounts of 0.2 and 0.8 . Note here that $\mathrm{A}$ receives a smaller share of transfer than B. The labor endowments of A and B are 9000 and 1000, respectively, and the capital endowments of the two nations are 5000 and 800 . The welfare level of 
nation $\mathrm{A}$ in the pre-transfer case is 4974.269. In the post-transfer case the welfare of $\mathrm{A}$ falls to 4974.074. Also notice $\mathrm{g}_{1 \mathrm{M}}=0.9033>\mathrm{mpc}_{1 \mathrm{~B}}=0.0961$. This supports proposition 3 .

\section{PROPOSITION 4: SIMULATION RESULTS}

\begin{tabular}{|c|c|c|r|r|r|r|r|r|r|r|}
\hline $\mathrm{N}_{\mathrm{A}}$ & $\mathrm{U}^{\mathrm{A}}(0)$ & $\mathrm{U}^{\mathrm{A}}(1)$ & $\mathrm{dU}^{\mathrm{A}}$ & $\mathrm{U}^{\mathrm{B}}(0)$ & $\mathrm{U}^{\mathrm{B}}(1)$ & $\mathrm{dU}^{\mathrm{B}}$ & $\mathrm{t}_{\mathrm{A}}{ }^{0}$ & $\mathrm{t}_{\mathrm{B}}{ }^{0}$ & $\mathrm{t}_{\mathrm{A}}{ }^{0} / \mathrm{t}_{\mathrm{B}}{ }^{0}$ & $\mathrm{Exp}_{1}{ }^{\mathrm{A}} / \mathrm{g}_{1}$ \\
\hline 5220 & 4386.574 & 4386.576 & 0.002 & 391.5045 & 391.9976 & 0.4931 & 0.5225 & 0.0738 & 7.0774 & 0.6486 \\
\hline 5240 & 4391.219 & 4391.220 & 0.001 & 391.0273 & 391.5208 & 0.4935 & 0.5230 & 0.0736 & 7.1037 & 0.6491 \\
\hline 5243 & 4391.914 & 4391.915 & 0.001 & 390.9559 & 391.4495 & 0.4936 & 0.5231 & 0.0736 & 7.1076 & 0.6492 \\
\hline 5279 & 4400.235 & 4400.235 & 0 & 390.1041 & 390.5984 & 0.4943 & 0.5240 & 0.0732 & 7.1548 & 0.6500 \\
\hline 5300 & 4400.466 & 4400.465 & -0.001 & 390.0806 & 390.5749 & 0.4943 & 0.5240 & 0.0732 & 7.1561 & 0.6501 \\
\hline 5320 & 4409.658 & 4409.656 & -0.002 & 389.1440 & 389.6390 & 0.4950 & 0.5251 & 0.0728 & 7.2084 & 0.6510 \\
\hline
\end{tabular}

In this table $\mathrm{t}_{\mathrm{A}}{ }^{0}$ and $\mathrm{t}_{\mathrm{B}}{ }^{0}$ represent the tax rates of nation $\mathrm{A}$ and $\mathrm{B}$ in the pre-transfer situation, $U^{B}(0)$ is the welfare of nation $B$ prior to the receipt of the transfer, $U^{B}(1)$ is its welfare level after it receives the transfer payment of one unit of good 2 and $\mathrm{dU}^{\mathrm{B}}$ is the change in its welfare level. The other terms have their usual meanings as described in the previous table. This table clearly shows that as $t_{A} / t_{B}$ increases with the increase in the labor endowment of A, this nation becomes a relatively large exporter of good 1 and the effect of immiserization becomes more pronounced. Here transfers received by both 
nations are one unit of good 2. The capital endowments of the two nations are 5000 and 100 and the labor endowment of nation B is 500 . The table supports proposition 4 , which states that when nation A has more market power i.e. $\mathrm{t}_{\mathrm{A}}>\mathrm{t}_{\mathrm{B}}$, it can be immiserized. Also notice that this table shows that $\mathrm{dU}^{\mathrm{B}}$ is positive throughout. This is consistent with proposition 4, which states that the nation with the smaller tax rate cannot be immiserized. 


\subsection{Mathematical Derivations Supporting the Text}

(1) Deriving equation-(2.10) of the text:

Recall the optimal tax rule for nation $\mathrm{A}$ in equation (2.7):

$$
\begin{aligned}
& \mathrm{U}_{1}{ }^{\mathrm{A}} \mathrm{p}_{11}+\mathrm{U}_{2}{ }^{\mathrm{A}}=0 \\
& \Rightarrow \mathrm{U}_{1}{ }^{\mathrm{A}} \frac{p_{1}\left(R_{11}^{A}-E_{11}^{A}\right) E_{U}^{A} U_{3}^{A}}{M L C}+\mathrm{U}_{2}{ }^{\mathrm{A}}=0
\end{aligned}
$$

Substituting for $\mathrm{U}_{2}{ }^{\mathrm{A}}$ we get:

$$
\begin{aligned}
& \left.\mathrm{U}_{1}{ }^{\mathrm{A}} \frac{p_{1}\left(R_{11}^{A}-E_{11}^{A}\right) E_{U}^{A} U_{3}^{A}}{M L C}+\mathrm{t}_{\mathrm{A}} p_{1}^{2}\left(E_{11}^{A}-R_{11}^{A}\right) U_{3}^{A}=0 \text { (substituting for } \mathrm{U}_{2}^{\mathrm{A}}\right) \\
& \Rightarrow \mathrm{p}_{1}\left(R_{11}^{A}-E_{11}^{A}\right) U_{3}^{A}\left[\mathrm{U}_{1}^{\mathrm{A}} \frac{E_{U}^{A}}{M L C}-\mathrm{t}_{\mathrm{A}} \mathrm{p}_{1}\right]=0 \\
& \Rightarrow \mathrm{U}_{1}{ }^{\mathrm{A}} \frac{E_{U}^{A}}{M L C}-\mathrm{t}_{\mathrm{A}} \mathrm{p}_{1}=0
\end{aligned}
$$

Hence $\mathrm{U}_{1}{ }^{\mathrm{A}}=\frac{t_{A} p_{1} M L C}{E_{U}^{A}}$

(2) Deriving equation-(2.13) of the text:

Equating (2.4a) and (2.10) we get:

$$
\begin{aligned}
& \frac{R_{1}^{A}-E_{1}^{A}+t_{A} p_{1}\left(1-t_{A}\right)\left(R_{11}^{A}-E_{11}^{A}\right)}{E_{U}^{A}+t_{A} p_{1} E_{1 U}^{A}}=\frac{t_{A} p_{1} M L C}{E_{U}^{A}} \\
& \Rightarrow \operatorname{Exp}_{1}{ }^{\mathrm{A}}+\mathrm{t}_{\mathrm{A}} \mathrm{p}_{1}\left(1-\mathrm{t}_{\mathrm{A}}\right)\left(R_{11}^{A}-E_{11}^{A}\right)=\left(1+\mathrm{t}_{\mathrm{A}} \mathrm{p}_{1} \mathrm{mpc}_{1 \mathrm{~A}}\right) \mathrm{t}_{\mathrm{A}} \mathrm{p}_{1} \mathrm{MLC}
\end{aligned}
$$

where $\mathrm{mpc}_{1 \mathrm{~A}}=\mathrm{E}_{1 \mathrm{U}}^{\mathrm{A}} / \mathrm{E}_{\mathrm{U}}^{\mathrm{A}}$

$$
\Rightarrow \operatorname{Exp}_{1}{ }^{\mathrm{A}}+\mathrm{t}_{\mathrm{A}} \mathrm{p}_{1}\left[\left(1-\mathrm{t}_{\mathrm{A}}\right)\left(R_{11}^{A}-E_{11}^{A}\right)-\mathrm{MLC}-\mathrm{t}_{\mathrm{A}} \mathrm{p}_{1} \mathrm{MLC} \mathrm{mpc}_{1 \mathrm{~A}}\right]=0
$$


Substituting the value of MLC from the text we have:

$\Rightarrow \operatorname{Exp}_{1}{ }^{\mathrm{A}}+\mathrm{t}_{\mathrm{A}} \mathrm{p}_{1}\left[\mathrm{E}_{1 \mathrm{U}}{ }^{\mathrm{A}} \mathrm{U}_{1}{ }^{\mathrm{A}}-\left(1-\mathrm{t}_{\mathrm{B}}\right)\left(\mathrm{R}_{11}{ }^{\mathrm{B}}-\mathrm{E}_{11}{ }^{\mathrm{B}}\right)+\mathrm{E}_{1 \mathrm{U}}{ }^{\mathrm{B}} \mathrm{U}_{1}{ }^{\mathrm{B}}+\mathrm{E}_{11}{ }^{\mathrm{C}}-\mathrm{g}_{1} \mathrm{~g}_{1 \mathrm{M}}-\mathrm{t}_{\mathrm{A}} \mathrm{p}_{1} \mathrm{MLC}\right.$ $\left.\mathrm{mpc}_{1 \mathrm{~A}}\right]=0$

Using equation (2.10) we get:

$\operatorname{Exp}_{1}{ }^{\mathrm{A}}=\mathrm{t}_{\mathrm{A}} \mathrm{p}_{1}\left[\varepsilon_{1}^{B}-\mathrm{E}_{11}{ }^{\mathrm{C}}+\mathrm{g}_{1} \mathrm{~g}_{1 \mathrm{M}}\right]$

(3) Deriving equation-(2.19) of the text:

Under proportional transfer, using (2.6d) and (2.12), (2.18) can be rewritten as:

$\mathrm{dU}^{\mathrm{A}}=\frac{\left(1-t_{A} p_{1} g_{1 M}\right) \operatorname{Exp}_{1}^{A}}{E_{U}^{A} g_{1}} \mathrm{dg}+\frac{t_{A} p_{1}}{E_{U}^{A}}\left[E_{1 U}^{B} U_{3}^{B}-\mathrm{g}_{1 \mathrm{M}}\right] \frac{\operatorname{Exp}_{1}^{B}}{g_{1}} \mathrm{dg}+\mathrm{U}_{1}{ }^{\mathrm{A}} \mathrm{p}_{12} \mathrm{dt}_{\mathrm{B}}$

Recall from (2.13):

$\operatorname{Exp}_{1}{ }^{\mathrm{A}}=\mathrm{t}_{\mathrm{A}} \mathrm{p}_{1}\left[\mathcal{E}_{1}^{B}-\mathrm{E}_{11}{ }^{\mathrm{C}}+\mathrm{g}_{1} \mathrm{~g}_{1 \mathrm{M}}\right]$

$\Rightarrow \operatorname{Exp}_{1}{ }^{\mathrm{A}}\left(1-\mathrm{t}_{\mathrm{A}} \mathrm{p}_{1} \mathrm{~g}_{1 \mathrm{M}}\right)=\mathrm{t}_{\mathrm{A}} \mathrm{p}_{1}\left(\varepsilon_{1}^{B}-\mathrm{E}_{11}^{\mathrm{C}}+\operatorname{Exp}_{1}^{B} \mathrm{~g}_{1 \mathrm{M}}\right)$

Hence (2.18) becomes,

$\mathrm{dU}^{\mathrm{A}} / \mathrm{dg}=\left[\mathrm{t}_{\mathrm{A}} \mathrm{p}_{1}\left(\mathcal{E}_{1}^{B}-\mathrm{E}_{11}{ }^{\mathrm{C}}+\operatorname{Exp}_{1}^{B} \mathrm{~g}_{1 \mathrm{M}}\right)\right] / \mathrm{E}_{\mathrm{U}}^{\mathrm{A}} \mathrm{g}_{1}+\left[\mathrm{t}_{\mathrm{A}} \mathrm{p}_{1}\left(E_{1 U}^{B} U_{3}^{B}-\mathrm{g}_{1 \mathrm{M}}\right)\right] / \mathrm{E}_{\mathrm{U}}{ }^{\mathrm{A}} \mathrm{g}_{1}+$ $\mathrm{U}_{1}^{\mathrm{A}} \mathrm{p}_{12} \mathrm{dt}_{\mathrm{B}}$

$=\left[\mathrm{t}_{\mathrm{A}} \mathrm{p}_{1}\left(\mathcal{E}_{1}^{B}-\mathrm{E}_{11}{ }^{\mathrm{C}}+\operatorname{Exp}_{1}^{B} E_{1 U}^{B} U_{3}^{B}\right)\right] / \mathrm{E}_{\mathrm{U}}{ }^{\mathrm{A}} \mathrm{g}_{1}+\mathrm{U}_{1}{ }^{\mathrm{A}} \mathrm{p}_{12} \mathrm{dt}_{\mathrm{B}}$

Now consider, $\mathcal{E}_{1}^{B}+\operatorname{Exp}_{1}^{B} E_{1 U}^{B} U_{3}^{B}$

where, $\left.\varepsilon_{1}^{B}=\left(1-\mathrm{t}_{\mathrm{B}}\right)\right)\left(\mathrm{R}_{11}{ }^{\mathrm{B}}-\mathrm{E}_{11}{ }^{\mathrm{B}}\right)-\mathrm{E}_{1 \mathrm{U}}{ }^{\mathrm{B}} \mathrm{U}_{1}^{\mathrm{B}}$ 
and $U_{1}{ }^{B}=\left[\operatorname{Exp}_{1}{ }^{B}+t_{B} p_{1}\left(1-t_{B}\right)\left(R_{11}{ }^{B}-E_{11}{ }^{B}\right)\right] U_{3}{ }^{B}$

Hence, $\mathcal{E}_{1}^{B}+\operatorname{Exp}_{1}^{B} E_{1 U}^{B} U_{3}^{B}=\left(1-\mathrm{t}_{\mathrm{B}}\right)\left(\mathrm{R}_{11}{ }^{\mathrm{B}}-\mathrm{E}_{11}{ }^{\mathrm{B}}\right)\left[1-\mathrm{t}_{\mathrm{B}} \mathrm{p}_{1} \mathrm{E}_{1 \mathrm{U}}{ }^{\mathrm{B}} \mathrm{U}_{3}{ }^{\mathrm{B}}\right]$

$=\left(1-\mathrm{t}_{\mathrm{B}}\right)\left(\mathrm{R}_{11}^{\mathrm{B}}-\mathrm{E}_{11}^{\mathrm{B}}\right)-\mathrm{t}_{\mathrm{B}} \mathrm{p}_{1}\left(\frac{\left(1-t_{B}\right)\left(R_{11}^{B}-E_{11}^{B}\right) E_{1 U}^{B}}{E_{U}^{B}+t_{B} p_{1} E_{1 U}^{B}}\right)$

$=\frac{\left(1-t_{B}\right)\left(R_{11}^{B}-E_{11}^{B}\right) E_{U}^{B}}{E_{U}^{B}+t_{B} p_{1} E_{1 U}^{B}}>0$

This implies, $\mathrm{dU}^{\mathrm{A}} / \mathrm{dg}=\left[\mathrm{t}_{\mathrm{A}} \mathrm{p}_{1}\left(\frac{\left(1-t_{B}\right)\left(R_{11}^{B}-E_{11}^{B}\right) E_{U}^{B}}{E_{U}^{B}+t_{B} p_{1} E_{1 U}^{B}}-\mathrm{E}_{11}{ }^{\mathrm{C}}\right)\right] \mathrm{E}_{\mathrm{U}}{ }^{\mathrm{A}} \mathrm{g}_{1}+\mathrm{U}_{1}{ }^{\mathrm{A}} \mathrm{p}_{12} \mathrm{dt}_{\mathrm{B}}>0$

provided the tax response of B is sufficiently small.

(4) Deriving equation-(2.22):

Under optimal taxation and equal transfer:

$\mathrm{dU}^{\mathrm{A}} / \mathrm{dg}=\frac{1-t_{A} p_{1} g_{1 M}}{E_{U}^{A}}+\mathrm{U}_{1}{ }^{\mathrm{A}} \mathrm{p}_{14}+\mathrm{U}_{1}{ }^{\mathrm{A}} \mathrm{p}_{12} \mathrm{dt}_{\mathrm{B}} / \mathrm{dg}$

Now, $\mathrm{U}_{1}^{\mathrm{A}} \mathrm{p}_{14}+\frac{\left(1-t_{A} p_{1} g_{1 M}\right)}{E_{U}^{A}}=\frac{\mathrm{U}_{1}^{\mathrm{A}}\left(E_{1 U}^{B} U_{3}^{B}-g_{1 M}\right)}{M L C}+\frac{\left(1-t_{A} p_{1} g_{1 M}\right)}{E_{U}^{A}}$

$=\frac{t_{A} p_{1}\left(E_{1 U}^{B} U_{3}^{B}-g_{1 M}\right)}{E_{U}^{A}}+\frac{\left(1-t_{A} p_{1} g_{1 M}\right)}{E_{U}^{A}}$

Since, $\mathrm{p}_{14}=\frac{E_{1 U}^{B} U_{3}^{B}-g_{1 M}}{M L C}$ from (2.6d)

Now the numerator of the expression can be rewritten as:

$\mathrm{t}_{\mathrm{A}} \mathrm{p}_{1}\left(\frac{m p c_{1 B}}{1+t_{B} m p c_{1 B}}-\mathrm{g}_{1 \mathrm{M}}\right)+1-\mathrm{t}_{\mathrm{A}} \mathrm{p}_{1} \mathrm{~g}_{1 \mathrm{M}}$

Using $\varphi_{11}=E_{11}^{C}-\mathrm{g}_{1} \mathrm{~g}_{1 \mathrm{M}}$ and $\operatorname{Exp}_{1}^{A}=\mathrm{t}_{\mathrm{A}} \mathrm{p}_{1}\left(\varepsilon_{1}^{B}-\varphi_{11}\right)$, it can be shown that: 
$1-\mathrm{t}_{\mathrm{A}} \mathrm{p}_{1} \mathrm{~g}_{1 \mathrm{M}}=\frac{t_{A} p_{1}\left(\varepsilon_{1}^{B}-E_{11}^{C}\right)+\operatorname{Exp}_{1}^{B}}{g_{1}}$

Hence, $\mathrm{t}_{\mathrm{A}} \mathrm{p}_{1}\left(\frac{m p c_{1 B}}{1+t_{B} m p c_{1 B}}-\mathrm{g}_{1 \mathrm{M}}\right)+1-\mathrm{t}_{\mathrm{A}} \mathrm{p}_{1} \mathrm{~g}_{1 \mathrm{M}}$

$=\frac{t_{A} p_{1}}{g_{1}}\left[\frac{m p c_{1 B} g_{1}}{1+t_{B} m p c_{1 B}}-\mathrm{g}_{1} \mathrm{~g}_{1 \mathrm{M}}+\varepsilon_{1}^{B}-E_{11}^{C}+\frac{\operatorname{Exp}_{1}^{B}}{t_{A} p_{1}}\right]$

Consider, $\frac{m p c_{1 B} g_{1}}{1+t_{B} m p c_{1 B}}-\mathrm{g}_{1} \mathrm{~g}_{1 \mathrm{M}}+\varepsilon_{1}^{B}-E_{11}^{C}+\frac{\operatorname{Exp}_{1}^{B}}{t_{A} p_{1}}$

$=U_{3}^{B} E_{1 U}^{B}\left(\operatorname{Exp}_{1}^{A}+\operatorname{Exp}_{1}^{B}\right)-\mathrm{g}_{1} \mathrm{~g}_{1 \mathrm{M}}+\varepsilon_{1}^{B}-E_{11}^{C}+\frac{\operatorname{Exp}_{1}^{B}}{t_{A} p_{1}}$

Note: $m p c_{1}^{B}=E_{1 U}^{B} / E_{U}^{B}$

Now, $\left.\mathcal{E}_{1}^{B}=\left(1-\mathrm{t}_{\mathrm{B}}\right)\right)\left(\mathrm{R}_{11}{ }^{\mathrm{B}}-\mathrm{E}_{11}{ }^{\mathrm{B}}\right)-\mathrm{E}_{1 \mathrm{U}}{ }^{\mathrm{B}} \mathrm{U}_{1}{ }^{\mathrm{B}}$ and $\mathrm{U}_{1}{ }^{\mathrm{B}}=\left[\mathrm{Exp}_{1}{ }^{\mathrm{B}}+\mathrm{t}_{\mathrm{B}} \mathrm{p}_{1}\left(1-\mathrm{t}_{\mathrm{B}}\right)\left(\mathrm{R}_{11}{ }^{\mathrm{B}}-\mathrm{E}_{11}{ }^{\mathrm{B}}\right)\right] \mathrm{U}_{3}{ }^{\mathrm{B}}$

Hence, $U_{3}^{B} E_{1 U}^{B} \operatorname{Exp}_{1}^{B}+\varepsilon_{1}^{B}=\left(1-\mathrm{t}_{\mathrm{B}}\right)\left(R_{11}^{B}-E_{11}^{B}\right) E_{U}^{B} U_{3}^{B}$

From the optimal tax rule of B:

$\operatorname{Exp}_{1}^{B}=\mathrm{t}_{\mathrm{B}} \mathrm{p}_{1}\left(\varepsilon_{1}^{A}-\varphi_{11}\right)$

Hence the numerator of expression (2.22)

$$
\begin{aligned}
& \mathrm{t}_{\mathrm{A}} \mathrm{p}_{1}\left(\frac{m p c_{1 B}}{1+t_{B} m p c_{1 B}}-\mathrm{g}_{1 \mathrm{M}}\right)+1-\mathrm{t}_{\mathrm{A}} \mathrm{p}_{1} \mathrm{~g}_{1 \mathrm{M}}=\frac{m p c_{1 B} g_{1}}{1+t_{B} m p c_{1 B}}-\mathrm{g}_{1} \mathrm{~g}_{1 \mathrm{M}}+\varepsilon_{1}^{B}-E_{11}^{C}+\frac{\operatorname{Exp}_{1}^{B}}{t_{A} p_{1}} \\
& =U_{3}^{B} E_{1 U}^{B} \operatorname{Exp}_{1}^{A}-E_{11}^{C}+\left(1-\mathrm{t}_{\mathrm{B}}\right)\left(R_{11}^{B}-E_{11}^{B}\right) E_{U}^{B} U_{3}^{B}+\frac{t_{B}}{t_{A}}\left(\varepsilon_{1}^{A}-E_{11}^{C}\right)+\left(\frac{t_{B}}{t_{A}}-1\right) \mathrm{g}_{1} \mathrm{~g}_{1 \mathrm{M}}
\end{aligned}
$$

Thus we have (2.22):

$\mathrm{U}_{1}^{\mathrm{A}} \mathrm{p}_{14}+\frac{\left(1-t_{A} p_{1} g_{1 M}\right)}{E_{U}^{A}}=\frac{t_{A} p_{1}\left(E_{1 U}^{B} U_{3}^{B}-g_{1 M}\right)}{E_{U}^{A}}+\frac{\left(1-t_{A} p_{1} g_{1 M}\right)}{E_{U}^{A}}$ 


$$
=\frac{t_{A} p_{1}}{g_{1} E_{U}^{A}}\left[U_{3}^{B} E_{1 U}^{B} \operatorname{Exp}_{1}^{A}-E_{11}^{C}+\left(1-\mathrm{t}_{\mathrm{B}}\right)\left(R_{11}^{B}-E_{11}^{B}\right) E_{U}^{B} U_{3}^{B}+\frac{t_{B}}{t_{A}}\left(\varepsilon_{1}^{A}-E_{11}^{C}\right)+\left(\frac{t_{B}}{t_{A}}-1\right) \mathrm{g}_{1} \mathrm{~g}_{1 \mathrm{M}}\right]
$$




\section{Chapter 3}

\section{Trade Liberalization and Illegal Immigration between Mexico and the United States}

\subsection{Introduction}

Trade liberalization has gained considerable attention globally in the past couple of decades. The European Community (EC) and the European Free Trade Association (EFTA) were pioneers, and were formed to reduce internal tariffs for all products over a specific period. The North American Free Trade Agreement (NAFTA) was intended to liberalize trade among the U.S., Canada, and Mexico. In fact, between 1985 and 1989, the U.S. and Mexico had signed three major trade agreements, but NAFTA was definitely the beginning of a new era.

NAFTA was signed by the governments of the United States, Mexico, and Canada on December 17, 1992. It took effect on January 1, 1994 with the objective of reduction and eventual elimination of trade and investment barriers within North America. The main provision of NAFTA was the elimination of all import tariffs on manufactured and agricultural products traded among the three countries. Some tariffs were eliminated as soon as the agreement became effective, while others were to be phased out over 5,10 , or 15 years $^{6}$.

\footnotetext{
${ }^{6}$ Hufbauer and Schott(1993) discuss the particulars of these phase -out schedules.
} 
Many economists argue that the effects of NAFTA on the undocumented labor flow from Mexico to the U.S. will not be visible until ten years after the act went into effect. The undocumented labor flow from Mexico constitutes about one-third of the total illegal immigration to the U.S. This is the rationale behind studying the impact on illegal immigration only from Mexico. Also, the focus is on trade liberalization over a period of the last 25-30 years rather than the post-NAFTA period. This is because NAFTA is likely to have a less significant impact on illegal immigration in less than a decade. However, tariff liberalization that these countries have witnessed for the last two decades may have a more pronounced effect on the undocumented labor flow form Mexico to the United States.

According to Espenshade (1995) the study of this undocumented labor flow is a very difficult issue, since it is unobserved and hence the figure estimated is imprecise. The most popular proxy used to measure illegal immigration is the number of people apprehended at the U.S. border. Espenshade (1995) also suggests that the correlation between the number of apprehensions and the estimated level of illegal immigrants is 0.90. This study attempts to capture the effects of trade liberalization on the number of people apprehended at the border for the period 1970-1998.

The essay is composed of ten sections. Section 3.2 and 3.3 present the issue of illegal immigration. Section 3.4 discusses the concept of trade liberalization, particularly in the context of NAFTA. The linkages between illegal immigration and trade liberalization are discussed in section 3.5. A theoretical model of illegal immigration is presented in section 
3.6. Sections 3.7, 3.8 and \& 3.9 discuss the empirical model, the data and the estimation results. Finally, section 3.10 presents the conclusion of the paper.

\subsection{Illegal Immigration: The Policy Debate}

Immigration has been an issue of major political debate in the United States for decades. On one hand, organizations like the Federation for American Immigration Reform (FAIR) argue that immigration is causing too much strain on the U.S. labor market and hence should be controlled rigorously. Economists are of the opinion that the illegal workers displace unskilled or low-skilled native workers from their jobs and also put downward pressure on wages (Greenwood and McDowell, 1986). Illegal immigrants are also believed to reduce the pace of structural adjustment and technological progress and thus retard the economy's competitiveness in the international market (Harrison, 1992). It is argued that illegal workers draw benefits from U.S. social programs without making equivalent contribution to the programs' budgets. At the other extreme there are proponents advocating immigration. On July 3, 1986, the Wall Street Journal proposed "there shall be open borders" that was again republished in an editorial on July 3, 1990. Julian Simon (1981) argues, "admitting immigrants improves our standard of living". There are other proponents advocating the need for illegal immigrants, who argue that low-skilled foreign workers are beneficial for the economy. Especially the agricultural sector of Southern California and Texas and garment industries of big cities like New York and Los Angeles require cheap labor. Espenshade (1995) argues that there is very little evidence that illegal immigrants have adverse labor market impacts. 
Due to the overwhelming number of immigrants to the U.S. in recent years, this issue has gained considerable attention. One of the pioneering works in the field of illegal immigration is by Ethier (1986). Ethier studied the implications of several immigration policies and enforcement measures for the level of welfare and distribution of income in the host country. Bond and Chen (1987) extended Ethier's results by examining the optimal level of enforcement in a two-country model, and also studied the effects of capital mobility.

Aliens or non-U.S. citizens can be broadly classified into three categories: (1) immigrants (people who have been granted permits that allow them to live and work in the United States permanently); (2) nonimmigrants, (people who are granted temporary visas to the U.S. to visit, work or study); and (3) illegal immigrants (those without any legal permits). The Immigration and Naturalization Service (INS) has the responsibility of enforcing immigration laws in the U.S. The most difficult tasks that the INS has to perform are to locate individuals who successfully complete an illegal entry; and aliens who have entered the country legally but have lost their legal status; and also to arrest individuals at the border (Statistical Yearbook of the INS, 1999).

The U.S. government has been actively taking action to control the number of illegal immigrants for more than a decade. The Immigration and Reform Control Act (IRCA) of 1986 and the Immigration Act of 1990 were two major policies in this direction. IRCA was implemented in 1987, authorizing increased resources to curb illegal immigration and also raising sanctions on employers hiring illegal aliens. 
There are mixed opinions about the impact of IRCA on illegal immigration. There has been a decline in the number of illegal immigrants in the post-IRCA period after controlling for factors like wages and unemployment level that can affect illegal immigration. This made Bean et al. (1990), Espenshade (1990), White, Bean and Espenshade (1990) believe that IRCA, in fact, has accomplished its targeted goal of reducing illegal immigration. However, Donato, Durand, and Massey (1992) find no evidence that IRCA has significantly deterred illegal immigration from Mexico. Bustamante (1990) found that there was little change in the daily number of people crossing the U.S.-Mexico border at two locations as a consequence of IRCA. Acevedo and Espenshade (1992) point out that the U.S. Immigration Reform and Control Act (IRCA) passed by the Congress in 1986 tried to control the illegal labor flow solely through enforcement and had minimal success. Hill and Pearce (1990) found that sanctions reduce the supply of illegal labor force by $11 \%$ when the border patrol budget is limited; however, at a substantially high level of budget allocation, the illegal workforce may be reduced by $50 \%$. Clearly, the border patrol budget has a crucial role to play in apprehending illegal aliens at the border. The Immigration Act was effective in 1992. It required caps on legal immigration and also revised the legal admission procedure to facilitate the entry of family members of U.S. citizens. The estimated total number of undocumented illegal immigrants residing in the U.S. in 1996 was 5.0 million, varying in the range between 4.6 to 5.4 million. In 1992 the estimated total was 3.4 million, implying the growth of illegal aliens at the rate of 275,000 per annum between 1992 and 1996. 


\subsection{Mexican Maquiladora System and Its Impact on Illegal Immigration}

The Maquiladora System provides a low-cost method of producing goods. Foreign components and also any machinery required to assemble the components are imported duty-free into Mexico and then the finished goods are re-exported, generally to the United States. Duties imposed on the finished goods are significantly low to account for the value that was added in assembling the product. Automobile and electronics industries are based on maquiladora employment.

The question is whether the maquiladora system increases the undocumented labor flow from Mexico to the U.S. Seligson and Williams (1981), Sklair (1989), Brannon and Lucker(1988) and Dávila and Saenz (1990) find no relationship between maquiladoras and migration. A survey by Huerta (1990) suggests that $28 \%$ of maquiladora workers felt that their maquiladora training would help them find a job in the U.S. About $16 \%$ of the workers Huerta interviewed, expressed the desire to enter the U.S. illegally. However, Huerta concludes that maquiladora draws people to border areas in Mexico, but it does not necessarily lead to an increase in migration to the U.S. According to Martin (1993), if the maquiladora industry expands due to foreign direct investment stimulated by NAFTA, then the expansion is not likely to increase the flow of undocumented labor flow into the U.S. in the same proportion. However, the relationship between the growth of maquiladora industry and illegal immigration into the U.S. is slightly positive. Hence, it is best to encourage the growth of the maquiladora industry somewhere far from the border in order to reduce illegal labor flow into the United States. 


\subsection{Trade Liberalization as Captured in NAFTA}

Tariff liberalization did not start in the U.S. and Mexico with the negotiation of NAFTA. Much before the signing of this agreement the U.S. had been experiencing tariff liberalization both under the WTO and the GATT. The U.S. and Canada had entered into a Free Trade Agreement in 1989. This agreement and other preferential trading arrangements have affected the trade patterns in the U.S. and also influenced illegal immigration. As pointed out by Anne Krueger (1999) Mexico had already begun to liberalize trade in the mid 1980s. Mexico had removed all quantitative restrictions on imports by 1990. The tariff rates were reduced to an average level of $10 \%$ against U.S. imports compared to the U.S. average level of $4 \%$ for imports from Mexico. This emphasizes the fact that NAFTA was only a formal agreement to bring further trade liberalization that had already started in the 80 's.

NAFTA is an extended version of the Canada-U.S. FTA with the inclusion of Mexico. The main provision of NAFTA is a phased elimination of tariff and nontariff barriers among the member countries within 10 years, with the exception of few import-sensitive products that will be eliminated in 15 years. Also, NAFTA emphasizes investment opportunities, particularly in key Mexican sectors, such as petrochemicals and financial services (Hufbauer and Schott, 1993). The objective of NAFTA is to widen the scope of the market and enlarge the available labor force, thus making North American firms and workers more competitive in the home and world markets. Whatever be the objectives of 
NAFTA the question remains - what will be its effects? NAFTA is expected to increase the foreign direct investment in Mexico.

As Hufbauer and Schott (1993) observe even before NAFTA took effect in 1994, it had generated strong expectations. Capital inflows in Mexico were estimated to be around $\$ 18$ billion in 1992, a large portion of which (approximately $\$ 5$ billion) was foreign direct investment. The Cuomo Commission on Competitiveness (1992) also emphasized a similar impact of NAFTA as it expected that NAFTA would shift new plant and equipment investment from the U.S. to Mexico. According to Koechlin and Larudee (1992), the increased investment flows from the United States to Mexico will increase the capital stock in Mexico from $\$ 31$ billion to $\$ 53$ billion between 1992 and 2000, which will cause the U.S. capital stock to decrease by an equivalent amount. They come to a very pessimistic conclusion from this assumption, which says that the United States will lose 290,000 to 490,000 industrial jobs, while Mexico will gain 400,000 to 680,000 . However, this argument has a positive aspect as noted by Sherman Robinson et al. (1992). They devise a computable general equilibrium model to show that $1 \%$ increase in Mexican capital stock reduces the level of permanent migration from Mexico to the United States by about 44,000 workers. Hence, an increase of $\$ 31$ billion to $\$ 53$ billion capital stock over approximately $\$ 500$ billion in 1990 will lead to a reduction of permanent immigration by at least 260,000 . This brings our focus to the migration effects of NAFTA, particularly trade liberalization, which is discussed in the next section. 


\subsection{Trade Liberalization and Illegal Immigration: What are the Linkages}

The purpose of NAFTA is to stimulate economic development and job growth in Mexico, the U.S., and Canada. The effects of NAFTA or trade liberalization may be analyzed in the context of the Heckscher-Ohlin-Samuelson type model. According to this theory, trade liberalization should raise unskilled labor wages in Mexico since Mexico is relatively abundant in unskilled labor. Similarly, U.S. unskilled wages should fall leading to convergence in the wages of the two countries. The wage gap reduction will reduce the incentive to migrate from Mexico to the U.S. We focus only on unskilled Mexican workers, since they are the ones who seek to cross the border illegally.

Trade liberalization is expected to close the wage gap between Mexico and the U.S. (Weintraub, 1984, p.174) and thus reduce the flow of undocumented labor between the two countries. However, there are several economists who do not believe in the Heckscher-Ohlin mechanism as an appropriate description of U.S.-Mexico migration. Feenstra and Hanson (1995, 1997), Markusen and Venables (1997, 1998), and Markusen and Zahniser (1997) are of the opinion that the Heckscher-Ohlin mechanism will not operate in favor of unskilled labor in Mexico and hence will not reduce incentive for migration.

Martin (1993) argues that in the short to medium run, migration pressure may increase. He discusses several models and methodologies, all suggesting that NAFTA or trade liberalization will not eliminate the pressure of illegal immigration in the near future. 
The argument is that a large percentage of the Mexican workforce is engaged in agriculture and due to the changes in Mexican farm policies and free trade in agricultural products associated with NAFTA; many of these Mexicans are going to lose their jobs. If new jobs are not created for these displaced farmers, then they are expected to migrate. According to Hinojosa and Robinson (1991), there will be 600,000 additional U.S.-bound immigrants, both legal and illegal, as a result of NAFTA. In Hinojosa and McCleery's (1992) words: "An FTA by itself is not capable of reducing migration as some have claimed. Migration, in fact, will increase substantially in the absence of significant capital inflows to increase employment and wages in Mexico." A study by the National Commission for Employment Policy (1992) indicates that between 4 and 5 million Mexican people are expected to enter the U.S. both legally and illegally without taking the effects of NAFTA into consideration. According to Martin (1992), most of the immigrants are expected to return to Mexico. However, a small proportion of them, perhaps $10 \%$ will settle permanently in the U.S. It is possible that in the short run NAFTA will marginally increase the number of Mexican illegal immigrants. However, it is expected that in the long run, tariff liberalization will stimulate economic growth, create new jobs within Mexico, and hence reduce the problem of illegal labor flow.

Some proponents have argued that without NAFTA the number of incoming illegal immigrants would have been higher. For example it has been speculated that if NAFTA, had not been approved, there may be 500,000 additional illegal Mexican immigrants annually (The Wall Street Journal, 28 May, 1993, A7). It is assumed that many potential migrants are remaining in Mexico in the hope that freer trade will create new jobs for 
them. Nevertheless, NAFTA is expected to boost the Mexican economy. The National Commission for Employment Policy (1992) predicts that in the first decade of the 21st century there will be a decrease in the number of Mexican immigrants. According to the calculations of the consulting firm CIEMEX-WEFA (1992) the gross number of illegal immigrants would drop by 600,000 as a result of productivity being boosted by NAFTA.

It is unclear at this point how trade liberalization will affect illegal immigration. Based on the Heckscher-Ohlin theorem, which demonstrates the tendency for factor-price equalization as a consequence of free trade, the prediction may be due to trade liberalization the wage gap between the U.S. and Mexico reduces. This in turn, cuts the volume of illegal labor inflow into the United States. However, there are opposing views arguing that the undocumented labor flow will increase because Mexican workers engaged in agriculture will lose their jobs due to policies involved with trade liberalization and try to seek employment in the U.S. Brown et al. (1992) argue that the inflow of capital into Mexico would enable the unemployed agricultural workers in Mexico to find employment opportunities in the growing manufacturing sectors, thereby reducing illegal immigration. On the other hand, Schiff (1994), Lopez and Schiff (1995) argue that trade liberalization may increase illegal immigration. Their finding is based on the fact that migration is costly and once the unskilled workers in Mexico receive higher wages (due to trade liberalization) it will be easier for them to finance the cost of migration. The effect of trade liberalization on illegal immigration has been an issue of policy debate for years and a-priori it is hard to tell what will happen to illegal immigration and this study attempts to shed light on this issue. 


\subsection{The Theoretical Model}

The theoretical model presented here is a small-union Meade model (similar to Bandyopadhyay, $2001^{7}$ ) where there are three nations: the U.S., Mexico and the rest of the world. Mexico and the U.S. are small nations compared to the rest of the world. In the model, there are two goods 1 and 2, where the U.S. imports good 1, Mexico imports good 2, and both the goods are imported by the rest of the world. The U.S imposes tariff rate $\mathrm{t}_{1}{ }^{\mathrm{US}}$ on good 1 and Mexico imposes tariff rate $\mathrm{t}_{2}{ }^{\mathrm{mex}}$ on good 2. Prices of the two goods are exogenously given in the model and are normalized to unity. Wage rate in the U.S., $\mathrm{w}^{\text {US }}$ is greater than wage rate in Mexico, $\mathrm{w}^{\mathrm{mex}}$. Due to this difference in the wage rate, there is an undocumented labor flow from Mexico to the U.S. Although, in reality, there are unemployment rates in both the economies, for simplicity of the model we assume full employment. In the empirical analysis unemployment rates will be taken into consideration. With the level of border enforcement used by the U.S. denoted by e, the probability of border detection $\mathrm{p}$ is then expressed as:

$$
\mathrm{p}=\mathrm{p}(\mathrm{e}) \text { where } 1>\mathrm{p}^{\prime}>0 \text { and } \mathrm{p}^{\prime \prime}<0
$$

The unskilled workers in Mexico can either remain in Mexico and earn $\mathrm{w}^{\text {mex }}$ or they can attempt to cross the border illegally. If they are successful in crossing the border, then they can earn $\mathrm{w}^{\mathrm{US}} \cdot{ }^{8}$ However, unsuccessful immigrants have to pay a penalty $\theta$ and end up earning $\mathrm{w}^{\mathrm{mex}}-\theta$. Assuming Mexican unskilled workers are risk-neutral, a potential

\footnotetext{
${ }^{7}$ Bandyopadhyay's (2001) focus is on second best tariffs and quite different from the issues addressed here. ${ }^{8}$ As Ethier(1986) points out that the firms cannot distinguish between legal and illegal immigrants or the distinction does not have any implications.
} 
immigrant equates the expected wage from illegal immigration to the certainty wage rate in Mexico.

$\left(w^{\operatorname{mex}}-\theta\right) p+w^{U S}(1-p)=w^{\text {mex }}$

$\Rightarrow \mathrm{w}^{\mathrm{mex}}=\mathrm{w}^{\mathrm{US}}-\theta(\mathrm{p}(\mathrm{e}) /(1-\mathrm{p}(\mathrm{e}))$

Let $p(e) /(1-p(e))=\lambda(e)$

Hence, $\left(3.2^{\prime}\right)$ reduces to

$\mathrm{w}^{\mathrm{mex}}=\mathrm{w}^{\mathrm{US}}-\theta \lambda(\mathrm{e}) \quad$ where $\lambda^{\prime}>0$

Let $\mathrm{I}$ be the level of illegal immigration from Mexico to the U.S., $\mathrm{K}_{\mathrm{ex}}$ is foreign direct investment from the U.S. to Mexico and $\mathrm{L}^{\mathrm{i}}$ and $\mathrm{K}^{\mathrm{i}}$ are the labor and capital endowments of nation $\mathrm{i}$, where $\mathrm{i}=\mathrm{U} . \mathrm{S}$., Mexico. The rental rates of the two nations are $\mathrm{r}^{\mathrm{US}}$ and $\mathrm{r}^{\mathrm{mex}}$.

The expenditure-revenue relationship of the U.S. can be written as:

$\mathrm{E}^{\mathrm{us}}\left(1+\mathrm{t}_{1}{ }_{\mathrm{US}}, 1, \mathrm{U}^{\mathrm{US}}\right)=\mathrm{R}^{\mathrm{us}}\left(1+\mathrm{t}_{1}{ }^{\mathrm{US}}, 1, \mathrm{~L}^{\mathrm{US}}+\mathrm{I}, \mathrm{K}^{\mathrm{US}}-\mathrm{K}_{\mathrm{ex}}\right)+\mathrm{t}_{1}{ }^{\mathrm{US}}\left(\mathrm{E}_{1}{ }^{\mathrm{US}}-\mathrm{R}_{1}{ }^{\mathrm{US}}\right)-\mathrm{e}+\mathrm{r}^{\mathrm{mex}} \mathrm{K}_{\mathrm{ex}}$

where $r^{\text {mex }} K_{e x}$ is the receipt of payment for the investment made.

Similarly, the expenditure-revenue relationship for Mexico can be written as:

$\mathrm{E}^{\mathrm{mex}}\left(1,1+\mathrm{t}_{2}{ }^{\mathrm{mex}}, \mathrm{U}^{\mathrm{mex}}\right)=\mathrm{R}^{\mathrm{mex}}\left(1,1+\mathrm{t}_{2}{ }^{\mathrm{mex}}, 1, \mathrm{~L}^{\mathrm{mex}}-\mathrm{I}, \mathrm{K}^{\mathrm{mex}}+\mathrm{K}_{\mathrm{ex}}\right)+\mathrm{t}_{2}{ }^{\mathrm{mex}}\left(\mathrm{E}_{1}{ }^{\mathrm{mex}}-\mathrm{R}_{1}{ }^{\mathrm{mex}}\right)-\mathrm{r}^{\mathrm{mex}} \mathrm{K}_{\mathrm{ex}}$

Consider a situation where foreign direct investment is a policy variable. Note that the partial of the revenue function with respect to factor endowment yields the factor reward vector. Hence, using (3.2") we have:

$\mathrm{R}_{\mathrm{L}}{ }^{\mathrm{mex}}\left(1,1+\mathrm{t}_{2}{ }^{\mathrm{mex}}, \mathrm{L}^{\mathrm{mex}}-\mathrm{I}, \mathrm{K}^{\mathrm{mex}}+\mathrm{K}_{\mathrm{ex}}\right)-\mathrm{R}_{\mathrm{L}}{ }^{\mathrm{US}}\left(1+\mathrm{t}_{1}{ }^{\mathrm{US}}, 1, \mathrm{~L}^{\mathrm{US}}+\mathrm{I}, \mathrm{K}^{\mathrm{US}}-\mathrm{K}_{\mathrm{ex}}\right)+\theta \lambda(\mathrm{e})=0$

Equation (3.5) implicitly defines: 
$\mathrm{I}=\mathrm{I}\left(\mathrm{e}, \mathrm{t}_{1}{ }^{\mathrm{US}}, \mathrm{t}_{2}{ }^{\mathrm{mex}}, \mathrm{K}_{\mathrm{ex}}\right)$

Let us assume that revenue function is strictly concave in $\mathrm{L}$ for both nations such that $\mathrm{R}_{\mathrm{LL}}{ }^{\text {mex }}<0$ and $\mathrm{R}_{\mathrm{LL}}{ }^{\text {us }}<0$. Let $\mathrm{D}=\mathrm{R}_{\mathrm{LL}}{ }^{\text {mex }}+\mathrm{R}_{\mathrm{LL}}{ }^{\text {us }}<0$. Using (3.5) and (3.6) we have,

$\mathrm{I}_{1}=\partial \mathrm{I} / \partial \mathrm{e}=\theta \lambda^{\prime}(\mathrm{e}) / \mathrm{D}<0$

This implies that an increase in border enforcement will lead to a reduction in the level of illegal immigration.

$\mathrm{I}_{2}=\partial \mathrm{I} / \partial \mathrm{t}_{1}{ }^{\mathrm{US}}=-\mathrm{R}_{\mathrm{L} 1}{ }^{\mathrm{us}} / \mathrm{D}$

$\mathrm{I}_{3}=\partial \mathrm{I} / \partial \mathrm{t}_{2}{ }^{\mathrm{mex}}=\mathrm{R}_{\mathrm{L} 2}{ }^{\mathrm{mex}} / \mathrm{D}$

Equation (3.8) implies that if a tariff decrease in the U.S. on good 1 reduces the wage rate in the U.S.(i.e. $\mathrm{R}_{\mathrm{L} 1}{ }^{\mathrm{us}}>0$ ), then it must reduce immigration. Similarly (3.9) implies that if a reduction in the tariff rate of Mexico on good 2 increases the wage rate of Mexico (i.e. $\mathrm{R}_{\mathrm{L} 2}{ }^{\text {mex }}<0$ ), then it must reduce illegal immigration. This is consistent with the findings of the Heckscher-Ohlin model.

$\mathrm{I}_{4}=\partial \mathrm{I} / \partial \mathrm{K}_{\mathrm{ex}}=\left(\mathrm{R}_{\mathrm{LK}}{ }^{\mathrm{mex}}+\mathrm{R}_{\mathrm{LK}}{ }^{\mathrm{us}}\right) / \mathrm{D}=\mathrm{R}_{\mathrm{LK}}{ }^{\mathrm{mex}} / \mathrm{D}+\mathrm{R}_{\mathrm{LK}}{ }^{\mathrm{us}} / \mathrm{D}$

Equation (3.10) implies that if a capital increase in Mexico raises the wage rate (i.e. $\mathrm{R}_{\mathrm{LK}}^{\mathrm{mex}}>0$ ) then it must reduce illegal immigration. Similarly if a decline in capital endowment in the U.S. (or increase in $K_{e x}$ ) reduces the wage rate (i.e. $R_{L K}{ }^{U S}>0$ ), then it must reduce illegal immigration. The argument made above implies that if a foreign direct investment from the U.S. to Mexico reduces the wage gap between the two countries, then it should reduce illegal immigration. 
Hence, the effect of border enforcement is negative, but the effect of tariff changes and foreign direct investment are ambiguous and depend on their effect on wage rates in each nation.

Totally differentiating (3.6) we get:

$\mathrm{dI}=\left(\partial \mathrm{I} / \partial \mathrm{e} \mathrm{de}+\partial \mathrm{I} / \partial \mathrm{K}_{\mathrm{ex}} \mathrm{dK}_{\mathrm{ex}}\right)+\left(\partial \mathrm{I} / \partial \mathrm{t}_{1}{ }^{\mathrm{US}} \mathrm{dt}_{1}{ }^{\mathrm{US}}+\partial \mathrm{I} / \partial \mathrm{t}_{2}{ }^{\mathrm{mex}} \mathrm{dt}_{2}{ }^{\mathrm{mex}}\right)$

Let us assume that good 1 (exported by Mexico) is labor intensive and good 2 (exported by U.S.) is capital intensive. From expression (3.8) it is obvious that as the U.S. liberalizes, wage rate falls ${ }^{9}$ (i.e $\mathrm{R}_{\mathrm{L} 1}{ }^{\text {us }}>0$ ), hence $\partial \mathrm{I} / \partial \mathrm{t}_{1}{ }^{\mathrm{US}}>0$. Converesely, with liberalization in Mexico the rental rate falls and the wage rises (i.e. $\mathrm{R}_{\mathrm{L} 2}{ }^{{ }^{m e x}}<0$ ), hence $\partial \mathrm{I} / \partial \mathrm{t}_{2}{ }^{\mathrm{mex}}>0$. Consider the expression in (3.11). The first two terms are negative and the second two terms are positive. The net effect on illegal immigration depends on the relative magnitudes of the positive and negative terms.

\subsection{The Empirical Model}

The empirical specification of the model depends on identification of the factors that affect illegal immigration from Mexico to the U.S. We consider the unemployment rate explicitly in the empirical model although, for the sake of simplicity, we do not incorporate it in the theoretical model ${ }^{10}$. We include the average import tariff rates of both nations. If we consider the Heckscher-Ohlin model, then due to trade liberalization

\footnotetext{
${ }^{9}$ This is the finding of Stolper Samuleson Theorem.

${ }^{10}$ Ethier's (1986) theoretical model on illegal immigration deals with unemployment rate. However, our context is different. Hence, we follow a different approach.
} 
the illegal immigration rate should fall as the wage gap between the two countries narrows. However, other possibilities exist if we abstract from the Heckscher-Ohlin framework. We use the minimum wage rate of Mexico and the unskilled wage rate of the U.S. as the wage rates earned by illegal immigrants in the two countries. In the theoretical model we consider both tariffs and foreign direct investments. However, Feenstra and Hanson (1995) note that trade liberalization and foreign investment are highly complementary and their effects cannot be disentangled. Our data also reveals a high correlation ${ }^{11}$ between the tariff rates and foreign direct investment. Hence, we do not consider foreign direct investment in our empirical analysis. GNP growth in Mexico is also an important factor. For example, Bratsberg (1995) argues that a 10\% increase in Mexico's GNP might reduce illegal immigration by $10.3 \%$. Other than these factors, border enforcement plays a vital role in determining the volume of illegal immigration. The number of illegal aliens entering the U.S. depends on how efficient the border patrol is in apprehending them at the border. The effects of border patrol can be captured either by the budget allocated for border patrol or the person-hours spent by the U.S. border patrol policing the border (border patrol hours). We use both measures of border patrol in our analysis (separately) to check the robustness of the effect of tariff liberalization. Hill and Pearce (1990) use the border patrol budget as a measurement of enforcement. On the other hand, Hanson and Spilimbergo (1999b) and Hanson, Robertson, and Spilimbergo (1999) use border patrol hours to measure enforcement. According to White et al. (1990) the efficiency of border enforcement is affected by the budget as well as the number of

\footnotetext{
${ }^{11}$ The correlation coefficient between log of foreign direct investment and log of the ratio between Mexican and the U.S. tariff rate is 0.8 .
} 
personnel available. Immigration policies like the IRCA (1986) and the Immigration Act (1990) are also likely to have some impact on the undocumented labor flow from Mexico. One other important factor is the number of visas issued to Mexican citizens annually. The impact of the number of visas issued could affect illegal immigration in either direction. With increasing visa issuance, the incentive for illegal entry may be reduced. On the other hand, as more people obtain U.S. visas, their relatives might try to cross the border illegally. As additional regressors we use time trend, the Immigration Act dummy (whether the fiscal year 1992 or later) and the IRCA dummy (whether the fiscal year 1987 or later). In additional regressions we use dummies to control for alteration in data collection and reporting procedure by the INS (once in 1977 and then again in 1990). This will control for the possible effect of definitional change.

The total number of illegal immigrants attempting to cross the border at time $t\left(\mathrm{IM}_{\mathrm{t}}\right)$ is expressed as:

$\mathrm{IM}_{\mathrm{t}}=\mathrm{IM}\left((\text { Mexican tariff rate) })_{\mathrm{t}} \text {, (U.S. tariff rate) }\right)_{\mathrm{t}}$ (Mexican unemployment) $)_{t}(\mathrm{U} . \mathrm{S}$. unemployment $)_{t}$, (Mexican per capita GDP) $)_{t}$, Mexican minimum wage $)_{t} /($ U.S. unskilled wage) $t$, (Number of U.S. visas issued to Mexicans) $\left.)_{t}, P_{t}\right)$

where $\mathrm{P}_{\mathrm{t}}$ is the probability of being apprehended while trying to cross the border illegally.

One disadvantage of the empirical analysis is that we do not observe the number of individuals that attempt to cross the border illegally. The number of individuals apprehended by the U.S. border patrol is used as a proxy for the volume of illegal immigrants (Hanson and Spilimbergo, 1999a). Apprehensions at the border $\left(A_{t}\right)$ are a function of the people attempting to cross the border illegally and the probability of being 
apprehended. The probability of being apprehended at the border depends on the budget allocated for the U.S. border patrol (BPbudget $\left.t_{t}\right)$ or border patrol hours (BPhours $)_{t}$. Assuming all individuals face the same apprehension probability, apprehensions at the border can be expressed as:

$\mathrm{A}_{\mathrm{t}}=\mathrm{P}\left(\mathrm{BPbudget}_{\mathrm{t}}\right.$ or BPhours, $\left.\mathrm{IM}_{\mathrm{t}}\right) * \mathrm{IM}($.

A reduced form version of the apprehension function is estimated in the analysis. ${ }^{12}$ Also, the tariff rates of both countries are the average import tariff rates that apply to the entire world (which is equivalent to the MFN tariff rates), not necessarily applicable against each other. Particularly in the case of preferential trading agreement, countries do not apply the MFN tariff rates against each other. To mitigate this problem, a dummy variable for NAFTA is used in the analysis.

\subsection{Data}

The average tariff rates of both countries are calculated by taking the ratio of tariff revenue collected to the total value of imports. Tariff revenues for both countries are available from Government Finance Statistics Yearbook, published by the IMF. Report of the visa office (the U.S. State Department) publishes the number of visas issued to the Mexicans. Mexican population, GNP and value of import data are obtained from International Financial Statistics, IMF. U.S. unskilled wage rates are obtained from unpublished records of the U.S. Department of Agriculture (USDA). An annual dataset is used in the analysis ranging from 1970-1998. Data on apprehensions, border patrol

\footnotetext{
${ }^{12}$ Note $\mathrm{IM}_{\mathrm{t}}$ and $\mathrm{P}_{\mathrm{t}}$ are not observed.
} 
budget and border patrol hours are obtained from unpublished records of the INS. These data are for U.S. linewatch activities that occur at the borders. We use these because it is impossible to find out when people apprehended in the U.S. interior have entered the country.

\subsection{Estimation Results}

While estimating equation (3.13) a $\log$ apprehension function is estimated ${ }^{13}$. Factors affecting apprehensions are also expressed in $\log$ form $^{14}$. Prior to estimation, there are some issues that need to be discussed. First, we note that shocks to apprehensions may be serially correlated. The shock might be an unknown factor that increases the undocumented labor flow into the U.S. To control for serial correlation in shocks, we estimate two specifications of the apprehension function. In the first specification, the disturbance term follows a first order autoregressive $\{\operatorname{AR}(1)\}$ process. In the second specification, we impose the assumption of a unit root in the disturbance term and estimate the apprehension function in first differences ${ }^{15}$. The second issue is related to border enforcement. There is an issue of endogeneity of border patrol budget or border patrol hours where the budget or hours simultaneously get determined with apprehensions. In the U.S., the INS is responsible for protecting the U.S. border and it is constrained by the budget allocation for enforcement. However, the INS has the authority

\footnotetext{
${ }^{13}$ See figure 3.1 for change in log apprehensions.

${ }^{14}$ Figure 3.2, 3.3 and 3.4 show the change in log border patrol budget, change in log border patrol hours and $\log$ U.S tariff and Mexican tariff rates respectively.

${ }^{15}$ The apprehension function does not exhibit nonstationarity.. The augmented Dickey-Fuller test rejects the null hypothesis of a unit root.
} 
to allocate resources appropriately. Therefore, it might increase the resources for the border patrol or increase the number of hours spent in policing the border in response to an increase in the number of people attempting to cross the border illegally. To control for endogeneity of border patrol measures, we use instrumental variable technique. The instruments used are real U.S. government expenditures on national defense and a series of dummies for the occurrence of presidential or congressional election in the current fiscal year (Hanson and Spilimbergo, 1999a).

Estimation results are shown in Table 3.1 through Table 3.7. The first six tables depict ordinary least square (OLS) results in the first column and instrumental variable (IV) results in the second column. Table 3.7 presents the first difference results, where border patrol hours and border patrol budget are used as enforcement measures, in the first and second columns, respectively. It is an annual dataset with the time period for the estimation being 1970 through 1998.

Table 3.1 through Table 3.3 show AR(1) estimation results with border patrol budget used as enforcement measure. The same estimation results with border patrol hours are listed in Table 3.4 to Table 3.6. The estimated coefficient of a regressor can be interpreted as the long run elasticity of border apprehensions with respect to that regressor. The tables show that the elasticity of apprehensions with respect to border patrol budget or border patrol hours is positive. However, border patrol budget and border patrol hours turn out to be insignificant in all regressions. This is not surprising, since often in reality illegal workers are welcome in the U.S. because they provide cheap labor. Hanson and 
Spilimbergo (1999b) note that growers in California and Texas often declare that without low-wage foreign labor they would be forced to cut back production or completely shut down their operations. In favor of hiring illegal immigrants a California grower said. "The reality is that if the government was able to stop everybody at the border, there would be no agriculture. You wouldn't be eating asparagus" (Walsh, 1999). Calavita (1992, p. 35) documents a Texas grower remarking, "For a number of years citizens of Mexico entered the United States both legally and illegally, engaging in agricultural work. While from time to time they have been picked up by the Border Patrol, there has been a tendency on part of the Border Patrol to concentrate their efforts on deporting only those who are bad citizens. This arrangement, although it did not have the stamp of legislative approval, has worked out very nicely for our farmers down here."

Results reveal that current and lagged Mexican tariff rates have positive and statistically significant correlation with apprehension. This implies that as Mexico liberalizes, the flow of undocumented labor decreases. This is consistent with the finding of the Heckscher-Ohlin model. The current U.S. tariff rate appears to be insignificant in all regressions. However, the lagged U.S. tariff rate is significantly negative in some regressions. This implies that past U.S liberalization will provide a positive drive to illegal labor flow. However the ratio between Mexican and the U.S. wage rate is insignificant. This can be explained by the Heckscher-Ohlin theorem. According to this theory as a consequence of trade liberalization the wage difference between Mexico and the U.S. will reduce. Based on this we can argue that since the tariff rate influences wage rate, the impact of the wages become insignificant in the regression while tariff rates 
capture the entire impact. The ratio between the unemployment rates of Mexico and the U.S. is also significant and positive. Obviously, higher unemployment in Mexico will exert an upward pressure on the unskilled labor force to emigrate illegally. NAFTA and IRCA dummies turn out to be significantly negative. The introduction of NAFTA and IRCA seems to reduce the flow of illegal immigrants. Even though many economists are not too optimistic about the effects of NAFTA in the short run, we find that even in the short run its introduction reduces illegal immigration. The IRCA finding is consistent with Bean et al (1990) for their analysis between 1977 and 1989. The dummy variable for the passage of the Immigration Act does not have any significant effect on illegal immigration except for Table 3.6, where enforcement is measured by border patrol hours. Immigration Act has a significantly negative effect on illegal immigration for this particular specification. In Table 3.5 and Table 3.6, visas issued to Mexicans exhibit significantly negative impact on illegal immigration. This implies a lower incentive for immigrants to cross the border illegally with the issuance of larger number of visas. The results for the first difference model in Table 3.7 emphasize the role of Mexican per capita GDP. We find that it affects illegal immigrants negatively. As expected the flow of illegal immigrants from Mexico should reduce with the increase in Mexican per capita GDP.

\subsection{Conclusion}

This essay examines the determinants of illegal immigration between the U.S. and Mexico. We first provide a theoretical model and then an empirical analysis. The novelty of the analysis is to incorporate tariff rates as a determinant of illegal immigration. The 
Mexican tariff rates appear to have a significant effect on illegal immigration. We find that as Mexico pursues trade liberalization policies, the flow of illegal immigration from Mexico to the U.S. falls. This result is consistent with the Heckscher-Ohlin model. It is robust to the choice of border patrol measure and the specification of the model. However, border patrol measures do not appear to have significant effects on apprehension. The finding is very interesting, because it suggests that trade policy may be a more effective tool in controlling illegal immigration compared to immigration policy. 


\section{Table 3.1: First AR(1) Specification of Border Apprehension with}

Border Patrol Budget as Enforcement Measure

\begin{tabular}{|lll|}
\hline & OLS1 & IV1 \\
\hline Constant & 9.88 & 12.01 \\
\hline & $(6.17)$ & $(8.67)$ \\
\hline Log Border Patrol Budget & 0.28 & 0.17 \\
\hline & $(0.33)$ & $(0.45)$ \\
\hline Log Mexican Tariff Rate & $0.30^{* *}$ & $0.29^{* *}$ \\
\hline & $(0.10)$ & $(0.11)$ \\
\hline Log U.S. Tariff Rate & -0.25 & -0.27 \\
\hline & $(0.19)$ & $(0.19)$ \\
\hline Log of ratio between Mexican and U.S. unskilled wage & 0.26 & 0.27 \\
\hline & $(0.30)$ & $(0.31)$ \\
\hline Log of ratio between Mexican and U.S. unemployment & $0.45^{* * *}$ & $0.43^{* * *}$ \\
\hline & $(0.11)$ & $(0.12)$ \\
\hline Log of Mexican per capita GDP & -0.49 & -0.50 \\
\hline & $(0.33)$ & $(0.34)$ \\
\hline Log of visas issued to Mexicans & -0.10 & -0.11 \\
\hline & $(0.13)$ & $(0.15)$ \\
\hline NAFTA & $-0.33^{* * *}$ & $-0.33^{* *}$ \\
\hline & $(0.11)$ & $(0.11)$ \\
\hline Immigration Act & 0.01 & 0.01 \\
\hline & $(0.10)$ & $(0.11)$ \\
\hline IRCA & $-0.45^{* * *}$ & $-0.44^{* * *}$ \\
\hline & $(0.11)$ & $(0.12)$ \\
\hline AR(1) & $0.78^{* * *}$ & $0.77^{* * *}$ \\
\hline & $(0.08)$ & $(0.08)$ \\
\hline Time & 0.09 & $0.10^{*}$ \\
\hline Number of observations & $(0.05)$ & $(0.05)$ \\
\hline Adjusted R-squared & 28 & 28 \\
\hline Durbin-Watson statistic & 0.98 & 0.98 \\
\hline & 2.09 & 2.02 \\
\hline & & \\
\hline & & \\
\hline & & \\
\hline & & \\
\hline
\end{tabular}

Note:

1. $*, * *, * * *$ imply significance at $10 \%, 5 \%$ and $1 \%$ level of significance respectively under a two -tailed test

2. Standard errors are listed inside parentheses. 


\section{Table 3.2: Second AR(1) Specification of Border Apprehension with Border Patrol Budget as Enforcement Measure}

\begin{tabular}{|c|c|c|}
\hline & OLS2 & IV2 \\
\hline \multirow[t]{2}{*}{ Constant } & 4.03 & 9.10 \\
\hline & $(6.00)$ & $(8.51)$ \\
\hline \multirow[t]{2}{*}{ Log of Border Patrol Budget } & 0.62 & 0.34 \\
\hline & $(0.32)$ & $(0.44)$ \\
\hline \multirow[t]{2}{*}{ Log of Mexican Tariff Rate } & $0.40^{* * *}$ & $0.40 * * *$ \\
\hline & $(0.09)$ & $(0.10)$ \\
\hline \multirow[t]{2}{*}{ Log of Mexican Tariff Rate $(-1)$} & $0.23 * *$ & $0.21 *$ \\
\hline & $(0.08)$ & $(0.10)$ \\
\hline \multirow[t]{2}{*}{ Log of U.S. Tariff Rate } & -0.14 & -0.19 \\
\hline & $(0.17)$ & $(0.19)$ \\
\hline \multirow[t]{2}{*}{ Log of U.S. Tariff Rate $(-1)$} & $-0.39 * *$ & $-0.39 * *$ \\
\hline & $(0.17)$ & $(0.18)$ \\
\hline \multirow[t]{2}{*}{ Log of ratio between Mexican and U.S. unskilled wage } & 0.05 & 0.13 \\
\hline & $(0.28)$ & $(0.29)$ \\
\hline \multirow[t]{2}{*}{ Log of ratio between Mexican and U.S. unemployment } & $0.66 * * *$ & $0.61 * * *$ \\
\hline & $(0.11)$ & $(0.15)$ \\
\hline \multirow[t]{2}{*}{ Log of Mexican per capita GDP } & -0.24 & -0.34 \\
\hline & $(0.30)$ & $(0.31)$ \\
\hline \multirow[t]{2}{*}{ Log of visas issued to Mexicans } & -0.17 & -0.18 \\
\hline & $(0.10)$ & $(0.11)$ \\
\hline \multirow[t]{2}{*}{ NAFTA } & $-0.31 * * *$ & $-0.33 * * *$ \\
\hline & $(0.09)$ & $(0.09)$ \\
\hline \multirow[t]{2}{*}{ Immigration Act } & -0.09 & -0.09 \\
\hline & $(0.09)$ & $(0.10)$ \\
\hline \multirow[t]{2}{*}{ IRCA } & $-0.53 * * *$ & $-0.49 * * *$ \\
\hline & $(0.10)$ & $(0.12)$ \\
\hline \multirow[t]{2}{*}{ Time } & 0.06 & $0.10^{*}$ \\
\hline & $(0.06)$ & $(0.06)$ \\
\hline \multirow[t]{2}{*}{$\mathrm{AR}(1)$} & $0.82 * * *$ & $0.78 * * *$ \\
\hline & $(0.09)$ & $(0.09)$ \\
\hline Number of observations & 27 & 27 \\
\hline Adjusted R-squared & 0.98 & 0.98 \\
\hline Durbin-Watson statistic & 2.48 & 2.35 \\
\hline
\end{tabular}

Note:

1. $*, * *, * * *$ imply significance at $10 \%, 5 \%$ and $1 \%$ level of significance respectively under a two -tailed test

2. Standard errors are listed inside parentheses. 
Table 3.3: Third AR(1) Specification of Border Apprehension with Border Patrol Budget as Enforcement Measure

\begin{tabular}{|c|c|c|}
\hline & OLS3 & IV3 \\
\hline \multirow[t]{2}{*}{ Constant } & 4.02 & 7.76 \\
\hline & $(6.52)$ & $(9.44)$ \\
\hline \multirow[t]{2}{*}{ Log of Border Patrol Budget } & 0.66 & 0.44 \\
\hline & $(0.39)$ & $(0.54)$ \\
\hline \multirow[t]{2}{*}{ Log of Mexican Tariff Rate } & $0.38 * * *$ & $0.38 * * *$ \\
\hline & $(0.10)$ & $(0.11)$ \\
\hline \multirow[t]{2}{*}{ Log of Mexican Tariff Rate (-1) } & $0.22 * *$ & $0.20 * *$ \\
\hline & $(0.10)$ & $(0.10)$ \\
\hline \multirow[t]{2}{*}{ Log of U.S. Tariff Rate } & -0.20 & -0.21 \\
\hline & $(0.22)$ & $(0.24)$ \\
\hline \multirow[t]{2}{*}{ Log of U.S. Tariff Rate (-1) } & $-0.37 *$ & $-0.38 *$ \\
\hline & $(0.19)$ & $(0.20)$ \\
\hline \multirow[t]{2}{*}{ Log of ratio between Mexican and U.S. unskilled wage } & 0.13 & 0.15 \\
\hline & $(0.33)$ & $(0.35)$ \\
\hline \multirow[t]{2}{*}{ Log of ratio between Mexican and U.S. unemployment } & $0.65^{* * *}$ & $0.62 * * *$ \\
\hline & $(0.13)$ & $(0.16)$ \\
\hline \multirow[t]{2}{*}{ Log of Mexican per capita GDP } & -0.33 & -0.36 \\
\hline & $(0.37)$ & $(0.38)$ \\
\hline \multirow[t]{2}{*}{ Log of visas issued to Mexicans } & -0.16 & -0.18 \\
\hline & $(0.12)$ & $(0.13)$ \\
\hline \multirow[t]{2}{*}{ NAFTA } & $-0.30 * *$ & $-0.32 * * *$ \\
\hline & $(0.10)$ & $(0.10)$ \\
\hline \multirow[t]{2}{*}{ Immigration Act } & -0.07 & -0.07 \\
\hline & $(0.10)$ & $(0.11)$ \\
\hline \multirow[t]{2}{*}{ IRCA } & $-0.53 * * *$ & $-0.49 * * *$ \\
\hline & $(0.11)$ & $(0.12)$ \\
\hline \multirow[t]{2}{*}{ D1 } & -0.07 & -0.05 \\
\hline & $(0.14)$ & $(0.15)$ \\
\hline \multirow[t]{2}{*}{ D2 } & 0.03 & 0.03 \\
\hline & $(0.12)$ & $(0.14)$ \\
\hline \multirow[t]{2}{*}{ Time } & 0.04 & 0.08 \\
\hline & $(0.09)$ & $(0.09)$ \\
\hline \multirow[t]{2}{*}{$\mathrm{AR}(1)$} & $0.86^{* * *}$ & $0.82 * * *$ \\
\hline & $(0.11)$ & $(0.13)$ \\
\hline Number of observations & 27 & 27 \\
\hline Adjusted R-squared & 0.98 & 0.98 \\
\hline Durbin-Watson statistic & 2.39 & 2.31 \\
\hline
\end{tabular}

Note: $1 .{ }^{*},{ }^{* *},{ }^{* * *}$ imply significance at $10 \%, 5 \%$ and $1 \%$ level of significance respectively under a twotailed test

2. Standard errors are listed inside parentheses.

3. D1 is the dummy to control for any definitional change that may have occurred in 1977.

4. D2 is the dummy to control for any definitional change that may have occurred in 1990. 


\section{Table 3.4: Fourth AR(1) Specification of Border Apprehension with Border Patrol Hours as Enforcement Measure}

\begin{tabular}{|c|c|c|}
\hline & OLS4 & IV4 \\
\hline \multirow[t]{2}{*}{ Constant } & $12.92 * * *$ & $10.96 * *$ \\
\hline & $(3.00)$ & $(3.85)$ \\
\hline \multirow[t]{2}{*}{ Log of Border Patrol Hours } & 0.15 & 0.29 \\
\hline & $(0.18)$ & $(0.25)$ \\
\hline \multirow[t]{2}{*}{ Log of Mexican Tariff Rate } & $0.26^{* *}$ & $0.22 *$ \\
\hline & $(0.11)$ & $(0.11)$ \\
\hline \multirow[t]{2}{*}{ Log of U.S. Tariff Rate } & -0.25 & -0.21 \\
\hline & $(0.19)$ & $(0.20)$ \\
\hline \multirow[t]{2}{*}{ Log of ratio between Mexican and U.S. unskilled wage } & 0.21 & 0.15 \\
\hline & $(0.32)$ & $(0.32)$ \\
\hline \multirow[t]{2}{*}{ Log of ratio between Mexican and U.S. unemployment rate } & $0.40 * * *$ & $0.38 * *$ \\
\hline & $(0.10)$ & $(0.10)$ \\
\hline \multirow[t]{2}{*}{ Log of Mexican per capita GDP } & -0.42 & -0.34 \\
\hline & $(0.35)$ & $(0.34)$ \\
\hline \multirow[t]{2}{*}{ Log of visas issued to Mexicans } & -0.13 & -0.13 \\
\hline & $(0.12)$ & $(0.12)$ \\
\hline \multirow[t]{2}{*}{ NAFTA } & $-0.33 * * *$ & $-0.33^{* *}$ \\
\hline & $(0.11)$ & $(0.11)$ \\
\hline \multirow[t]{2}{*}{ Immigration Act } & 0.02 & 0.03 \\
\hline & $(0.11)$ & $(0.11)$ \\
\hline \multirow[t]{2}{*}{ IRCA } & $-0.40 * * *$ & $-0.38 * * *$ \\
\hline & $(0.11)$ & $(0.12)$ \\
\hline \multirow[t]{2}{*}{$\operatorname{AR}(1)$} & $0.77 * * *$ & $0.79 * * *$ \\
\hline & $(0.08)$ & $(0.08)$ \\
\hline \multirow[t]{2}{*}{ Time } & $0.11^{* *}$ & $0.09 * *$ \\
\hline & $(0.04)$ & $(0.04)$ \\
\hline Number of observations & 28 & 28 \\
\hline Adjusted R-squared & 0.98 & 0.98 \\
\hline Durbin-Watson statistic & 2.14 & 2.29 \\
\hline
\end{tabular}

Note:

1. $*, * *, * * *$ imply significance at $10 \%, 5 \%$ and $1 \%$ level of significance respectively under a two -tailed test

2. Standard errors are listed inside parentheses. 
Table 3.5: Fifth AR(1) Specification of Border Apprehension with Border Patrol Hours as Enforcement Measure

\begin{tabular}{|c|c|c|}
\hline & OLS5 & IV5 \\
\hline \multirow[t]{2}{*}{ Constant } & $13.02 * * *$ & $12.48^{* *}$ \\
\hline & $(3.54)$ & $(4.16)$ \\
\hline \multirow[t]{2}{*}{ Log of Border Patrol Hours } & 0.16 & 0.19 \\
\hline & $(0.19)$ & $(0.23)$ \\
\hline \multirow[t]{2}{*}{ Log of Mexican Tariff Rate } & $0.33 * *$ & $0.33 * *$ \\
\hline & $(0.12)$ & $(0.12)$ \\
\hline \multirow[t]{2}{*}{ Log of Mexican Tariff Rate (-1) } & $0.18 *$ & $0.18^{*}$ \\
\hline & $(0.08)$ & $(0.09)$ \\
\hline \multirow[t]{2}{*}{ Log of US Tariff Rate } & -0.19 & -0.18 \\
\hline & $(0.21)$ & $(0.21)$ \\
\hline \multirow[t]{2}{*}{ Log of U.S. Tariff Rate (-1) } & -0.33 & -0.32 \\
\hline & $(0.20)$ & $(0.20)$ \\
\hline \multirow[t]{2}{*}{ Log of ratio between Mexican and U.S. unskilled wage } & 0.07 & 0.06 \\
\hline & $(0.34)$ & $(0.35)$ \\
\hline \multirow[t]{2}{*}{ Log of ratio between Mexican and U.S. unemployment rate } & $0.52 * * *$ & $0.52 * * *$ \\
\hline & $(0.11)$ & $(0.11)$ \\
\hline \multirow[t]{2}{*}{ Log of Mexican per capita GDP } & -0.26 & -0.24 \\
\hline & $(0.38)$ & $(0.39)$ \\
\hline \multirow[t]{2}{*}{ Log of visas issued to Mexicans } & $-0.21 *$ & $-0.21 *$ \\
\hline & $(0.12)$ & $(0.12)$ \\
\hline \multirow[t]{2}{*}{ NAFTA } & $-0.33 * * *$ & $-0.33 * * *$ \\
\hline & $(0.10)$ & $(0.10)$ \\
\hline \multirow[t]{2}{*}{ Immigration Act } & -0.07 & -0.07 \\
\hline & $(0.10)$ & $(0.10)$ \\
\hline \multirow[t]{2}{*}{ IRCA } & $-0.42 * * *$ & $-0.42 * * *$ \\
\hline & $(0.10)$ & $(0.10)$ \\
\hline \multirow[t]{2}{*}{ Time } & $0.12 * * *$ & $0.12 * * *$ \\
\hline & $(0.04)$ & $(0.04)$ \\
\hline \multirow[t]{2}{*}{$\mathrm{AR}(1)$} & $0.76^{* * *}$ & $0.76^{* * *}$ \\
\hline & $(0.10)$ & $(0.10)$ \\
\hline Number of observations & 27 & 27 \\
\hline Adjusted R-squared & 0.98 & 0.98 \\
\hline Durbin-Watson stat & 2.35 & 2.41 \\
\hline
\end{tabular}

Note:

1. *, **,*** imply significance at $10 \%, 5 \%$ and $1 \%$ level of significance respectively under a two -tailed test

2. Standard errors are listed inside parentheses. 
Table 3.6: Sixth AR(1) Specification of Border Apprehension with Border Patrol Hours as Enforcement Measure

\begin{tabular}{|c|c|c|}
\hline & OLS6 & IV6 \\
\hline \multirow[t]{2}{*}{ Constant } & $18.05^{* * *}$ & $18.21 * * *$ \\
\hline & $(4.70)$ & $(5.72)$ \\
\hline \multirow[t]{2}{*}{ Log of Border Patrol Hours } & 0.07 & 0.07 \\
\hline & $(0.21)$ & $(0.26)$ \\
\hline \multirow[t]{2}{*}{ Log of Mexican Tariff Rate } & $0.34 *$ & $0.34 *$ \\
\hline & $(0.16)$ & $(0.16)$ \\
\hline \multirow[t]{2}{*}{ Log of Mexican Tariff Rate (-1) } & 0.34 & $0.34 *$ \\
\hline & $(0.19)$ & $(0.18)$ \\
\hline \multirow[t]{2}{*}{ Log of U.S. Tariff Rate } & -0.32 & -0.32 \\
\hline & $(0.23)$ & $(0.24)$ \\
\hline \multirow[t]{2}{*}{ Log of U.S. Tariff Rate (-1) } & $-1.04 * * *$ & $-1.04 * * *$ \\
\hline & $(0.26)$ & $(0.27)$ \\
\hline \multirow[t]{2}{*}{ Log of ratio between Mexican and U.S. unskilled wage } & 0.81 & 0.82 \\
\hline & $(0.38)$ & $(0.39)$ \\
\hline \multirow[t]{2}{*}{ Log of ratio between Mexican and U.S. unemployment rate } & $0.67 * *$ & $0.67 * *$ \\
\hline & $(0.25)$ & $(0.23)$ \\
\hline \multirow[t]{2}{*}{ Log of Mexican per capita GDP } & -0.75 & -0.76 \\
\hline & $(0.48)$ & $(0.48)$ \\
\hline \multirow[t]{2}{*}{ Log of visas issued to Mexicans } & $-0.44 *$ & $-0.44^{*}$ \\
\hline & $(0.20)$ & $(0.21)$ \\
\hline \multirow[t]{2}{*}{ NAFTA } & $-0.59 * *$ & $-0.59 * *$ \\
\hline & $(0.25)$ & $(0.22)$ \\
\hline \multirow[t]{2}{*}{ Time } & $0.21^{* * *}$ & $0.21^{* * *}$ \\
\hline & $(0.04)$ & $(0.04)$ \\
\hline \multirow[t]{2}{*}{ Immigration Act } & $-0.41^{*}$ & $-0.41^{*}$ \\
\hline & $(0.20)$ & $(0.20)$ \\
\hline \multirow[t]{2}{*}{ IRCA } & $-0.50 * * *$ & $-0.50 * * *$ \\
\hline & $(0.11)$ & $(0.11)$ \\
\hline \multirow[t]{2}{*}{$\mathrm{D} 1$} & 0.16 & 0.16 \\
\hline & $(0.11)$ & $(0.10)$ \\
\hline \multirow[t]{2}{*}{$\mathrm{D} 2$} & 0.06 & 0.06 \\
\hline & $(0.21)$ & $(0.21)$ \\
\hline \multirow[t]{2}{*}{$\mathrm{AR}(1)$} & 0.58 & 0.57 \\
\hline & $(0.39)$ & $(0.34)$ \\
\hline Number of observations & 27 & 27 \\
\hline Adjusted R-squared & 0.97 & 0.97 \\
\hline Durbin-Watson statistic & 2.62 & 2.62 \\
\hline
\end{tabular}

Note: $1 .{ }^{*},{ }^{* *},{ }^{* * *}$ imply significance at $10 \%, 5 \%$ and $1 \%$ level of significance respectively under a two tailed test

2. Standard errors are listed inside parentheses.

3. D1 is the dummy to control for any definitional change that may have occurred in 1977.

4. D2 is the dummy to control for any definitional change that may have occurred in 1990. 
Table 3.7: First Difference Specification of Border Apprehension

\begin{tabular}{|lll|}
\hline & OLS7 & OLS8 \\
\hline Constant & 0.18 & $0.16^{* *}$ \\
\hline Difference in log of Border Patrol Budget & $(0.05)$ & $(0.06)$ \\
\hline & & 0.19 \\
\hline Difference in log of Border Patrol Hours & & $(0.42)$ \\
\hline & 0.04 & \\
\hline Difference in log of Mexican Tariff Rate & $(0.25)$ & \\
\hline & $0.26^{*}$ & $0.26^{*}$ \\
\hline Difference in log of U.S. Tariff Rate & $(0.15)$ & $(0.13)$ \\
\hline & -0.36 & $-0.41^{*}$ \\
\hline Difference in log of ratio between Mexican and U.S. unskilled wage & $(0.22)$ & $(0.24)$ \\
\hline & 0.61 & 0.58 \\
\hline Difference in log of ration between Mexican and U.S. unemploymenent & $(0.37)$ & $(0.37)$ \\
\hline & $0.35^{* *}$ & $0.40^{* * *}$ \\
\hline Difference in log of Mexican per capita GDP & $(0.13)$ & $(0.14)$ \\
\hline & $-0.72^{*}$ & $-0.77^{*}$ \\
\hline Difference in the number of visas issued to Mexicans & $(0.38)$ & $(0.41)$ \\
\hline & -0.20 & -0.11 \\
\hline Difference in NAFTA & $(0.15)$ & $(0.16)$ \\
\hline & $-0.38^{* *}$ & $-0.39^{* *}$ \\
\hline Difference in Immigration Act & $(0.13)$ & $(0.14)$ \\
\hline & -0.06 & -0.03 \\
\hline Difference in IRCA & $(0.14)$ & $(0.13)$ \\
\hline & $-0.44^{* * *}$ & $-0.45^{* * *}$ \\
\hline Number of observations & $(0.13)$ & $(0.15)$ \\
\hline Adjusted R-squared & 28 & 28 \\
\hline Durbin-Watson statistic & 0.55 & 0.53 \\
\hline & 1.62 & 1.45 \\
\hline & & \\
\hline & & \\
\hline & & \\
\hline & & \\
\hline & & \\
\hline
\end{tabular}

Note:

1. *, $* *, * * *$ imply significance at $10 \%, 5 \%$ and $1 \%$ level of significance respectively under a two -tailed test

2. Standard errors are listed inside parentheses. 
Table 3.8: Descriptive statistics of the variables

\begin{tabular}{|l|l|l|l|l|l|}
\hline Variable & Mean & Median & Std. Dev. & Min & Max \\
\hline $\begin{array}{l}\text { Number of } \\
\text { Apprehensions }\end{array}$ & 591214 & 592432 & 304013 & 79702 & 1224740 \\
\hline $\begin{array}{l}\text { Number of Border patrol } \\
\text { hours }\end{array}$ & 2564161 & 2148202 & 1371672 & 1044147 & 7604083 \\
\hline $\begin{array}{l}\text { Border patrol budget } \\
\text { (in U.S. \$) }\end{array}$ & $2.12 \mathrm{e}+08$ & $1.14 \mathrm{e}+08$ & $2.14 \mathrm{e}+08$ & $2.84 \mathrm{e}+07$ & $8.75 \mathrm{e}+08$ \\
\hline $\begin{array}{l}\text { Mexican tariff rate } \\
\text { (in percentage) }\end{array}$ & 9.62 & 7.14 & 6.98 & 1.87 & 28.14 \\
\hline $\begin{array}{l}\text { U.S. tariff rate } \\
\text { (in percentage) }\end{array}$ & 3.74 & 3.48 & 1.20 & 2.02 & 7.02 \\
\hline
\end{tabular}


Figure 3.1: Change in log apprehensions over time

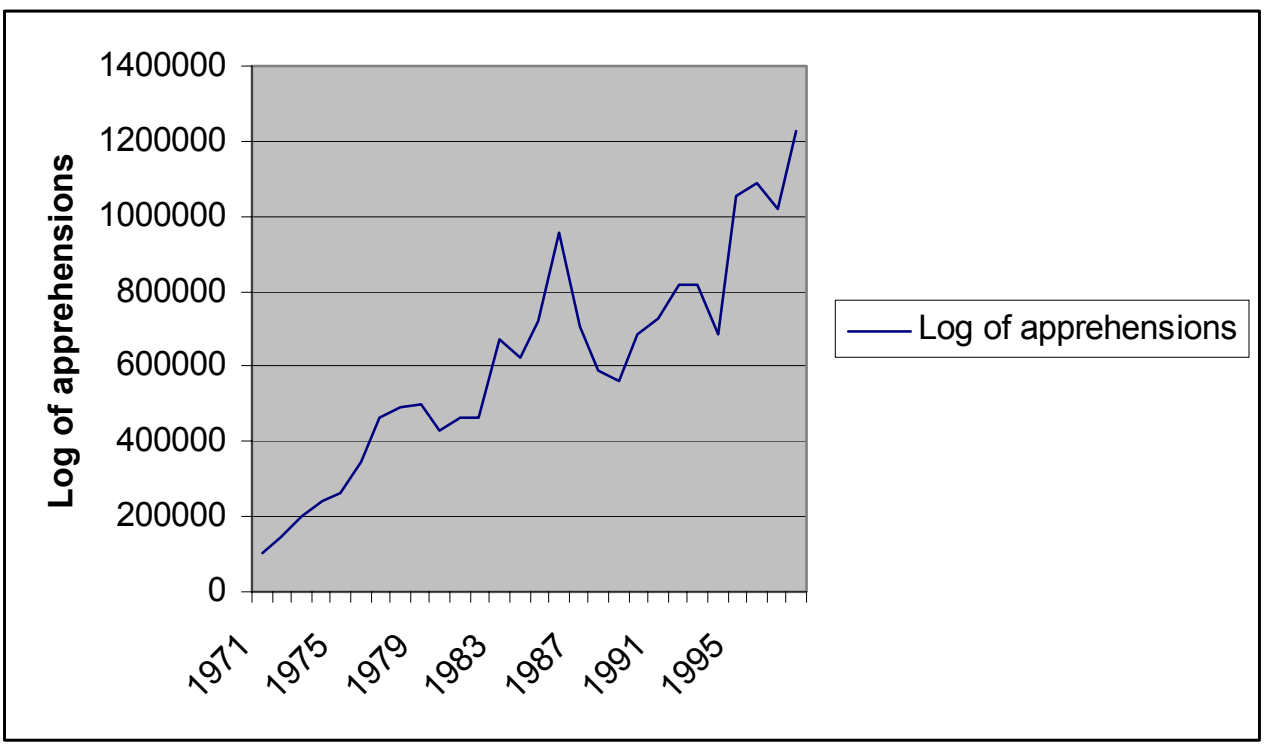

Figure 3.2: Change in log border patrol budget over time

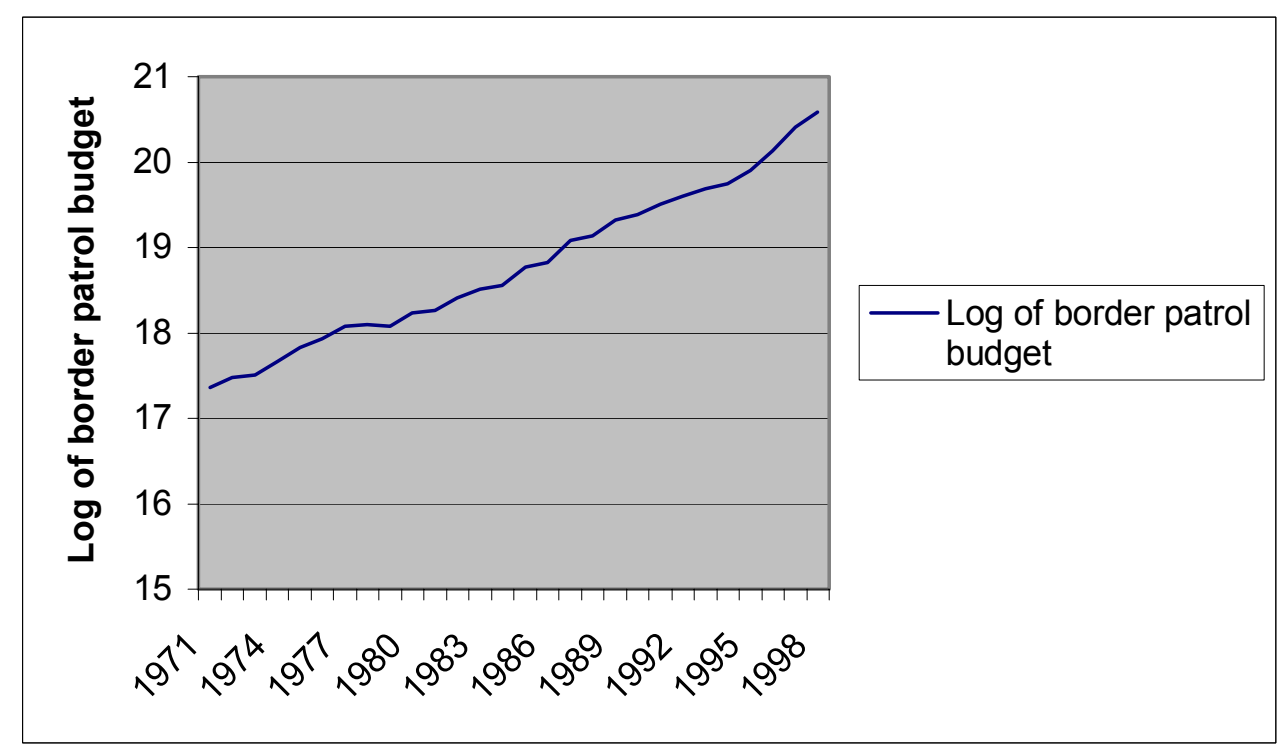


Figure 3.3: Change in log border patrol hours over time

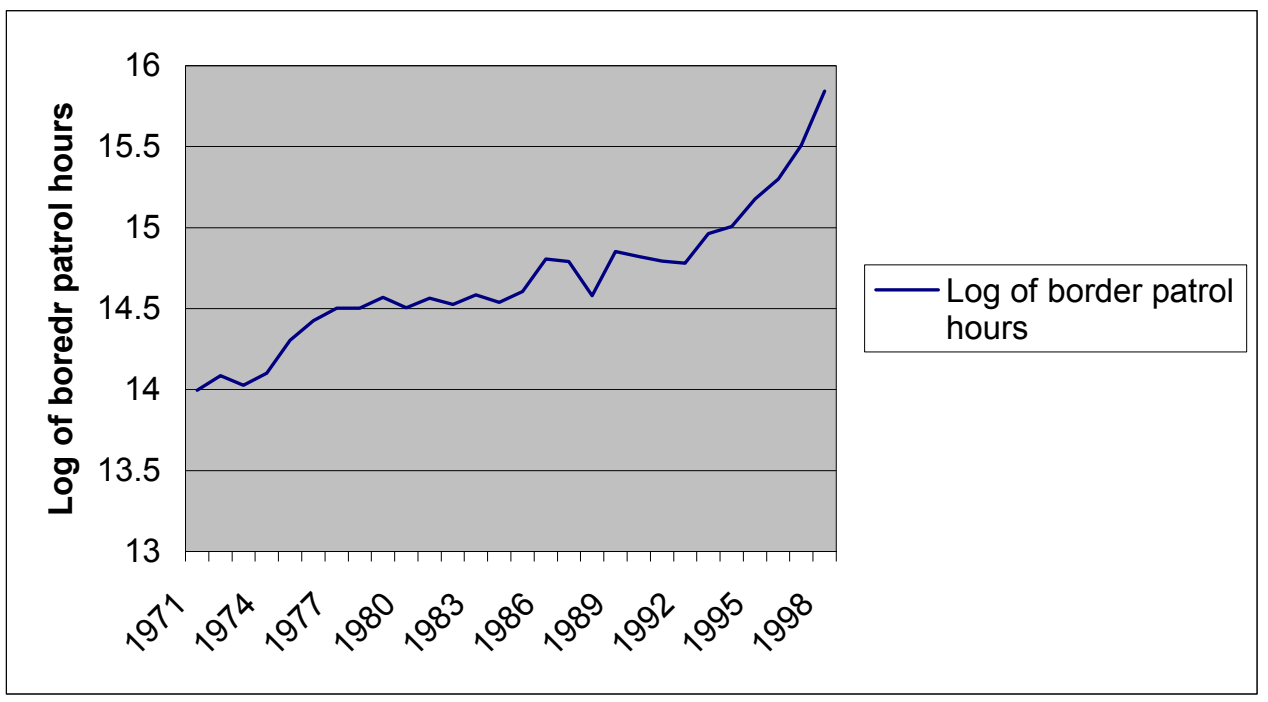

Figure 3.4: Change in Log Mexican and Log U.S. tariff rates over time

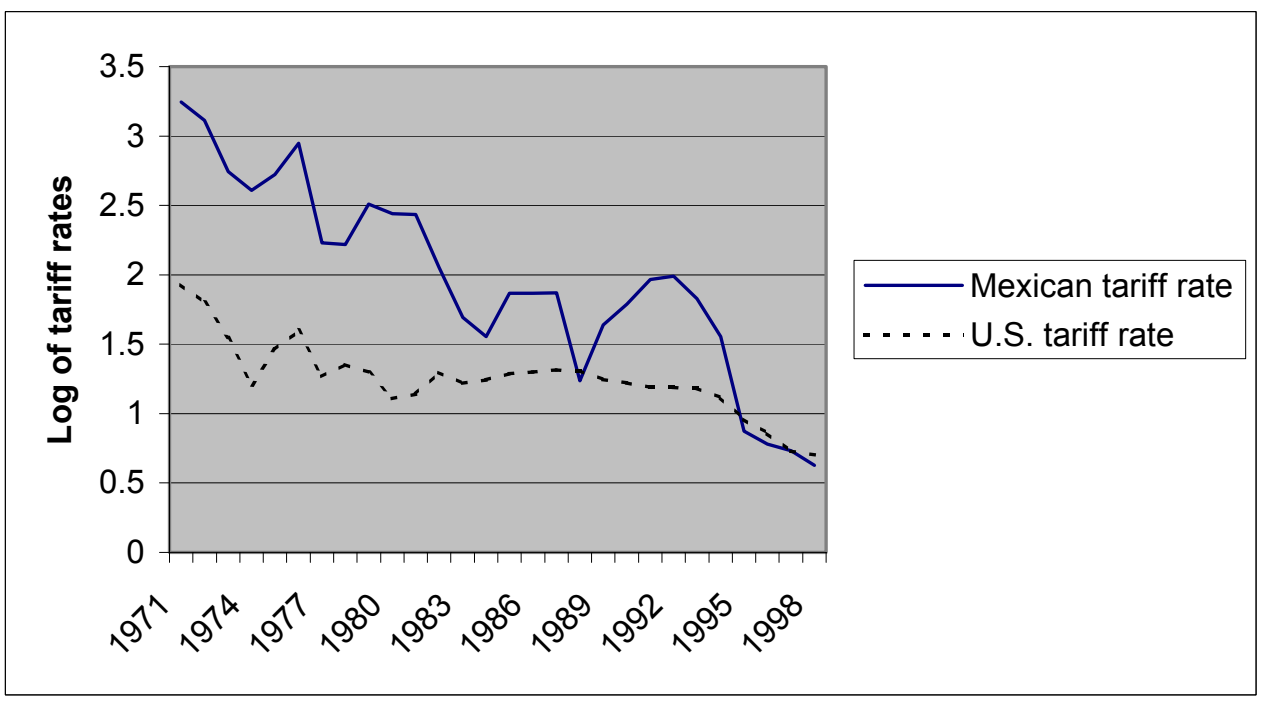




\section{Chapter 4}

\section{Trade Liberalization and Legal Immigration}

\subsection{Introduction}

Recent immigration literature and immigration policy discussions have mostly focused on the increasing number of illegal immigrants to the U.S. However, legal immigration to the United States has surged over the past few decades. Between 1971 and 1998 the number of legal immigrants soared from 370,478 to 643,025 (INS statistical yearbook). There is increasing concern that domestic workers may face reduced employment opportunities and wages due to soaring immigration. On the other hand, others have suggested that legal immigrants may be used to meet labor shortages in the U.S. In 1988 the Secretary of Labor argued, "the U.S. economy cannot endure long term, large scale disruptions caused by lack of a competent work-force, domestic or foreign" (U.S. Government Printing Office [GPO] 1988). Admitting more legal immigrants, a large portion of which are skilled, can be viewed as a way to achieve competitiveness.

This study attempts to link legal migration to the U.S. to trade liberalization. In the migration literature, several studies have demonstrated linkage between trade liberalization and immigration. A CEPR study (1992) finds that a movement towards a relatively liberal trade regime between the EU and the Central and Eastern European countries (CEEC) reduces immigration from the CEEC to the EU. Similarly, Zimmermann (1993) argues that migration pressure from the East and South can be 
reduced by exporting capital and liberalizing trade. However, Lopez and Schiff (1995) conclude that migration of skilled workers is unaffected by trade liberalization in a developing country with a stable population.

Migration theory was first built upon the push-pull formulation of Ravenstein (1889). Migration occurs from areas of low opportunity to areas of high opportunity. In the past few decades not only has the volume of immigration increased, the demographic composition of immigration has also changed. This provides the basis for studying the flow of legal immigration from various countries that have contributed significantly to the high volume of legal immigration to the U.S. in the past. The source countries (where the legal immigration originates) in our sample are: India, El Salvador, Korea, Mexico, the Philippines, the United Kingdom, and Canada; and the host country (i.e. the destination of the immigrants) is the United States. The objective is to study the impact of trade liberalization in the origin countries on legal immigration to the United States. The sample period ranges from 1980 to 1998 .

The paper is organized in the following sections. Section 4.2 discusses the definition of legal immigration and related concepts, and also the changes in immigration laws. Section 4.3. is about trade liberalization as experienced by the countries in our sample. Section 4.4 discusses the push-pull theory of immigration that relates to this study. Section 4.5 describes the empirical model, Section 4.6 discusses the data, Section 4.7 presents the estimation results, and Section 4.8 concludes the paper. 


\subsection{Legal Immigration, Immigration Laws and Related Basic Concepts}

Prior to examining the impact of trade liberalization on legal immigration, it is important to understand what exactly "legal immigration" means. Legal immigration consists of immigrants and nonimmigrants. Immigrants are citizens of other countries, who have been granted visas allowing them to live and work permanently in the United States. Nonimmigrants are granted temporary entry into the U.S. for a specific purpose, such as to visit, work, or study. We are interested in the impact of liberalization only on the immigrants. Immigrants are the people who decide to migrate depending on the availability and relative attractiveness of job opportunities in their home and foreign countries. Clearly, these incentives are affected by trade liberalization. Immigrants not only include people immigrating permanently from their home countries but also those nonimmigrants in the U.S. who have been granted immigrant status.

The most important concept in the immigration literature that is relevant for our study is how we measure legal immigration. The objective is to filter the skilled legal immigrants from the total volume of legal immigrants. This leads us to focus on the immigrants admitted under employment-based preference and family-based preference. ${ }^{16}$ These two categories admit the maximum number of skilled legal immigrants. However, the entire population of family-sponsored immigrants may not be skilled immigrants. To determine the exact number of skilled immigrants in the entire population of family sponsored immigrants is beyond our scope. Hence, we measure the number of skilled legal

\footnotetext{
${ }^{16}$ The preference system decides the priority of the immigrants and permits entry based on their priority. It allots certain number of immigrant visas for each preference category.
} 
immigrants by the total annual volume of employment-based and family-based immigrants.

In this context, it is useful to discuss the U.S. Immigration Act, which has made it possible for immigrants to gain entrance into the U.S. An understanding of the various paths of admission and how these have changed over time provides an important framework for examining the impact on immigrants. While immigration laws have evolved over several centuries, we will focus on the changes that have occurred recently. The changes in immigration laws that occurred between 1980 and 1998 are the Refugee Act of 1980, the Immigration and Reform Control Act of 1986, and the Immigration Act of 1990 (Sorensen et al., 1992).

In the 1980s Congress passed two important laws relating to immigrants and refugees. The Refugee Act of 1980 changed the preference system of the immigrants and established a separate admission process for them. The Immigration and Reform Control Act of 1986 was targeted to control illegal immigration. The objective of this program was to (1) impose sanctions on employers hiring illegal immigrants and (2) offer opportunity to illegal immigrants who had stayed in the U.S. for at least five years or who had worked in agriculture for a specified period of time to adjust to legal resident status. Obviously, this had implications for the number of legal immigrants.

The Immigration Act of 1990, which was implemented in FY 1992, had a far-reaching effect on legal immigrants. The Immigration Act of 1990 modified the immigrant 
categories of admission. It divided the preference class into two broad categories: familysponsored and independent immigration. The act specified that the family-sponsored limit might not go below a minimum of 226,000. The independent immigration category includes employment-based immigration and diversity immigration. The 1990 Immigration Act set the worldwide limit on employment-based preference immigration at 140,000 plus unused family-preference visas in the previous year. The diversity immigration includes people that replaced the earlier categories for nationals of underrepresented countries and countries adversely affected by the Immigration and Nationality Act Amendments of 1965. The annual limit on diversity immigration was set at 40,000 for FY 1992-1994 under a transitional diversity program, and, beginning in FY 1995, the limit has been 55,000 under a permanent diversity program (Statistical Yearbook of the Immigration and Naturalization Service). Table 4.1 depicts the different categories of immigrants under the Immigration Act of 1990. 
Table 4.1: The Immigration Act of 1990

\begin{tabular}{|l|}
\hline Family-sponsored Immigration $\quad$ Total $=226,000^{17}$ \\
First Preference - $10 \%$ to unmarried adult children of U.S. citizens \\
Second Preference - 50\% to spouses and unmarried children of permanent \\
resident aliens \\
Third Preference - $10 \%$ to married children of U.S. citizens \\
Fourth - 30\% to brothers and sisters of adult U.S. citizens \\
\hline Independent Immigration $\quad$ Total = 180,000 (FY1992-1994) \\
Employment-based immigration - 140,000 \\
Priority workers - 40,000 (FY 1995 onward) \\
Professional with advanced degrees - 40,000 \\
Professionals; skilled and unskilled workers (10,000 limit) - 40,000 \\
Special Immigrants - 10,000 \\
Investors of \$1 million - 10,000 \\
Diversity Immigrants - 40,000 (FY 1992-1994) \\
$\quad-55,000$ (FY 1995 onward) \\
\end{tabular}

Family-sponsored immigrants and independent immigrants comprising employmentbased immigrants and diversity immigrants are subject to a worldwide numerical limitation. ${ }^{18}$ Apart from these immigrants, there are legalization dependents that are also subject to the worldwide numerical cap. Legalization dependents are spouses and children of illegal aliens legalized under the provisions of the Immigration Reform and Control Act of 1986. A maximum of 55,000 visas were allotted for this immigrant category. Immediate relatives of U.S. citizens and illegal aliens legalized under the provision of IRCA (1986) are not subject to a numerical cap.

\footnotetext{
${ }^{17}$ This total does not include the immediate relatives of U.S. citizens. The immediate relatives are excluded from the worldwide numerical cap on immigrants.

${ }^{18}$ Immigration law decides how many immigrants worldwide will be granted visas.
} 


\subsection{Trade Liberalization as Experienced by Countries in Our Sample}

Trade liberalization is a central topic of policy discussion and debate. It has been an integral part of trade policy in a large number of countries. This has created pressure for countries that have chosen to be closed economies to reconsider their policy. On the other hand, some countries on the path of liberalization are also evaluating their priorities and considering whether to continue with liberalization. The following discussion provides an overview of the process of liberalization as experienced by the countries in our sample.

We start the discussion with the North American countries (the U.S., Canada and Mexico) that have experienced more or less similar liberalization process due to the preferential trading arrangement among them. The U.S. has been pursuing a policy of trade liberalization, seeking open markets and expanded international trade, for more than half a century. A milestone in the process of trade liberalization was marked by NAFTA (North American Free Trade Agreement in 1994) that extended the bilateral free trade agreement between the U.S. and Canada to a trilateral agreement that included Mexico. The real GDP growth in the U.S. averaged over 2.8\% during the years 1992-1996 and reached a level of 3.9\% in 1997 and 1998. According to a WTO Secretariat report, trade and investment liberalization that resulted due to the Uruguay round agreements and NAFTA, acted as a driving force behind this. A study by the GATT estimated that, by FY 2005, there will be an increase in global production of $\$ 510$ billion (constant 1990 dollars) with the U.S. contributing $\$ 122$ billion. This shows the immense impact of trade 
liberalization on the U.S. economy (World Trade Organization, Trade Policy Reviews, United States, July 1999).

Canada is another country that has been on the path of trade liberalization for several decades. By the end of the 1980s, Canadian tariff rates against U.S. goods averaged around $8 \%$ and was $15 \%$ against all other countries. Due to the staged liberalization scheduled under NAFTA, tariffs were eliminated on vast majority of U.S. and Mexican products (Schwanen, 2001). Antidumping measures that had been a significant barrier to trade in Canada for years have also started declining. Foreign investment in Canada reached a level of U.S. \$143 billion in 1998 from U.S.\$110 billion in 1990 and U.S.\$54 billion in 1980 .

Mexico had a strong protectionist policy until the early 1980's, when it decided to liberalize, culminating with the signing of NAFTA in 1993. Even though trade liberalization in Mexico entered into a new era in 1993, Mexico actually had almost completely eliminated its trade barriers in the manufacturing sector by then (Roberts, 2001). Liberalization actually started in Mexico in 1983. In the first phase of liberalization that took place between 1983 and 1985, import licenses were reduced from $100 \%$ to $83 \%$. By 1988 these were reduced to $22 \%$, with the average tariff rate as low as $11 \%$. Between 1988 and 1992, the focus was on fine-tuning trade and service sector liberalization simultaneously. The NAFTA agreement between the three North American countries marked a new milestone in the history of liberalization. It brought remarkably significant liberalization in the agricultural sector. Tariffs were being eliminated from 
60\% of dutiable goods. By 1998 an additional 9\% could be imported duty-free (Roberts, 2001). The effect of liberalization in Mexico has been remarkable. Reducing dependency on oil exports, Mexico has diversified its exports, and in 1998 Mexican export was - U.S.\$117 billion compared to U.S.\$18 billion in 1980. Foreign direct investment in Mexico has increased, creating more job opportunities and increasing the Mexican wage rate. One would expect that these changes would impact legal (and illegal) immigration.

The next set of countries in our discussion are the three Asian countries that had relatively high tariff rates to begin with in the early 1980s but pursued a rigorous liberalization program to be at par with the rest of the world. For example, Korea revised its trade policy in the latter part of the 1980s as it started assuming new responsibilities commensurate with its enhanced global role. Major objectives of Korea's trade policy include sustaining the momentum of Korea's import liberalization program and removing some institutional barriers blocking increased access to the Korean market. Continued liberalization has increased Korea's import liberalization ratio (number of import free items as a percentage of total import items). By the end of 1999, Korea's import liberalization ratio reached 99.9\% (Association of Foreign Trading Agents of Korea, AFTAK). Throughout the 1990s, Korea continued to remove barriers to encourage foreign direct investment into Korea as well as to enhance outgoing foreign investment. Following the 1997 economic crisis, Korea removed almost all barriers to incoming foreign direct investment. As a result, foreign direct investment in Korea increased from U.S.\$788.5 million in 1990 to U.S.\$5415.6 million in 1998. Foreign investment overseas 
increased from U.S.\$1051.6 million in 1990 to U.S.\$4799.4 million in 1998. By late 1998, the Korean economy started showing positive signs of recovery, and by 1999 all indicators had returned to their pre-crisis levels.

In India, a slow process of liberalization had started in the mid 1980s that was carried forward with the launching of a major program of economic liberalization (stabilization and structural adjustment) in July 1991 (Hussain, 1997). Since then, a tariff reduction program has continued. Tariffs have been reduced from an average of $71 \%$ in 1993 to an average of 35\% in 1998 . The number of goods subject to import licensing has been gradually reduced. Between 1993 and 1996, merchandise exports grew at an annual rate of $20 \%$ in current U.S. dollar terms. Larger flows of foreign direct investment and increased international trade facilitated India's annual growth rate increase in that period (World Trade Organization, Trade Policy Reviews, India, April 1998). Then, a slowdown in 1997 called for even more accelerated reform and faster trade liberalization. Simplifying the foreign investment regime by opening up a number of sectors to foreign direct investment and integration with the world economy can be important for changes in Indian immigration patterns.

Another Asian country in our sample that has liberalized since the early 1980's is the Philippines. Between 1981 and 1985 quantitative restrictions were removed from 900 items and the nominal average tariff protection was brought down from $43 \%$ in 1981 to $28 \%$ in 1985 . However, exports fell and imports taking advantage of the liberalized home industries severely destroyed domestic industries. The Philippines experienced no 
growth between 1983 and 1993. In 1992 there was accelerated privatization, deregulation and liberalization of trade, investment and finance (Bello, 1999). With this economic reform and trade liberalization, the Philippines reduced the average MFN tariff from 26\% in 1992 to $10 \%$ in 1999. Exports rose and the Philippines facilitated the flow of foreign investment and goods that are required to increase the competitiveness.

The other two countries in the study are El Salvador and the United Kingdom. El Salvador adopted a serious stabilization and structural adjustment program in 1989 that resulted in increased economic growth and a fall in inflation. The average real growth in El Salvador between 1992 and 1995 was 6.7\%, and it was between 3.5\% and 4\% in 1996. El Salvador significantly reduced the tariff rates over the period and all rates had been bound $^{19}$ (World Trade Organization, Trade Policy Reviews, El Salvador, November 1996).

The United Kingdom, as a part of the European Union, has been reducing tariff rates for manufacture goods under the Uruguay round commitments (World Trade Organization, Trade Policy Reviews, European Union, July 1995). Under the EU umbrella of tariff cut, the United Kingdom reduced average most favored nation (MFN) tariffs on industrial products to $4.9 \%$ in 1997 . The much higher tariff rates in agriculture were brought down to $20.8 \%$ in 1997.

\footnotetext{
${ }^{19}$ The bound rate for El Salvador implies that tariff rates cannot be increased above these rates.
} 


\subsection{Push-Pull Theory of Migration}

The Harris-Todaro two sector model of migration dominated the migration literature in the developing countries through most of the 1970s. According to Harris-Todaro (1970, AER) migration is affected by wage differentials between regions (within a country or between countries). People move from low-wage areas to high-wage areas. However, Fields (1982) and House and Rempel (1980) showed that changes in conditions at migration origins do not always lead to outcomes predicted by the Harris-Todaro model. In particular, they found that higher incomes in the migration origin do not necessarily deter the flow of out-migration.

In the 1980 s the economists turned their attention to push-pull factors of migration. Any migration is a result of push forces at the origin and pull forces at the destination. Push factors are generally poor economic conditions, lagging employment opportunities in the origin country. Pull factors are prosperous economic conditions and attractive employment opportunities in the destination country. Pull factors cannot be properly evaluated in this study, since we abstract from the choice of destination that the immigrants might consider. Instead, we have only one destination (i.e., the U.S.) and our analysis is focused on the immigrants coming into the U.S.

Zimmermann (1996) explains the push-pull theory of immigration with demand and supply curves as demand-pull and supply-push migration. Figure 4.1 depicts the demand and supply curves. If aggregate demand increases due to a demand shock, then output and 
prices rise. As a consequence, wage increases attracting more immigrants. This leads to a downward shift in the supply curve and $\mathrm{AB}$ in the diagram represents pull immigration. On the other hand, an influx of migrants without a change in the demand curve shifts the supply curve downward, leading to an increase in the output level and fall in prices. In the diagram AC represents supply-push migration. To summarize, supply-push migration affects only the supply curve, whereas demand-pull migration affects the demand curve, which in turn shifts the supply curve. All factors associated with the destination economy that cause migration to happen are considered as the pull factors. Push factors are characteristics of the origin country contributing to migration, i.e., considered as push migration.

\section{Figure 4.1: Push-Pull Migration}

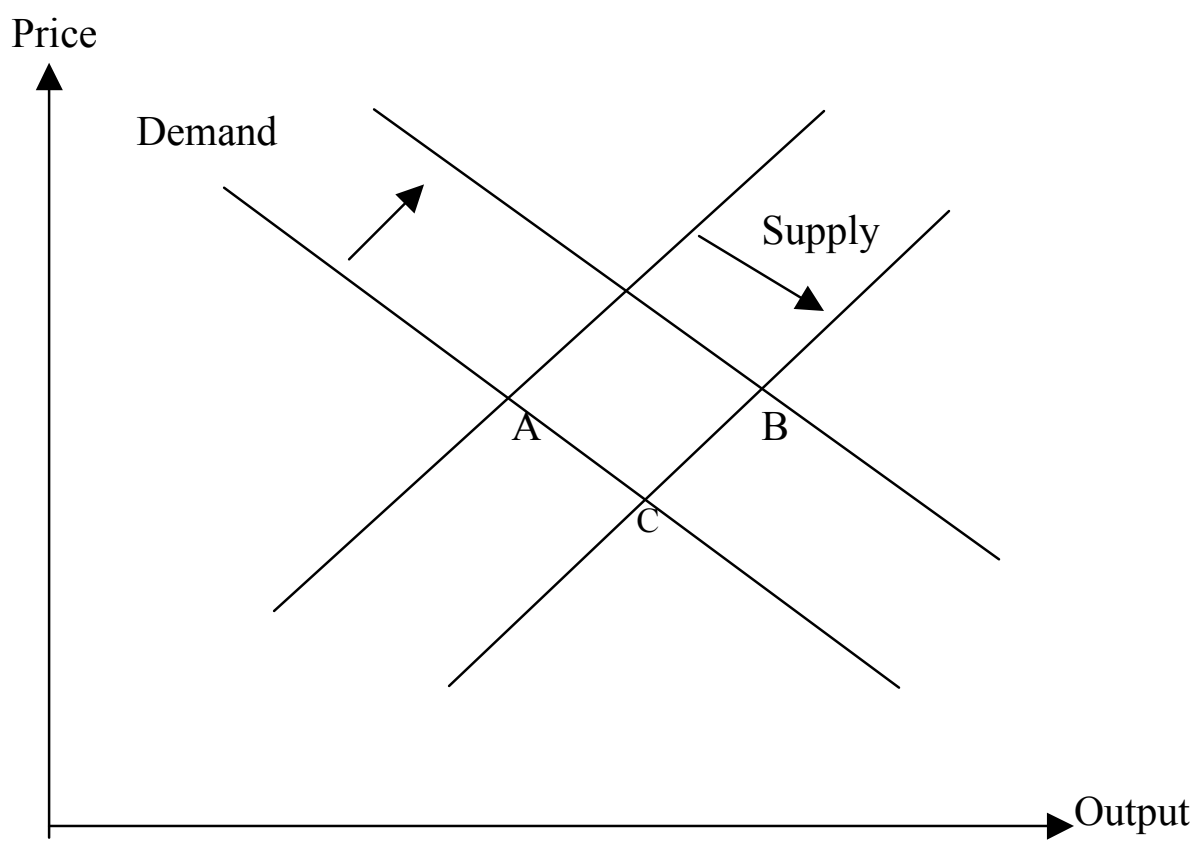
AB: Pull migration
AC: Push migration 


\subsection{Empirical Model}

The empirical model can be specified with the identification of the factors affecting legal immigration to the United States. As mentioned earlier, legal immigrants are measured by the number of skilled immigrants originating from seven different countries. The measure of skilled immigrants is the total number of employment-based and familysponsored immigrants ${ }^{20}$. Countries are selected based on their level of employment and family- sponsored immigrants to the United States. El Salvador, India, the Philippines, Korea, Mexico, Canada and the United Kingdom all have high level of immigrants admitted into the U.S. under the specified categories.

The factors affecting skilled legal immigrants are specific to destination as well as origin countries. The push-pull theory of migration allows us to measure the pull factors coming from the destination and the push factors forcing people to immigrate. We limit our destination to the U.S. alone. This does not allow us to evaluate the cross-country comparison of pull factors.

The various pull and push factors incorporated in our model are the population, gross domestic product (GDP), unemployment rates and tariff rates, of both destination and origin. Population measures the size of the economy and with an increase in population of the origin nation, legal immigration is expected to rise. GDP is a measure of wealth and the wealthier the origin country is, the less will be incentive there for people to

\footnotetext{
${ }^{20}$ Employment-based and family-sponsored immigrants are subject to per country limit. Please see the appendix for details.
} 
migrate. With higher unemployment rate in the origin one should expect legal immigration to rise. Tariff rates are the primary variables in our model measuring protectionism. Low tariff rates indicate that a nation is on the path of liberalization.

Additional regressors are the Immigration Act dummy (whether the fiscal year 1992 or later), the NAFTA dummy (whether the fiscal year 1994 or later), time trend, and two interaction terms. The first interaction term is the product between the tariff rate and the NAFTA dummy and the second interaction term is the tariff rate multiplied by the Immigration Act dummy. Obviously the NAFTA dummy captures the liberalization effect only among the U.S., Canada and Mexico. The remaining variables incorporated in the model are: education levels of the origin countries, the wage difference between skilled and unskilled labor in the U.S., and antidumping actions taken by the U.S. between 1980 and 1998. "Dumping" in international trade refers to a situation where exports are priced below the level that prevails in the exporting nation. Under the General Agreement of Tariff and Trade (GATT), member countries are allowed to take actions to counteract the effects of dumping if injury made is established. Therefore, antidumping actions can act as non-tariff barriers and retard the process of liberalization. However, we do not have information about antidumping actions taken by the U.S. against the countries in our sample. Data covers total antidumping actions by the U.S. against all countries for each fiscal year from 1980 to 1998 (Zang, 2001). 
The total number of skilled legal immigrants ${ }^{21}$ entering the U.S. at any time $t\left(\mathrm{LM}_{\mathrm{t}}\right)$ can be expressed as:

$\operatorname{lnLM}_{t}=b_{0}+b_{1} \operatorname{lnTARORG}{ }_{t}+b_{2} \operatorname{lnTARDEST}_{t}+b_{3} \operatorname{lnPOPORG}_{t}+b_{4} \operatorname{lnPOPDEST}_{t}+$ $\mathrm{b}_{5} \operatorname{lnGDPORG}_{\mathrm{t}}+\mathrm{b}_{6} \operatorname{lnGDPDEST}_{\mathrm{t}}+\mathrm{b}_{7} \operatorname{lnEDUORG}_{\mathrm{t}}+\mathrm{b}_{8} \ln \mathrm{WGPREMDEST}_{\mathrm{t}}+\mathrm{b}_{9} \mathrm{D}_{\text {IMMACT }}$ $+\mathrm{b}_{10} \mathrm{D}_{\mathrm{NAFTA}}+\mathrm{b}_{10} \mathrm{TIME}+\mathrm{e}_{\mathrm{t}}$

where the b's are coefficients and e is the error term that is normally distributed with mean zero. The model is estimated for the time period between 1980 and 1998. The double log specification allows us to interpret the coefficients as elasticities. Following is the list of the variables included in the model: TARORG is tariff of the origin country ${ }^{22}$, TARDEST is tariff of the destination, POPORG is population of the origin, POPDEST is population of the destination, GDPORG is GDP of the origin, GDPDEST is GDP of the destination, EDUORG is the level of education in the origin, WGPREMDEST is the difference in the skilled and unskilled wage in the destination, $\mathrm{D}_{\text {IMMACT }}$ is the Immigration Act dummy, $\mathrm{D}_{\mathrm{NAFTA}}$ is the NAFTA dummy and TIME is the time trend.

\subsection{Data}

Data on skilled legal immigration measured by the total number of employment-based and family-based immigrants is obtained from the Statistical Yearbook of the Immigration and Naturalization Service for each fiscal year from 1980 to 1998. The average tariff rates of both countries are calculated by taking the ratio of tariff revenues

\footnotetext{
${ }^{21}$ Figure 4.2 shows the number of skilled legal immigrants from the origin nation between 1980 and 1998.

${ }^{22}$ Figure 4.3 and 4.4 depict the movement of the tariff rates for the origin countries between 1980 and 1998.
} 
collected to the total value of imports. This measure of the average tariff rate is the same as the trade-weighted average tariff that weighs each tariff by the share of total imports in that import category. Tariff revenues for both countries are available from Government Finance Statistics Yearbook published by the IMF. GDP, population, and unemployment rates of the origins and the destination are obtained from the World Development Indicators of the World Bank for the period of 1980-1998. The education variable of the origin countries is the secondary school enrollment rate. It follows the definition of the International Standard Classification of Education on net secondary school enrollment ratio. It is the ratio (in percentage) of the number of children of official school age (as defined by the national education system) who are enrolled in school, to the population of the corresponding official school age. This data is also available in the World Development Indicators of the World Bank. The Bureau of Labor Statistics publishes the skilled destination (i.e. the U.S.) wage rate and the unskilled wage rate is obtained from the U.S. Department of Agriculture (USDA). The Congressional budget office is the source for antidumping action data.

\subsection{Estimation Results}

As mentioned earlier, skilled legal immigration is estimated in log form as a function of $\log$ dependent variables. An ordinary least squared method, a fixed effect technique, and a generalized least squared (GLS) method with heteroscedastic errors are used to estimate several specifications of skilled legal immigration. Results are presented in Tables 4.24.5. The fixed effect model is estimated to take into account the country-specific effects 
and it is assumed that country-specific effects vary systematically among the origin countries. Destination-country fixed effect estimation is not possible since there is a single destination in our sample. The incorporation of fixed effects causes a technical problem when explanatory variables are invariant over time and within groups for which a cross section panel is formed (Wooldridge, 2002). However, we do not have any invariant explanatory variable in our model. The generalized least squared model with heteroscedastic error allows variance for each of the panels to differ. We have different countries in our sample, with dissimilar characteristics that make the application of the GLS model with the heteroscedastic error structure appropriate.

The coefficient of the regressors can be interpreted as elasticities. For example, our results infer that skilled legal immigration is elastic with respect to the population of the destination. Results show that the origin country tariff rate is significant and has a positive effect on skilled immigration. This implies that, with liberalization, the flow of skilled legal immigration will decrease. As a consequence of liberalization, skilled workers have better opportunities in their home country that reduces their incentive to migrate. Population of the origin countries appears to have a significantly positive effect on immigration. This is quite obvious, since growing population contributes positively to the number of immigrants. GDP of the origin countries also plays an important role; as with increasing GDP, legal immigration falls significantly. With higher levels of education in the origin countries, skilled legal immigration gets positive (significant) stimulus. The unemployment rate of the origin country has a significantly negative effect on legal immigration in the OLS estimation, whereas it is insignificant in fixed effect and 
GLS estimation. This might seem counter-intuitive. However, if the economy is characterized by dualism, then skilled workers may be employed at high industrial wages, whereas there is unemployment in the entire economy. Hence, the skilled workers have no incentive to migrate. This study is concerned only about the skilled workers and the unemployment rate data does not reflect the true picture of unemployment among skilled people. The difference between the skilled and unskilled U.S. wage turns out to be insignificant in all regressions. Antidumping actions taken by the U.S. that act as nontariff barriers do not have any significant impact on our dependant variable. NAFTA and Immigration Act dummies are significant in most regression results and where they are significant they affect immigration positively. This implies that with the introduction of NAFTA and the Immigration Act, skilled legal immigration has risen. The interaction terms between the origin tariff rate and the NAFTA dummy and also the origin tariff rate and the Immigration Act dummy are found to have positive and significant effects in some of our estimated models. This implies that, once NAFTA and the Immigration Act got into effect, the tariff rate of the origin country has a positive impact on immigration. This makes the overall impact of the origin tariff rate more pronounced in the postNAFTA and Immigration Act periods. ${ }^{23}$

\subsection{Summary and Conclusion}

This study attempts to link trade liberalization to U.S. legal immigration. Based on legal immigration from seven countries with different characteristics, we try to evaluate the

${ }^{23}$ We also carry out a stepwise estmation. 
significance of the push factors in the origin nations for the flow of legal immigration. Increasing liberalization has been found to impede the flow of legal immigration significantly. This result is very robust across different estimated models. Growing populations of the origin countries stimulate the flow of legal immigration. On the other hand, a higher GDP at origin reduces the flow of legal immigration. NAFTA and the Immigration Act also affect immigration positively. This throws light on the U.S. immigration policy and North American trilateral trading arrangement. In short, we can say that in order to keep legal immigration to a desired level, the U.S. should encourage liberalization in the origin countries. 
Table 4.2: OLS, Fixed Effect and GLS Estimation of the first model

\begin{tabular}{|c|c|c|c|}
\hline & OLS & Fixed Effect & GLS \\
\hline \multirow[t]{2}{*}{ Constant } & 247.73 & 450.61 & 250.6 \\
\hline & $(750.68)$ & $(444.94)$ & $(559.32)$ \\
\hline \multirow[t]{2}{*}{ Log of origin tariff rate } & $0.27 * * *$ & $0.11 * *$ & $0.17^{* * *}$ \\
\hline & $(0.08)$ & $(0.05)$ & $(0.06)$ \\
\hline \multirow[t]{2}{*}{ Log of destination tariff rate } & 0.17 & 0.00 & 0.00 \\
\hline & $(1.21)$ & $(0.71)$ & $(0.89)$ \\
\hline \multirow[t]{2}{*}{ Log of origin population } & $0.17 * * *$ & $1.09^{* * *}$ & $0.20^{* * *}$ \\
\hline & $(0.06)$ & $(0.31)$ & $(0.04)$ \\
\hline \multirow[t]{2}{*}{ Log of destination population } & -8.87 & -16.28 & -7.14 \\
\hline & $(31.48)$ & $(18.6)$ & $(23.4)$ \\
\hline \multirow[t]{2}{*}{ Log of origin GDP } & $-0.35^{* * *}$ & $-0.76^{* * *}$ & $-0.35^{* * *}$ \\
\hline & $(0.09)$ & $(0.23)$ & $(0.06)$ \\
\hline \multirow[t]{2}{*}{ Log of destination GDP } & -2.27 & -4.39 & -3.49 \\
\hline & $(7.9)$ & $(4.69)$ & $(5.82)$ \\
\hline \multirow[t]{2}{*}{ Log of origin unemployment rate } & $-0.24 * * *$ & -0.13 & -0.09 \\
\hline & $(0.07)$ & $(0.14)$ & $(0.06)$ \\
\hline \multirow[t]{2}{*}{ Log of destination unemployment rate } & -0.54 & -0.74 & -0.91 \\
\hline & $(1.33)$ & $(0.79)$ & $(0.97)$ \\
\hline Log of diff b/ween skilled \& unskilled wage & 1.50 & 0.68 & 1.31 \\
\hline in destination & $(2.18)$ & $(1.30)$ & $(1.59)$ \\
\hline \multirow[t]{2}{*}{ Log of origin education } & $0.75^{* * *}$ & 0.48 & $0.79^{* * *}$ \\
\hline & $(0.20)$ & $(0.37)$ & $(0.15)$ \\
\hline \multirow[t]{2}{*}{ Immigration Act dummy } & $0.70 * *$ & $0.61 * * *$ & $0.53^{* *}$ \\
\hline & $(0.30)$ & $(0.18)$ & $(0.22)$ \\
\hline \multirow[t]{2}{*}{ NAFTA dummy } & $0.80 * * *$ & $0.48^{* * *}$ & $0.44 * *$ \\
\hline & $(0.21)$ & $(0.13)$ & $(0.21)$ \\
\hline \multirow[t]{2}{*}{ Time } & 0.06 & 0.23 & 0.09 \\
\hline & $(0.41)$ & $(0.24)$ & $(0.31)$ \\
\hline Number of observations & 132 & 132 & 132 \\
\hline Adjusted R-squared & 0.49 & 0.38 & \\
\hline
\end{tabular}

Note:

1. *, $* *, * * *$ imply significance at $10 \%, 5 \%$ and $1 \%$ level of significance respectively under a two -tailed test

2. Standard errors are listed in the parantheses

3. GLS model assumes heteroscedastic error structure. 
Table 4.3: OLS, Fixed Effect and GLS Estimation of the second model

\begin{tabular}{|c|c|c|c|}
\hline & OLS & Fixed Effect & GLS \\
\hline \multirow[t]{2}{*}{ Constant } & 51.22 & 384.43 & 184.92 \\
\hline & $(723.26)$ & $(446.08)$ & $(504.56)$ \\
\hline \multirow[t]{2}{*}{ Log of origin tariff rate } & $0.23 * * *$ & $0.10 *$ & $0.15^{* * *}$ \\
\hline & $(0.08)$ & $(0.05)$ & $(0.05)$ \\
\hline \multirow[t]{2}{*}{ Log of destination tariff rate } & 0.15 & -0.01 & -0.03 \\
\hline & $(1.16)$ & $(0.71)$ & $(0.80)$ \\
\hline \multirow[t]{2}{*}{ Log of origin tariff rate $\times$ NAFTA dummy } & $1.06 * * *$ & 0.28 & $1.26 * * *$ \\
\hline & $(0.32)$ & $(0.21)$ & $(0.38)$ \\
\hline \multirow[t]{2}{*}{ Log of origin population } & $0.17 * * *$ & $1.11 * * *$ & $0.20 * * *$ \\
\hline & $(0.06)$ & $(0.31)$ & $(0.04)$ \\
\hline \multirow[t]{2}{*}{ Log of destination population } & -2.48 & -13.97 & -4.63 \\
\hline & $(30.29)$ & $(18.62)$ & $(21.13)$ \\
\hline \multirow[t]{2}{*}{ Log of origin GDP } & $-0.34 * * *$ & $-0.76^{* * *}$ & $-0.33 * * *$ \\
\hline & $(0.08)$ & $(0.22)$ & $(0.05)$ \\
\hline \multirow[t]{2}{*}{ Log of destination GDP } & 0.24 & -3.64 & -2.90 \\
\hline & $(7.62)$ & $(4.71)$ & $(5.24)$ \\
\hline \multirow[t]{2}{*}{ Log of origin unemployment rate } & $-0.18^{* *}$ & -0.14 & -0.04 \\
\hline & $(0.07)$ & $(0.14)$ & $(0.06)$ \\
\hline \multirow[t]{2}{*}{ Log of destination unemployment rate } & -0.09 & -0.62 & -0.78 \\
\hline & $(1.28)$ & $(0.79)$ & $(0.88)$ \\
\hline Log of diff b/ween skilled \& unskilled wage & 0.91 & 0.59 & 1.09 \\
\hline in destination & $(2.10)$ & $(1.30)$ & $(1.43)$ \\
\hline \multirow[t]{2}{*}{ Log of origin education } & $0.79 * * *$ & 0.40 & $0.82^{* * *}$ \\
\hline & $(0.19)$ & $(0.37)$ & $(0.14)$ \\
\hline \multirow[t]{2}{*}{ Immigration Act dummy } & $0.55^{*}$ & $0.58^{* * *}$ & $0.48 * *$ \\
\hline & $(0.29)$ & $(0.18)$ & $(0.20)$ \\
\hline \multirow[t]{2}{*}{ NAFTA dummy } & 0.18 & $0.32 *$ & -0.15 \\
\hline & $(0.27)$ & $(0.17)$ & $(0.25)$ \\
\hline \multirow[t]{2}{*}{ Time } & -0.04 & 0.19 & 0.05 \\
\hline & $(0.39)$ & $(0.24)$ & $(0.28)$ \\
\hline Number of observations & 132 & 132 & 132 \\
\hline Adjusted R-squared & 0.53 & 0.38 & \\
\hline
\end{tabular}

Note:

1. $*, * *, * * *$ imply significance at $10 \%, 5 \%$ and $1 \%$ level of significance respectively under a two -tailed test

2. Standard errors are listed inside parentheses.

3. GLS model assumes heteroscedastic error structure. 
Table 4.4: OLS, Fixed Effect and GLS Estimation of the third model

\begin{tabular}{|c|c|c|c|}
\hline & OLS & Fixed Effect & GLS \\
\hline \multirow[t]{2}{*}{ Constant } & 153.77 & 416.87 & 135.29 \\
\hline & $(742.24)$ & $(438.96)$ & $(541.99)$ \\
\hline \multirow[t]{2}{*}{ Log of origin tariff rate } & $0.28 * * *$ & $0.11 * *$ & $0.19 * * *$ \\
\hline & $(0.08)$ & $(0.05)$ & $(0.06)$ \\
\hline \multirow[t]{2}{*}{ Log of destination tariff rate } & 0.21 & 0.00 & 0.05 \\
\hline & $(1.20)$ & $(0.7)$ & $(0.86)$ \\
\hline \multirow[t]{2}{*}{ Log of origin tariff rate $\times$ Immigration Act dummy } & $0.11 * *$ & $0.08 * *$ & $0.10 * *$ \\
\hline & $(0.05)$ & $(0.04)$ & $(0.04)$ \\
\hline \multirow[t]{2}{*}{ Log of origin population } & $0.14 * *$ & $0.84 * *$ & $0.17 * * *$ \\
\hline & $(0.06)$ & $(0.33)$ & $(0.04)$ \\
\hline \multirow[t]{2}{*}{ Log of destination population } & -5.06 & -14.35 & -2.17 \\
\hline & $(31.12)$ & $(18.37)$ & $(22.69)$ \\
\hline \multirow[t]{2}{*}{ Log of origin GDP } & $-0.32 * * *$ & $-0.88 * * *$ & $-0.32 * * *$ \\
\hline & $(0.09)$ & $(0.23)$ & $(0.05)$ \\
\hline \multirow[t]{2}{*}{ Log of destination GDP } & -1.57 & -4.27 & -2.82 \\
\hline & $(7.8)$ & $(4.63)$ & $(5.63)$ \\
\hline \multirow[t]{2}{*}{ Log of origin unemployment rate } & $-0.25 * * *$ & -0.11 & -0.10 \\
\hline & $(0.07)$ & $(0.14)$ & $(0.06)$ \\
\hline \multirow[t]{2}{*}{ Log of destination unemployment rate } & -0.46 & -0.73 & -0.87 \\
\hline & $(1.31)$ & $(0.78)$ & $(0.94)$ \\
\hline Log of diff $b /$ ween skilled \& unskilled wage & 1.49 & 0.73 & 1.30 \\
\hline in destination & $(2.15)$ & $(1.28)$ & $(1.53)$ \\
\hline \multirow[t]{2}{*}{ Log of origin education } & $0.71 * * *$ & 0.42 & $0.74 * * *$ \\
\hline & $(0.2)$ & $(0.36)$ & $(0.14)$ \\
\hline \multirow[t]{2}{*}{ Immigration Act dummy } & $0.52 *$ & $0.49 * * *$ & $0.35^{*}$ \\
\hline & $(0.31)$ & $(0.19)$ & $(0.23)$ \\
\hline \multirow[t]{2}{*}{ NAFTA dummy } & $0.92 * * *$ & $0.53 * * *$ & $0.55 * * *$ \\
\hline & $(0.21)$ & $(0.13)$ & $(0.21)$ \\
\hline \multirow[t]{2}{*}{ Time } & 0.01 & 0.21 & 0.02 \\
\hline & $(0.4)$ & $(0.24)$ & $(0.3)$ \\
\hline Number of observations & 132 & 132 & 132 \\
\hline Adjusted R-squared & 0.51 & 0.40 & \\
\hline
\end{tabular}

Note:

1. $*, * *, * * *$ imply significance at $10 \%, 5 \%$ and $1 \%$ level of significance respectively under a two -tailed test

2. Standard errors are listed inside parentheses.

3. GLS model assumes heteroscedastic error structure. 
Table 4.5: OLS, Fixed Effect and GLS Estimation of the fourth model

\begin{tabular}{|c|c|c|c|}
\hline & OLS & Fixed Effect & GLS \\
\hline \multirow[t]{2}{*}{ Constant } & -92.03 & 317.23 & 24.76 \\
\hline & $(724.73)$ & $(444.01)$ & $(485.87)$ \\
\hline \multirow[t]{2}{*}{ Log of origin tariff rate } & $0.25 * * *$ & $0.11 *$ & $0.16^{* * *}$ \\
\hline & $(0.08)$ & $(0.05)$ & $(0.05)$ \\
\hline \multirow[t]{2}{*}{ Log of destination tariff rate } & 0.10 & -0.05 & -0.04 \\
\hline & $(1.16)$ & $(0.71)$ & $(0.77)$ \\
\hline \multirow[t]{2}{*}{ Log of antidumping actions by U.S. } & -0.11 & -0.07 & -0.10 \\
\hline & $(0.12)$ & $(0.07)$ & $(0.08)$ \\
\hline \multirow[t]{2}{*}{ Log of origin tariff rate $\times$ Immigration act dummy } & $0.09 *$ & $0.08 *$ & $0.09 * *$ \\
\hline & $(0.05)$ & $(0.04)$ & $(0.04)$ \\
\hline \multirow[t]{2}{*}{ Log of origin tariff rate $\times$ NAFTA dummy } & $0.99 * * *$ & 0.24 & $1.20 * * *$ \\
\hline & $(0.32)$ & $(0.21)$ & $(0.38)$ \\
\hline \multirow[t]{2}{*}{ Log of origin population } & $0.15 * *$ & $0.84 * *$ & $0.17 * * *$ \\
\hline & $(0.06)$ & $(0.33)$ & $(0.04)$ \\
\hline \multirow[t]{2}{*}{ Log of destination population } & -1.45 & -13.65 & -1.83 \\
\hline & $(30.17)$ & $(18.46)$ & $(20.25)$ \\
\hline \multirow[t]{2}{*}{ Log of origin GDP } & $-0.31 * * *$ & $-0.88 * * *$ & $-0.31 * * *$ \\
\hline & $(0.08)$ & $(0.23)$ & $(0.05)$ \\
\hline \multirow[t]{2}{*}{ Log of destination GDP } & 4.41 & -1.34 & 0.69 \\
\hline & $(8.61)$ & $(5.27)$ & $(5.66)$ \\
\hline \multirow[t]{2}{*}{ Log of origin unemployment rate } & $-0.20 * * *$ & -0.13 & -0.05 \\
\hline & $(0.07)$ & $(0.14)$ & $(0.06)$ \\
\hline \multirow[t]{2}{*}{ Log of destination unemployment rate } & 0.74 & -0.14 & -0.10 \\
\hline & $(1.54)$ & $(0.94)$ & $(1.00)$ \\
\hline Log of diff b/ween skilled \& unskilled wage & 1.10 & 0.77 & 1.27 \\
\hline in destination & $(2.09)$ & $(1.29)$ & $(1.37)$ \\
\hline \multirow[t]{2}{*}{ Log of origin education } & $0.75 * * *$ & 0.38 & $0.77 * * *$ \\
\hline & $(0.19)$ & $(0.37)$ & $(0.13)$ \\
\hline \multirow[t]{2}{*}{ Immigration Act dummy } & 0.36 & $0.44^{* *}$ & 0.27 \\
\hline & $(0.31)$ & $(0.19)$ & $(0.21)$ \\
\hline \multirow[t]{2}{*}{ NAFTA dummy } & 0.32 & $0.40 * *$ & -0.01 \\
\hline & $(0.28)$ & $(0.18)$ & $(0.26)$ \\
\hline \multirow[t]{2}{*}{ Time } & -0.16 & 0.14 & -0.07 \\
\hline & $(0.40)$ & $(0.25)$ & $(0.27)$ \\
\hline Number of observations & 132 & 132 & 132 \\
\hline Adjusted R-squared & 0.60 & 0.41 & \\
\hline
\end{tabular}

Note:

1. *, $* *, * * *$ imply significance at $10 \%, 5 \%$ and $1 \%$ level of significance respectively under a two -tailed test

2. Standard errors are listed inside parentheses.

3. GLS model assumes heteroscedastic error structure. 
Table 4.6: Descriptive statistics of the variables

\begin{tabular}{|l|l|l|l|l|l|}
\hline Variable & Mean & Median & Std. Dev & Min & Max \\
\hline $\begin{array}{l}\text { Number of skilled legal } \\
\text { immigration }\end{array}$ & 14974 & 16761 & 9615 & 3451 & 63585 \\
\hline $\begin{array}{l}\text { Origin tariff rate } \\
\text { (in percentage) }\end{array}$ & 11.75 & 5.74 & 19.53 & 0.01 & 170.31 \\
\hline $\begin{array}{l}\text { Destination tariff rate } \\
\text { (in percentage) }\end{array}$ & 3.03 & 3.16 & 0.49 & 1.94 & 3.56 \\
\hline $\begin{array}{l}\text { Number of Antidumping } \\
\text { actions by the U.S. }\end{array}$ & 39 & 36 & 21 & 14 & 83 \\
\hline Origin population & $1.57 \mathrm{e}+08$ & $5.39 \mathrm{e}+07$ & $2.70 \mathrm{e}+08$ & $3.82 \mathrm{e}+06$ & $9.80 \mathrm{e}+08$ \\
\hline Destination population & $2.49 \mathrm{e}+08$ & $2.47 \mathrm{e}+08$ & $1.44 \mathrm{e}+07$ & $2.27 \mathrm{e}+08$ & $2.75 \mathrm{e}+08$ \\
\hline $\begin{array}{l}\text { Origin unemployment rate } \\
\text { (in percentage) }\end{array}$ & 9.74 & 8.10 & 7.08 & 2.00 & 35.65 \\
\hline $\begin{array}{l}\text { Destination } \\
\text { unemployment rate } \\
\text { (in percentage) }\end{array}$ & 6.63 & 6.80 & 1.37 & 4.60 & 9.70 \\
\hline $\begin{array}{l}\text { Origin education rate } \\
\text { (in percentage) }\end{array}$ & 66.03 & 73.22 & 23.41 & 24.31 & 97.69 \\
\hline
\end{tabular}


Figure 4.2: Legal Immigrants

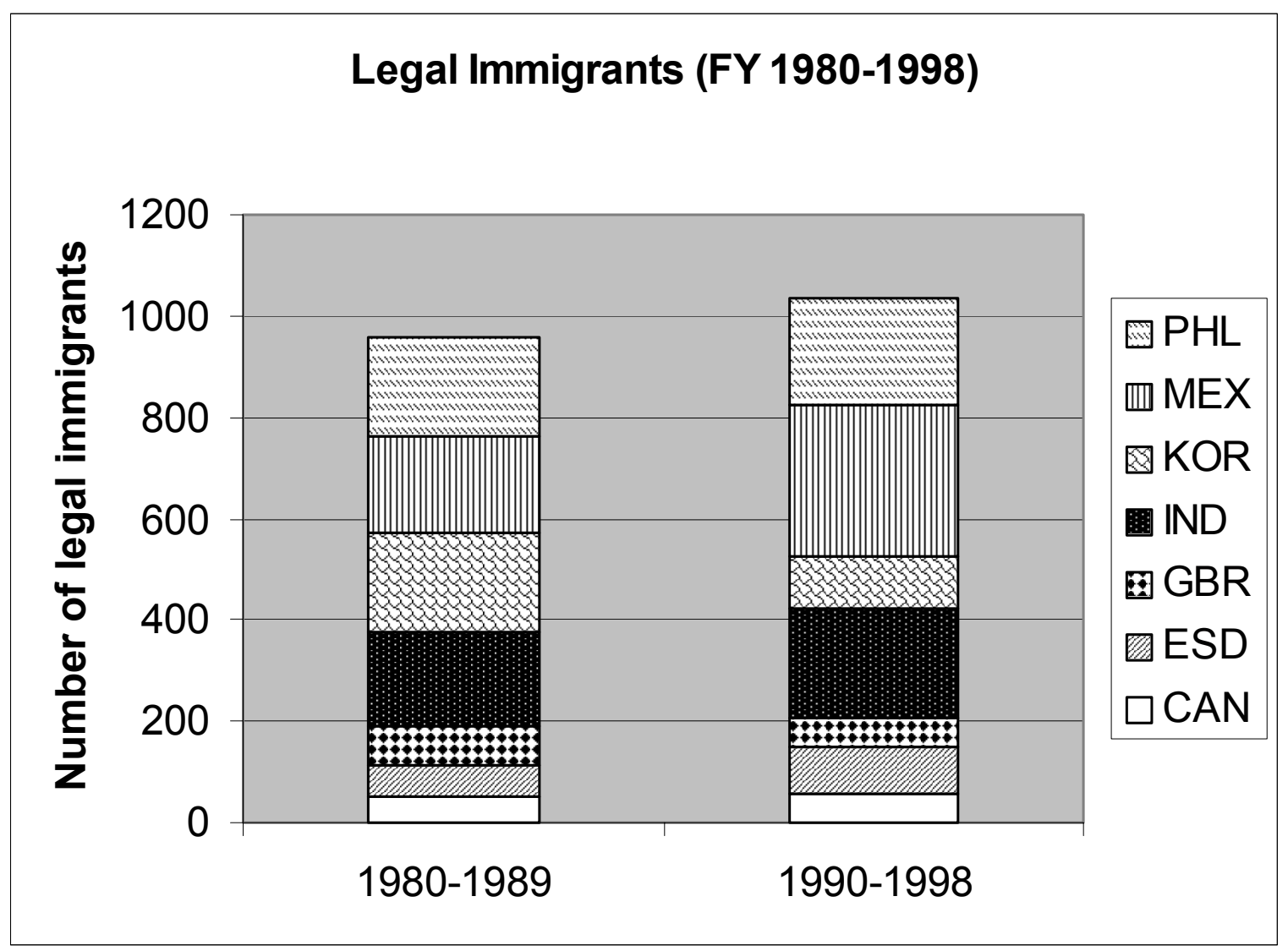

The abbreviation list for the countries are as follows:

PHL is the Philippines, MEX ix Mexico, KOR is Korea, IND is India, GBR is the United Kingdom, ESD is El Salvador and CAN is Canada. 
Figure 4.3: Origin Tariff Rate for Selected Economies

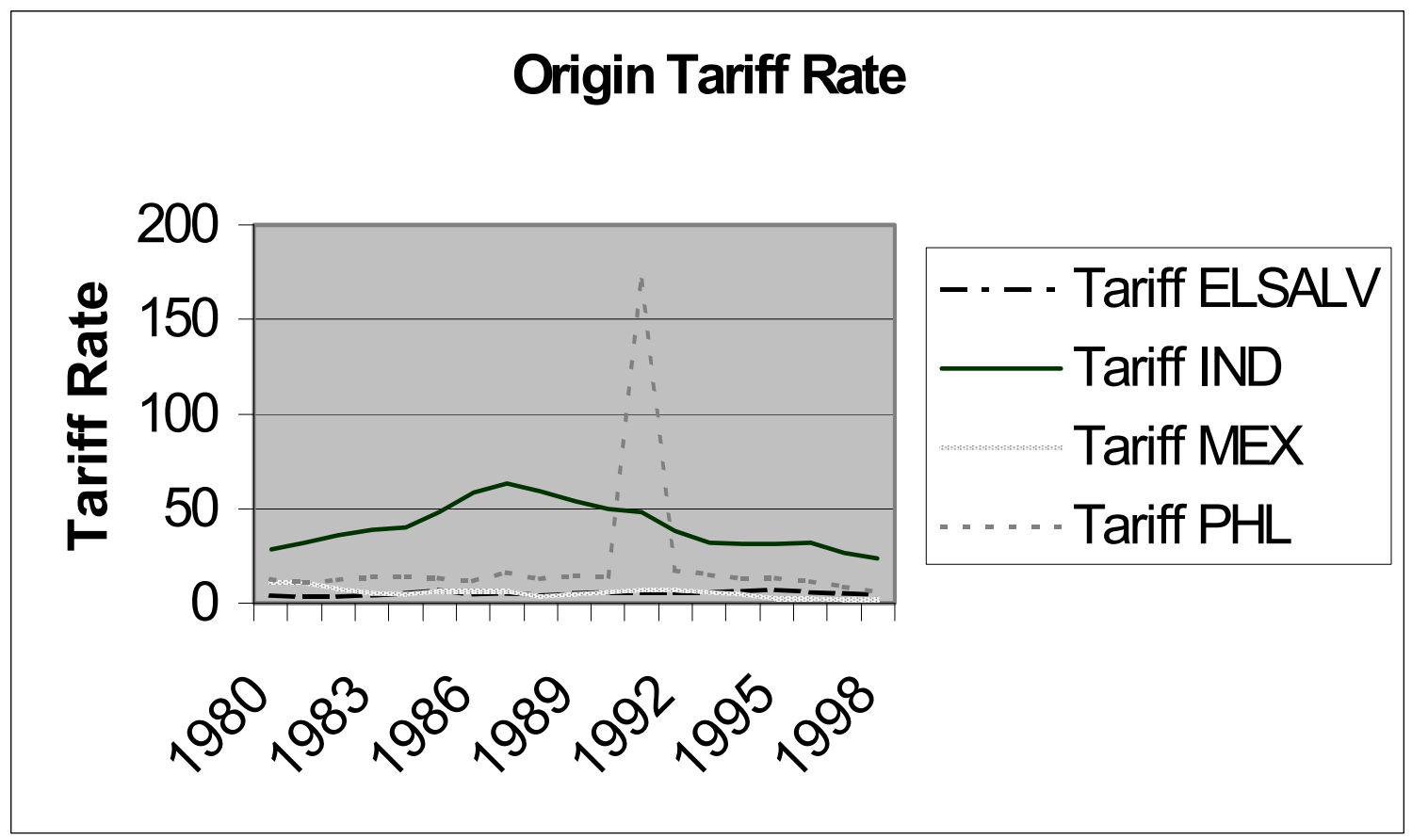

Figure 4.4: Origin Tariff Rate for Selected Economies

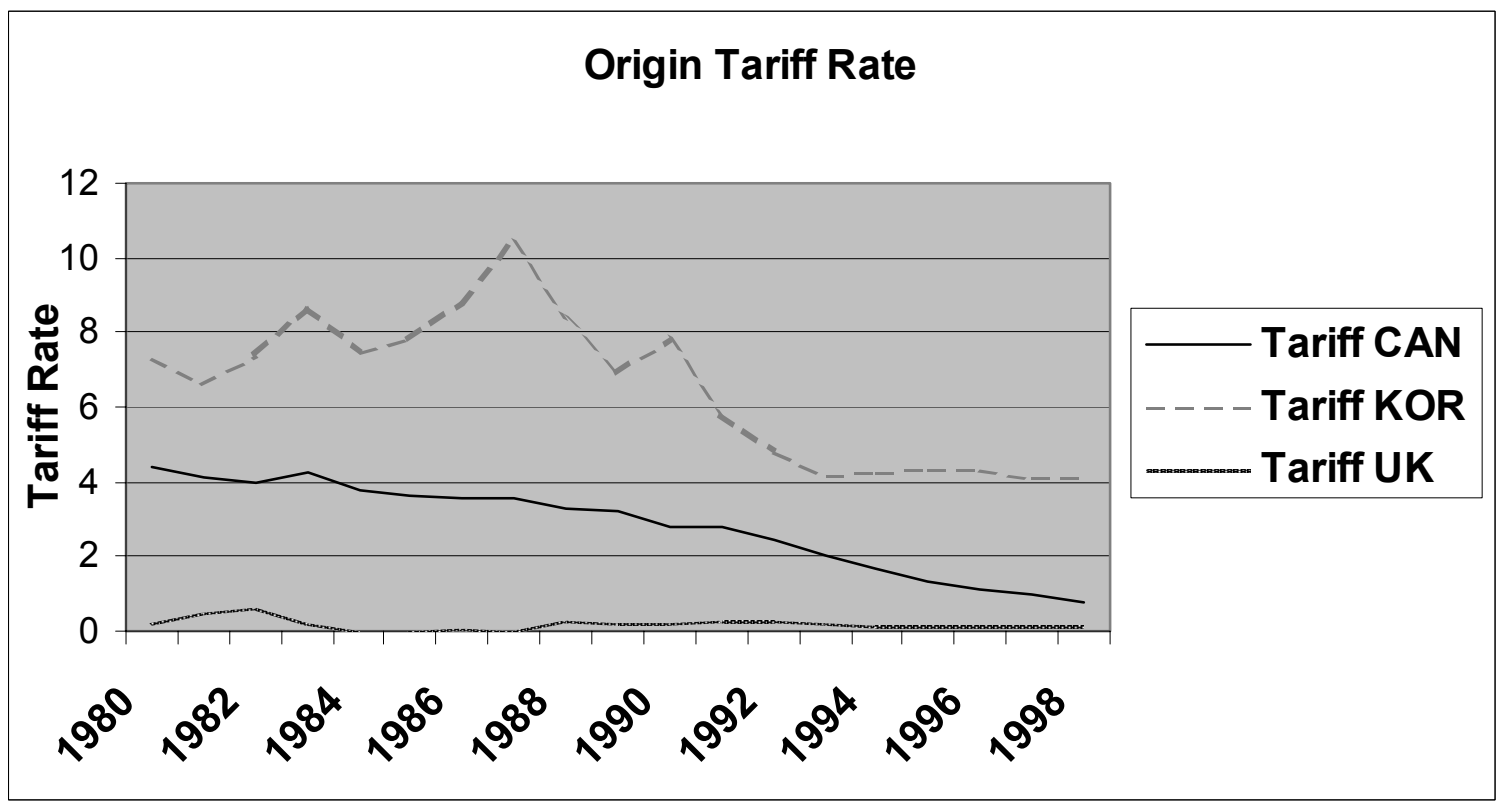




\section{Appendix}

Per-country limit is the maximum number of family-sponsored and employment-based preference visas that can be issued to the citizens of any country in a fiscal year. Between FY 1980-1992 per country limit was 20,000. According to the Immigration Act of 1990, per country limit was calculated each year from FY 1992 onward, depending on the total number of family-sponsored and employment visas available. No more than $7 \%$ of the visas can be issued to citizens of any independent country and no more than $2 \%$ can be issued to any one dependency of any independent country. Generally, this limit set by the INS is not strictly followed by each and every country. The limit may vary depending on the number of applicants. Also, most countries do not reach the limit of maximum number of visa issuance every year. Therefore, we do not consider the per-country limit in our analysis. 


\section{Chapter 5}

\section{Conclusion and Summary}

Chapter 2 presents the first essay of the dissertation, analyzing the welfare effects of transfers under bilateral and multilateral cases. It finds that under bilateral transfer, immiserization cannot be ruled out if the recipient's tax rate exceeds that of the nonparticipant. The study finds that multilateral transfers made in proportion to the exports of the two exporting nations must raise A's welfare, provided nation B has a sufficiently small tax response. Multilateral transfers that are not proportional to the exports of the recipient nations are likely to reduce the welfare of nation $\mathrm{A}$, provided it receives a smaller share of the total transfer. When equal transfers are made, asymmetry between the recipients is found to play an important role for recipient immiserization. The study finds that the nation imposing the higher tax rate is likely to be immiserized from equal transfers. Hence, being more aggressive in taxation is a disadvantage in terms of gaining from the receipts of transfer. The larger exporter exercises more market power and is also more vulnerable to the adverse welfare effects of a transfer.

Several primary product-exporting nations employ export taxes. For example, nations like Cote d'Ivoire and Brazil export cocoa and also employ export taxes. These taxes may be imposed for various reasons, including raising tax revenues and/or improving terms of trade. Clearly, the world cocoa price is dependent on the tax policies of each of 
these exporting nations and the trade policies of these nations are interdependent. ${ }^{24}$ In reality, aid is provided simultaneously by the multilateral agencies to several primary product- exporting, developing nations and these nations vary in terms of their market share and export taxes. Thus, asymmetry between exporting nations is crucial in analyzing the effects of transfers. ${ }^{25}$ The first essay provides a framework for analyzing these issues and finds interesting implications of asymmetry between exporting nations. It suggests that in order to avoid undesirable outcomes, the interdependence and size of nations should be considered in aid decisions by the donor agencies (or nations).

The second essay, in Chapter 3, finds that Mexican tariff rates have a significant effect on illegal immigration from Mexico to the U.S. Results show that as Mexico pursues trade liberalization policies, the flow of illegal immigration from Mexico to the U.S. falls. This is consistent with the Heckscher-Ohlin model. However, border patrol budget or border patrol hours do not appear to have a significant impact on apprehension. The finding is very interesting, because it suggests that trade policy may be a more effective tool in controlling illegal immigration than immigration policy.

Traditional analysis of illegal immigration has focused on enforcement as the relevant policy tool for controlling illegal immigration. The second essay focuses on the effects of

\footnotetext{
${ }^{24}$ See Yilmaz (1999) for interesting institutional factors about the global cocoa market. He writes (page441): “...with 22percent market share in 1986, Brazil cannot ignore the reaction of Cote d'Ivoire, which had a 29.5percent market share, while setting the export tax on cocoa."

${ }^{25}$ Analysis of asymmetry occupies an important place in the trade policy literature. See for example, Kennan and Riezman (1988).
} 
trade liberalization on illegal immigration. While tariff liberalization by the source (or origin) nation (say Mexico) may not be the policy tool of the host (or destination) nation (e.g. the U.S.), it is often possible for the richer (and more powerful) host nation to influence the source nation's trade policy. This offers an alternate policy tool for controlling illegal immigration. The empirical analysis establishes that trade liberalization has significant effects on illegal immigration and helps to reduce the problem.

The third essay, in Chapter 4 finds that the push factors in the origin countries that force people to migrate, are very crucial for the level of legal immigration. Increasing liberalization has been found to impede the flow of legal immigration significantly. Growing population of the origin countries is found to stimulate the flow of legal immigration, whereas, a higher GDP at origin reduces the flow of legal immigration. NAFTA and the Immigration Act also affect immigration positively. This throws light on U.S. immigration policy and the North American trilateral trading arrangement. To summarize, we can say that the instrument for curbing the flow of legal immigration is to encourage liberalization in the origin countries. The key finding in this analysis is that trade liberalization has significant dampening effects on the volume of legal immigration. Hence, the empirical analysis of legal immigration in the third essay further strengthens the case for using trade policy to control immigration. 


\section{References}

Acevedo, Dolores. and Thomas J. Espenshade, 1992. "Implications of a North American Free Trade Agreement for Mexican Migration into the United States.” Population and Development Review, Vol. 18, 729-744.

Association of Foreign Trading Agency of Korea (AFTAK). Trade Policy. http://www.aftak.or.kr/a2_1.html.

Bandyopadhyay, Subhayu, 1992. Export Taxation in a Multicountry General Equilibrium

Framework, Ph.D. Dissertation, University of Maryland.

Bandyopadhyay, Subhayu., 1995. "Foreign Investment in the Exporting Sector-Welfare

Enhancing or Welfare Reducing?" Southern Economic Journal, 394-404.

Bandyopadhyay, Subhayu., 1996. "Growth, Welfare and Optimal Trade Taxes: A fallacy of Composition.” Journal of Development Economics, 50, 369-380.

Bandyopadhyay, Subhayu, 2001. "Illegal Immigration and Preferential Trade

Liberalization.” Working Paper, Department of Economics, West Virginia University.

Bean, Frank D., Thomas J. Espenshade, Michael J. White, and Robert F. Dymowski, 1990. "Post-IRCA Changes in the Volume and Composition of Undocumented Migration to the United States: An Assessment Based on Apprehensions Data." 111-158 in Undocumented Migration to the United States: IRCA and the Experience of the 1980s, edited by Frank D. Bean, Barry Edomonston, and Jeffrey S. Passel.

Bello, Walden, 1999 (December). "Should Developing Countries Push to Decommission The IMF.” International Forum on Globalization. 
http://www.ifg.org/walden_imf.html.

Bhagwati, J.N., Richard A. Brecher, and Tatsuo Hatta, 1983. "The Generalized Theory of Transfers and Welfare: Bilateral Transfers in a Multilateral World." American Economic Review, 73, 606-618.

Bond, Eric W. and Tain-Jy Chen, 1987. "The Welfare Effects of Illegal Immigration." Journal of International Economics, Vol. 23, 315-28.

Brannon, Jeffrey T., and William G. Lucker, 1988. "The Impact of Mexico's Economic Crisis on the Demographic Composition of the Maquiladora Labor Force.” Report prepared for the U.S. Department of Labor, and article in the Journal of Borderlands Studies, Vol. 4, No. 1, 39-70.

Bratsberg, Bernt, 1995. "Legal versus Illegal U.S. Immigration and Source Country Characteristics." Southern Economic Journal, Vol. 61, 715-727.

Brown, D.K., A.V. Deardorff, and R.M. Stern, 1992. "North American Integration.” The Economic Journal, Vol. 102, 1507-1518.

Bustamente, Jorge A., 1990. "Measuring the Floe of Undocumented Immigrants: Research Findings from the Zapata Canyon Project." in Undocumented Migration to the United States: IRCA and the Experience of the 1980s, edited by Frank D. Bean, Barry Edmonston, and Jeffrey S. Passel. Washington D.C.: Urban Institute, 211-226.

Calavita, Kitty, 1992. Inside the State: the Bracero Program, Immigration and the INS. New York: Routledge.

CEPR, 1992. "Is Bigger Better? The Economic of EC Enlargement." Monitoring European Integration, No. 3: London. 
CIEMEX-WEFA, 1992. Perspectivas Económicas de México. Bala Cynwyd, PA:

CIEMEX-WEFA (December).

Cuomo Commisssion on Competitiveness, 1992. America's Agenda: Building

Economic Strength. New York: M. E. Sharpe.

Dávila, Alberto and Rogelio Saenz, 1990. “The Effect of Maquiladora Employment on The Monthly Flow of Mexican Undocumented Immigration to the U.S., 19781982.” International Migration Review, Vol. 24, No. 1, 96-107.

Diakosavvas, Dimitris. and Pasquale L. Scandizzo, 1991. "Trends in the Terms of Trade of Primary Commodities, 1900-1982: The Controversy and its Origins." Economic Development and Cultural Change, 231-264.

Espenshade, Thomas J., 1990. "Undocumented Migration to the United States: Evidence from a Repeated Trials Model." in Undocumented Migration to the United States: IRCA and the Experience of the 1980s, edited by Frank D. Bean, Barry Edmonston, and Jeffrey S. Passel, Washington DC: Urban Institute, 159-182.

Espenshade, Thomas J., 1995. "Unauthorized Immigration to the United States.” Annual Review of Sociology, Vol. 21, 195-216.

Ethier, Wilfred J., 1986. "Illegal Immigration: The Host-Country Problem.” The American Economic Review, Vol. 76, No. 1, 56-71.

Feenstra, Robert C. and Gordon H. Hanson, 1995. "Foreign Investment, Outsourcing and Relative Wages.” National Bureau of Economic Research Working Paper 5121.

Feenstra, Robert C. and Gordon H. Hanson, 1997. "Foreign Direct Investment and Relative Wages: Evidence from Mexico's Maquiladoras.” Journal of International Economics, Vol. 42, 371-393. 
Fields, Gary S., 1982. "Place-to-Place Migration in Colombia.” Economic Development and Cultural Change, Vol. 30, No. 3, p. 539-558.

Greenwood, Michael J. and John .M. McDowell, 1986. "The Factor Market Consequences of U.S. Immigration.” Journal of Economic Literature, Vol. 24, $1738-1772$.

Hanson, Gordon H. and Antonio Spilimbergo, 1999a. "Illegal Imigration, Border Enforcement, and Relative Wages: Evidence from Apprehensions at the U.S.Mexico Border.” The American Economic Review, Vol. 89, 1337-1357.

Hanson, Gordon H. and Antonio Spilimbergo, 1999b. "Political Economy: Sectoral Shocks, and Border Enforcement." National Bureau of Economic Research Working Paper 7315.

Hanson, Gordon G., Raymond Robertson and Antonio Spilimbergo, 1999. "Does Border Enforcement Protect U.S. Workers from Illegal Immigration?” National Bureau of Economic Research Working Paper 7054.

Harris John R. and Michael P. Todaro, 1970. "Migration, Unemployment and Development: A Two-Sector Analysis." American Economic Review, Vol. 60, 126-142.

Harrison, L. E., 1992. “Those Huddled, Unskilled Masses: Is Our Immigration Policy Contributing to Our Economic Undoing?" The Washington Post, January 12, 1992.

Hill, John K. and James E. Pearce, 1990. “The Incidence of Sanctions against Employers of Illegal Aliens." Journal of Political Economy, Vol. 98, No. 1, 28-44.

Hinojosa-Ojeda, Raul and Sherman Robinson, 1991. "Labor issues in a North American 
Free Trade Area." In North American Free Trade: Assessing the Impact, edited by Nora Lustig, Barry Bosworth, and Robert Lawrence. Washington D.C.: The Brookings Institution.

Hinojosa-Ojeda, Raul and Robert McCleery, 1992. "U.S.-Mexico Interdependence,

Social Pacts and Policy Perspectives: A Computable General Equilibrium Approach." in U.S. Mexican Relations: Labor Market Interdependence, edited by Jorge Bustamante, Clark Reynolds, and Raul Hinojosa-Ojeda. Stanford, CA: Stanford Univ. Press.

House, William J. and Henry Rempel, 1980. “The Determination of Interregional Migration in Kenya.” World Development, Vol. 8, 25-35.

Huerta, Mario M. Carillo, 1990. The Impact of Maquiladoras on Migration in Mexico. Working Paper 51 (July). Washington: U.S. Commission for the Study of International Migration and Cooperative Economic Development.

Hufbauer, Gary C. and Jeffrey J. Schott, 1993. NAFTA, An Assesssment. Institute for International Economics, Washington D.C.

Hussain Abid, 1997 (August). "India's Fifty Years of Economic Development." India Perspectives. http://www.webspawner.com/users/IndustDevelA/.

Kennan, John and Raymond Riezman, 1988. "Do Big Countries Win Tariff Wars?” International Economic Review, Vol. 29, No.1, 81-85.

Koechlin, Timothy, and Mehrene Larudee, 1992. "The High Cost of NAFTA.” Challenge (September/October).

Krueger, Anne O., 1999. "Trade Creation and Trade Diversion Under NAFTA.” National Bureau of Economic Research Working Paper 7429. 
Lahiri, Sajal. and Pascalis Raimondos-Moller, 1997a. "Competition for Aid and Trade Policy." Journal of International Economics, Vol. 43, 369-385.

Lahiri, Sajal and Pascalis Raimondos-Moller, 1997b. "On the Tying Aid to Tariff Reform.” Journal of Development Economics, Vol. 54, No. 2, 479-491.

López, Ramón and Maurice Schiff, 1995. "Migration and the Skill Composition of the Labor Force, the Impact of Trade Liberalization in Developing Countries.” Policy Research Working Paper 1493, The World Bank: Washington D.C.

Markusen, James R. and Anthony J. Venables, 1997. “The Role of Multinational Firms in the Wage-Gap Debate." Review of International Economics, Vol. 5, No. 4, $435-451$.

Markusen, James R. and Anthony J. Venables, 1998. "Multinational firms and the New Trade Theory.” Journal of International Economics, Vol. 46, No. 2, 183-203. Markusen, James R. and Stephen Zahniser, 1997. "Liberalization and Incentives for Labor Migration: Theory With Applications to NAFTA.” National Bureau of Economic Research Working Paper 5121.

Martin, Philip L., 1993. Trade and Migration: NAFTA and Agriculture. Institute for International Economics, Washington D.C.

Panagariya, Arvind and Maurice Schiff, 1991. "Commodity Exports and Real Income in Africa: A Preliminary Analysis." in. Economic Reform in Sub-Saharan Africa, edited by Ajay Chhibber and Stanley Fischer. The World Bank: Washington D.C. Panagariya, Arvind and Maurice Schiff, 1995. “Optimum and Revenue Maximizing Trade Taxes in a Multicountry Framework." Revista de Analisis Economico, Vol. 10, No. 1, 19-35. 
Ravenstein, E. G., 1889. “The Laws of Migration.” Journal of the Royal Statistical Society, No. 52, London.

Roberts, Jorge Sebastian, 2001 (May). "The Reasons for Mexico's Trade Liberalization.” Department of Economics, University of Washington, Seattle. http://www.econ.washington.edu/features/roberts/roberts_paper.pdf.

Robinson, Sherman, Mary Burfisher, Raúl Hinojosa_Ojeda, and Karen Thierfeldar, 1992. "Agricultural Policies and Migration in a U.S.-Mexico Free Trade Area: A Computable General Equilibrium Analysis." Berkeley, CA: Department of Agriculture and Resource Economics, Division of Agriculture and Natural Resources, University of California at Berkeley, Working Paper 617 (October).

Rodrik, Dani, 1995. "Trade and Industrial Policy Reform." in Handbook of Development Economics, edited by Jere Behrman and T.N. Srinivasan, Vol. III, Chapter 45, 2925-2982. Elsevier.

Samuelson, Paul.A. 1947. Foundations of Economic Analysis. Cambridge: Harvard University Press.

Schwanen, Daniel, 2001. "Trade Liberalization and Inequality in Canada in the 1990s." Institute for Research on Public Policy. http://www.irpp.org/miscpubs/archive/repsp0501/schwanen.pdf.

Schiff, Maurice, 1994. "How Trade, Aid, and Remittances Affect International Migration.” Policy Research Working Paper 1376. The World Bank: Washington D.C.

Seligson, Mitchell and Edward Williams, 1981. Maquiladoras and Migration: A Study of 
Workers in the Mexican-United States Border Industrialization Program. Austin: University of Texas, Mexico-United States Border Research Program.

Simon, Julian, 1981. The Ultimate Resource. Princeton, NJ: Princeton University Press.

Sklair, Leslie, 1989. Assembling for Development: The Maquila Industry in Mexico and the United States. Boston and London: Unwin Hyman.

Sorensen, Elaine, Frank D. Bean, Leighton Ku, Wendy Zimmermann, 1992. Immigrant Categories and the U.S. Job Market: Do They Make a Difference? Urban Institute Report 92-1, Urban Institute Press.

U.S. Immigration and Naturalization Service. Statistical Yearbook of the Immigration and Naturalization Service.

Walsh, Denny, 1999 (April). "Valley Growers Guilty: Admits Farm Used Illgela Workers." The Sacramento Bee.

Weintraub, Sidney, 1984. Free Trade Between Mexico and the United States? Washington D.C.: Brookings Institution.

White, Michael J., Frank D. Bean and Thomas J. Espenshade, 1990. “The U.S. 1986 Immigration reform and Control Act and Undocumented Migration to the United States." Population Research and Policy Review, Vol. 9, 93-116.

Wooldridge, Jeffrey M., 2002. Econometric Analysis of Cross Section and Panel Data. Publisher: Massachusetts Institute of Technology.

World Trade Organization, 1999. Trade Policy Reviews, United States: July, 1999. http://www.wto.org/english/tratop_e/tpr_e/tp108_e.htm. 1998. Trade Policy Reviews, India: April, 1998. http://www.wto.org/english/tratop_e/tpr_e/tp71_e.htm. 
1996. Trade Policy Reviews, El Salvador: November, 1996.

http://www.wto.org/english/tratop_e/tpr_e/tp52_e.htm.

1995. Trade Policy Reviews, European Union: July, 1995.

http://www.wto.org/english/tratop_e/tpr_e/tp10_e.htm.

Yilmaz, K., 1999. “Optimal Export Taxes in a Multi-Country Framework.” Journal of Development Economics, Vol. 60, 439-465.

Zang, Dongsheng, 2001. "Seeking Transparency in Antidumping Actions through Procedural Review: The GATT/WTO Jurisprudence and its Implications for China (Part 1)." Perspectives, Vol. 2. No. 5. http://www.oycf.org/Perspectives/11_043001/seeking_transparency_in_antidump htm.

Zimmermann, Klaus F., 1993. "Immigration Policies in Europe: An Overview.” in Migration: A Challenge for Europe, edited by Horst Siebert. Tubingen: J.C.B. Mohr (Paul Siebeck).

Zimmermann, Klaus F., 1996. “European Migration: Push and Pull.” International Regional Science Review, Vol. 19, No.'s 1 \& 2, 95-128. 